Supporting Information

\title{
Multikilogram per Hour Continuous \\ Photochemical Benzylic Brominations Applying a Smart Dimensioning Scale-up Strategy
}

\author{
Alexander Steiner, ${ }^{\dagger, t}$ Philippe M. C. Roth,$^{\S}$ Franz J. Strauss, " Guillaume Gauron, ${ }^{\S}$ Günter \\ Tekautz," Marc Winter, ${ }^{\S}$ Jason D. Williams, *,+, C. Oliver Kappe ${ }^{*,+,+}$
}




\section{Contents}

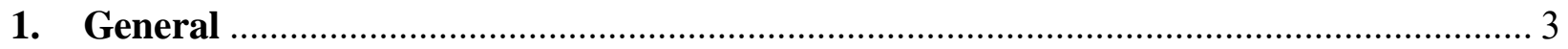

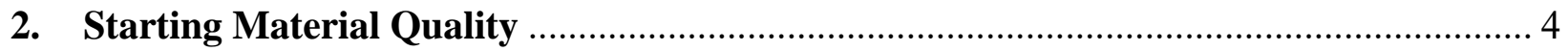

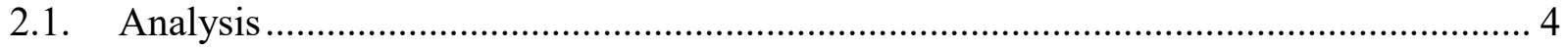

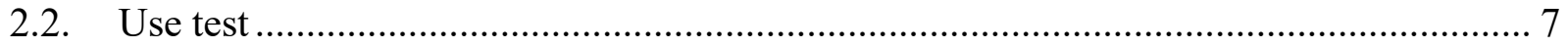

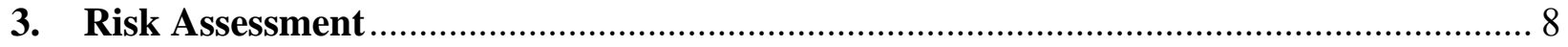

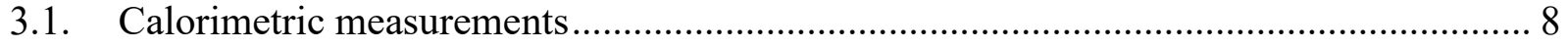

3.2. Reaction Heat Calculations ………………….................................................... 15

3.3. Detailed Process Risk Assessment........................................................................ 17

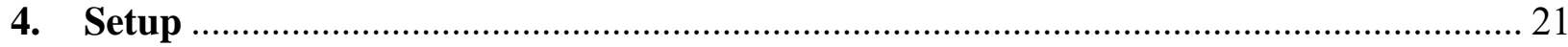

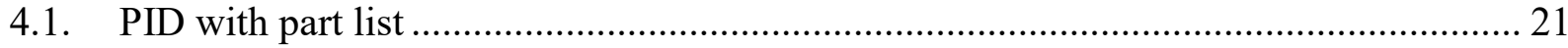

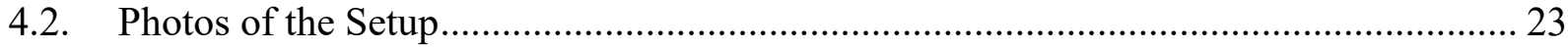

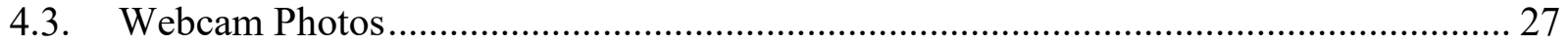

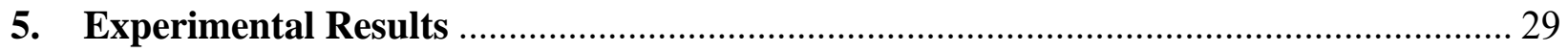

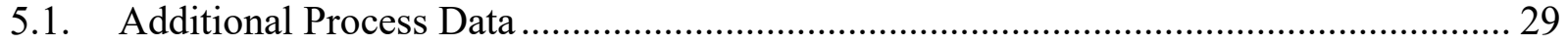

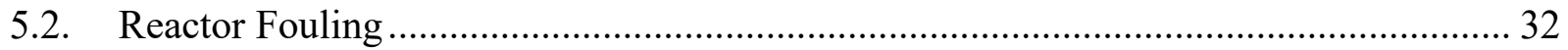

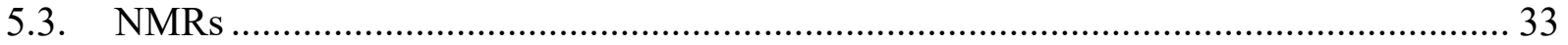

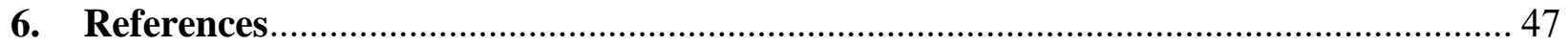




\section{General}

2,6-Dichlorotoluene was purchased from TCI (Catalog \#D0422, batch \#HNDSJOI, stated purity $>99.0 \%$ ), sodium bromate (Catalog \#8.45066.1000, batch \#S7485966 933, stated purity $\geq 99.0 \%$ ) and $\mathrm{HBr}$ (Catalog \#1.00304.2500, batch \#B1692904 920, stated concentration 47\%) from Merck, sodium thiosulfate pentahydrate from Roth (Catalog \#T109.3, batch \#030290641, stated purity $\geq 99 \%$ ). Sodium bromate and sodium thiosulfate solutions were prepared in 2 and 5 L batches, by dissolving $332 \mathrm{~g} \mathrm{NaBrO} 3$ or $655 \mathrm{~g} \mathrm{Na}_{2} \mathrm{~S}_{2} \mathrm{O}_{3} \cdot 5 \mathrm{H}_{2} \mathrm{O}$ per liter of solution. To facilitate the dissolution process, the flasks were put in a water bath $\left(\sim 40^{\circ} \mathrm{C}\right)$. $\mathrm{HBr}$ and $\mathrm{DCT}$ were used without further treatment.

1H NMR spectra were recorded using a low field benchtop NMR (Magritek, Spinsolve Ultra, $43 \mathrm{MHz})$.

HPLC analysis was carried out on a C18 reversed-phase analytical column $(150 \times 4.6 \mathrm{~mm}$, particle size $5 \mu \mathrm{m}$ ) at $37{ }^{\circ} \mathrm{C}$ using mobile phases: A (water/MeCN 90:10 (v/v) $+0.1 \%$ TFA) and $\mathrm{B}(\mathrm{MeCN}+0.1 \% \mathrm{TFA})$ at a flow rate of $1.5 \mathrm{~mL} \mathrm{~min}^{-1}$. The following gradient was applied: linear increase from $30 \%$ to $100 \%$ B over 13 minutes.

GC-FID analysis was performed on a Shimadzu GC FID 2030 with a flame ionization detector, using a RTX -5MS column $(30 \mathrm{~m} \times 0.25 \mathrm{~mm}$ ID $\times 0.25 \mu \mathrm{m})$ and helium as carrier gas $\left(40 \mathrm{~cm} \mathrm{sec}^{-}\right.$ ${ }^{1}$ linear velocity). The injector temperature was set at $280{ }^{\circ} \mathrm{C}$. Within the $\mathrm{GC}$ oven, after $1 \mathrm{~min}$ at $50{ }^{\circ} \mathrm{C}$, the temperature was increased by $25^{\circ} \mathrm{C} \mathrm{min}$ m $^{-1}$ to $300{ }^{\circ} \mathrm{C}$ and kept constant at $300{ }^{\circ} \mathrm{C}$ for $4 \mathrm{~min}$. The detector gases used for flame ionization were hydrogen and synthetic air (5.0 quality).

ICP-MS analysis was performed on an Agilent 7700x instrument. $200 \mu \mathrm{L}$ of the sample were digested using $5 \mathrm{~mL} \mathrm{HNO}_{3}$ and heating in a MLS UltraClave (ramp $30 \mathrm{~min}$ to $250{ }^{\circ} \mathrm{C}$, hold $30 \mathrm{~min}$ at $250{ }^{\circ} \mathrm{C}$ ) and subsequently diluted for the measurement. 


\section{Starting Material Quality}

\subsection{Analysis}

The following two samples of the substrate 2,6-dichlorotoluene (CAS Number 118-69-4) are compared:

\begin{tabular}{cccc}
\hline & Supplier & Batch $\#$ & $\begin{array}{c}\text { Observed } \\
\text { conversion }^{\text {a }}\end{array}$ \\
\hline Sample 1 & TCI & HNDSJOI & $>90 \%$ \\
Sample 2 & AKScientific & LC27600 & $10-20 \%$ \\
\hline
\end{tabular}

${ }^{\mathrm{a}} \mathrm{Lab}$ reactor: $\mathrm{t}_{\mathrm{R}}=15 \mathrm{sec}, 1.1$ equiv. $\mathrm{Br}_{2}, 55^{\circ} \mathrm{C}$.

Visual comparison:

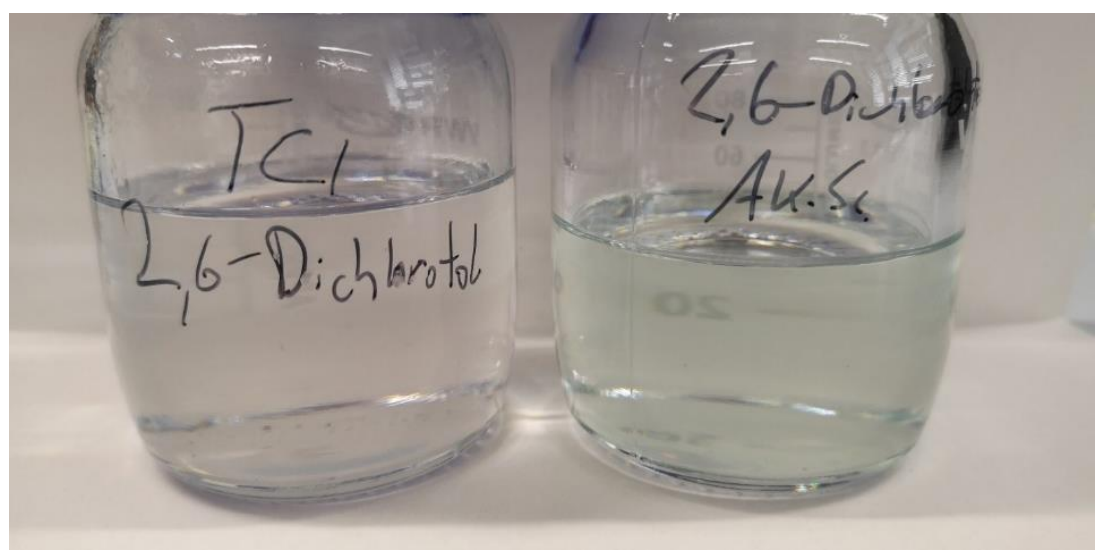

Figure S1. Visual comparison of the samples 1 (left) and 2 (right). The substrate on the left was colorless, while the one on the right was a pale blue color.

ICP-MS: ICP-MS measurements showed no difference in metal content in either of the two samples. In both cases, the metal content was lower than the detection limit for all screened metals. 
HPLC: No impurities could be detected on the HPLC, in sample 1 (Figure S2a). Two peaks accounting for $1.1 \mathrm{area} \%(5.12 \mathrm{~min})$ and $0.3 \mathrm{area} \%(6.46 \mathrm{~min})$ at $254 \mathrm{~nm}$ were found in sample 2 (Figure S2b).

\section{a}

MAU

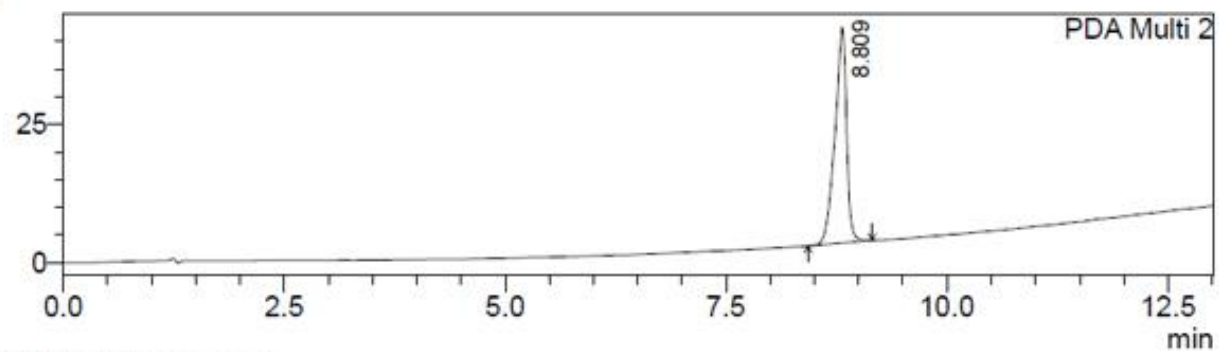

1 PDA Multi $2 / 254 \mathrm{~nm}, 4 \mathrm{~nm}$

b

MAU

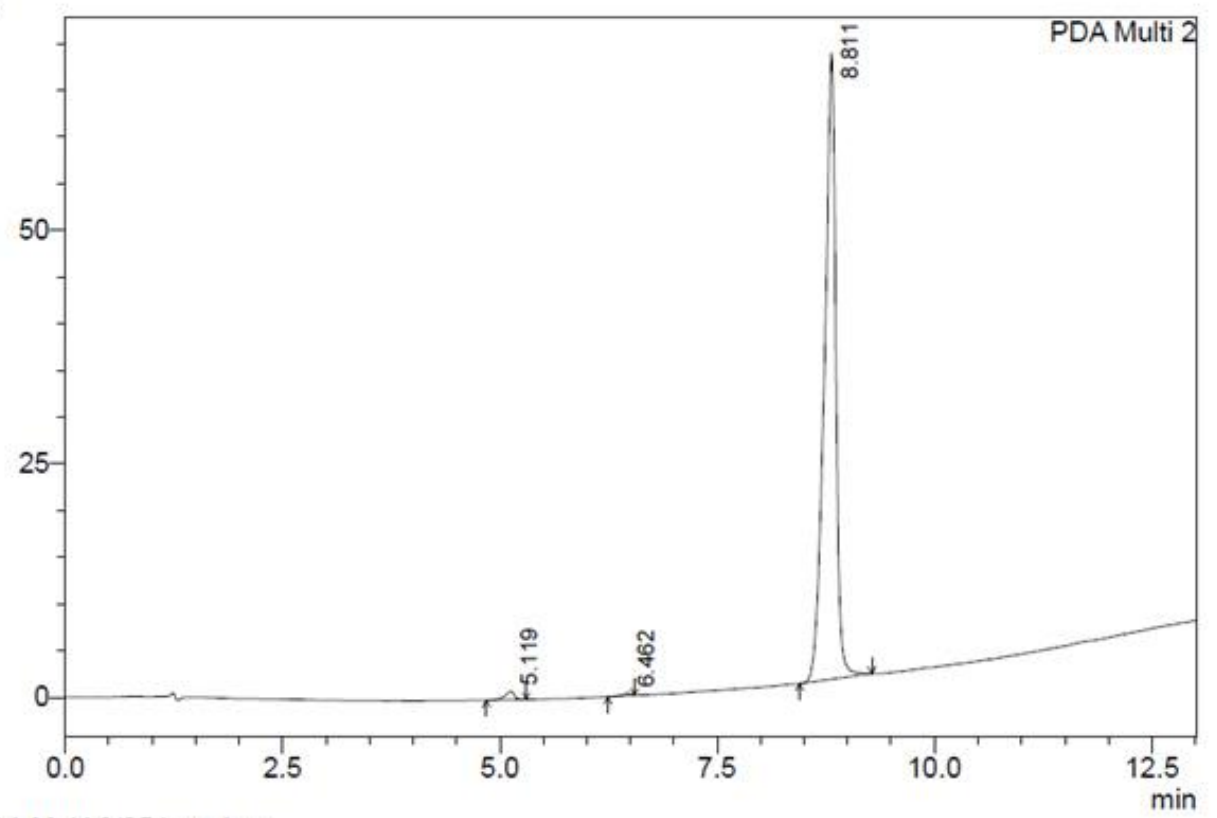

1 PDA Multi $2 / 254 \mathrm{~nm}, 4 \mathrm{~nm}$

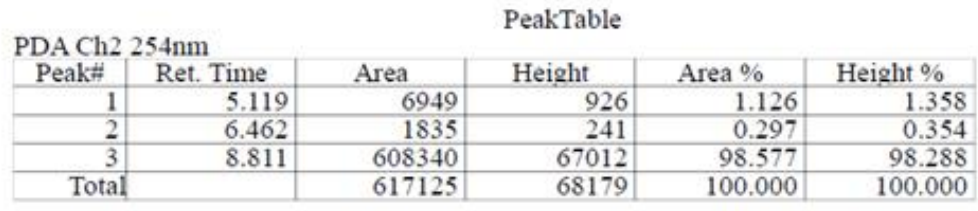

Figure S2. HPLC analysis, a) sample 1; b) sample 2. 
GC-FID: The impurity at 5.6 minutes was found in both samples, accounting for 0.05 area $\%$. However, in sample 2 further impurities were found, the most significant one being the shoulder at 5.4 minutes $(\sim 0.15$ area\%).

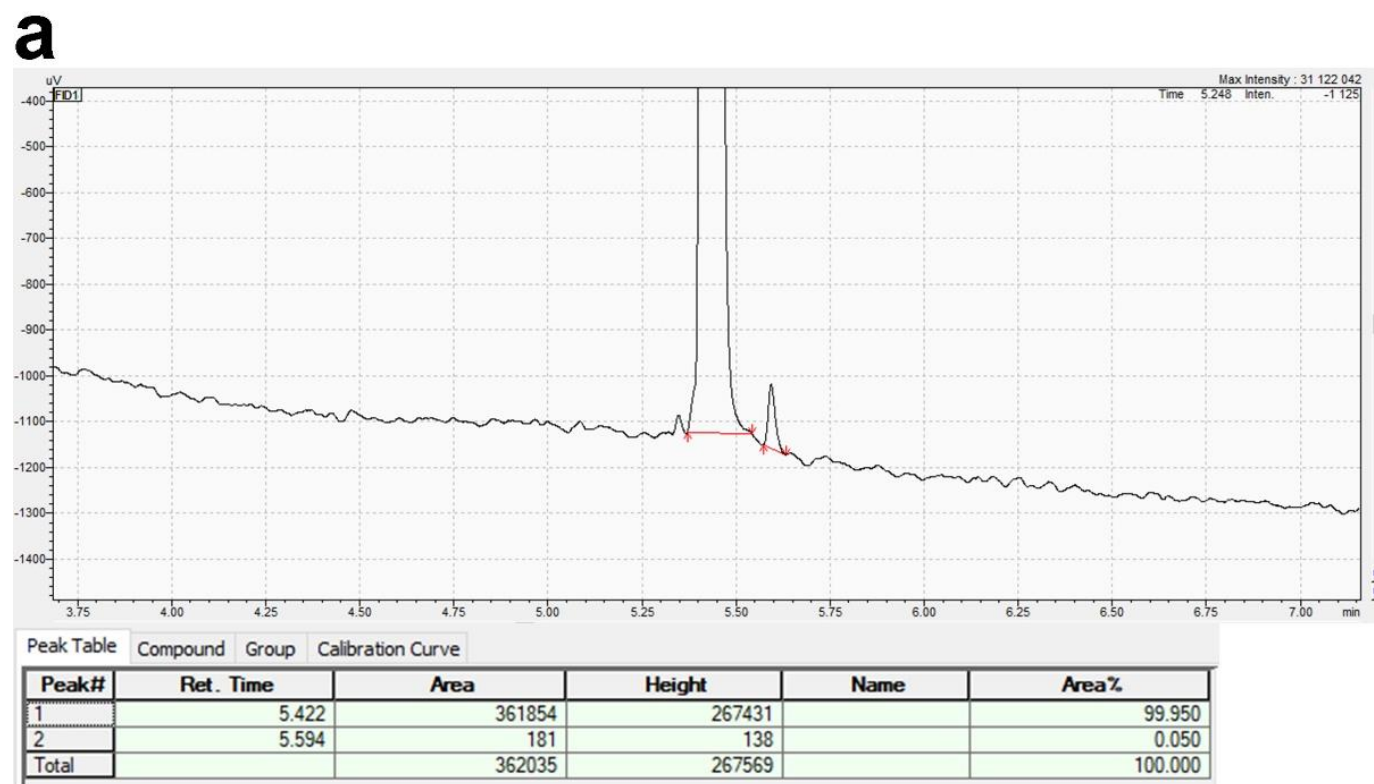

\section{b}

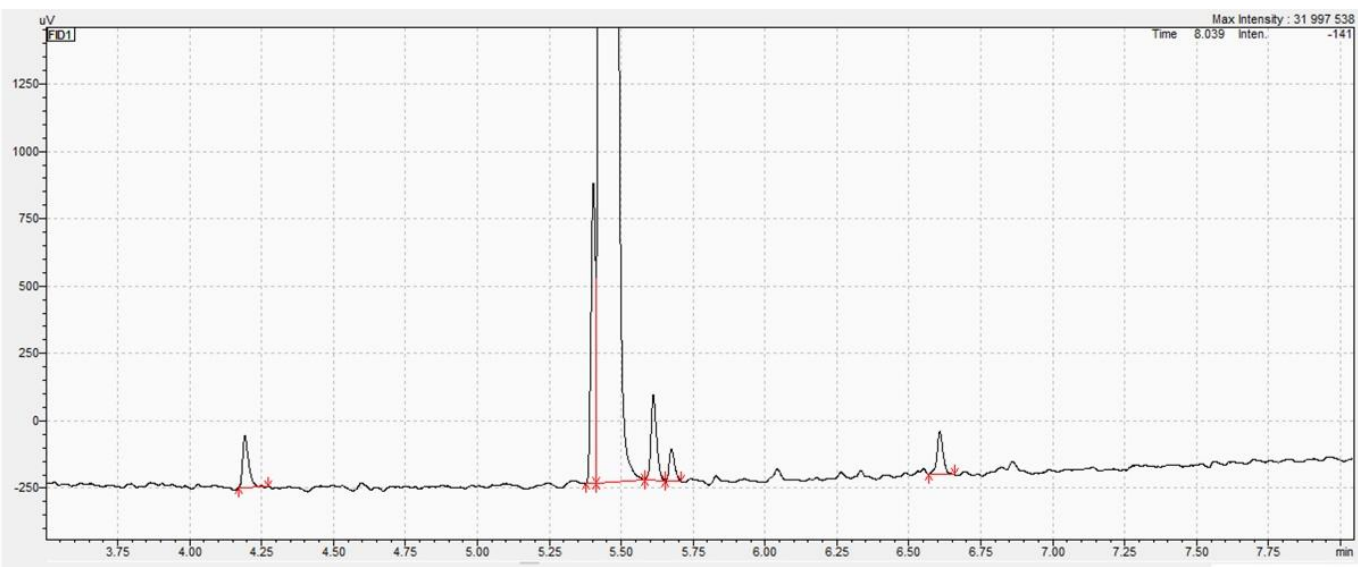

Peak Table Compound Group Calibration Curve
\begin{tabular}{|l|r|r|r|r|r|}
\hline Peak\# & \multicolumn{1}{|c|}{ Ret. Time } & \multicolumn{1}{|c|}{ Area } & \multicolumn{1}{c|}{ Height } & Name & \multicolumn{1}{c|}{ Area\% } \\
\hline 1 & 4.193 & 276 & 189 & 0.034 \\
\hline 2 & 5.403 & 1219 & 1088 & 0.150 \\
\hline 3 & 5.444 & 807678 & 594172 & 99.717 \\
\hline 4 & 5.612 & 417 & 310 & 0.051 \\
\hline 5 & 5.675 & 152 & 112 & 0.019 \\
\hline 6 & 6.608 & 230 & 155 & 0.028 \\
\hline Total & & 809972 & 596027 & 100.000 \\
\hline
\end{tabular}

Figure S3. GC-FID analysis, a) sample 1; b) sample 2. 


\subsection{Use test}

To rule out issues with the starting material quality, a use test was performed in the Corning ${ }^{\circledR}$ Advanced-Flow ${ }^{\mathrm{TM}}$ Lab Photo Reactor. Using the previous reaction setup, ${ }^{\mathrm{S} 1}$ the results listed in Table S1 were obtained. These are in agreement with the previously reported data. ${ }^{\mathrm{S} 1}$

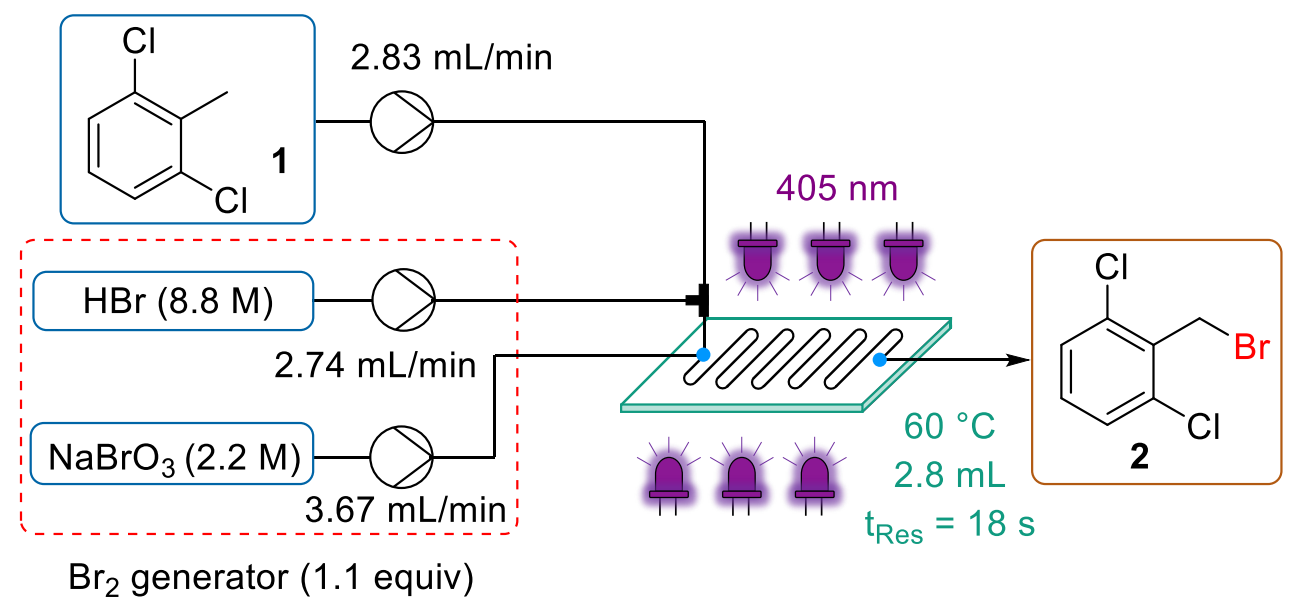

Figure S4. Schematic representation of the set up of the lab scale reactor. Flowrates correspond to Table S1 entry 1.

Table S1. Results of the use test of the material batches for large scale experiments

\begin{tabular}{ccccc}
\hline Entry & Temperature $\left[{ }^{\circ} \mathrm{C}\right]$ & Residence time [s] & Equivalents Br 2 & $\begin{array}{c}\text { Assay Yield } \\
{[\%]^{\mathrm{a}}}\end{array}$ \\
\hline 1 & 60 & 18 & 1.1 & 93 \\
2 & 60 & 18 & 1.2 & 97 \\
3 & 60 & 20 & 1.1 & 94 \\
4 & 60 & 20 & 1.1 & 97 \\
5 & 60 & 15 & 1.2 & 64
\end{tabular}

${ }^{\mathrm{a}}$ Determined by ${ }^{1} \mathrm{H}$ benchtop NMR as the ratio of starting material 1 vs product $\mathbf{2}$ benzylic signals. 


\section{Risk Assessment}

\subsection{Calorimetric measurements}

Calorimetric measurements were performed using a THT $\mu \mathrm{RC}$ microcalorimeter in isothermal titration mode. Both the measurement and reference vials in the calorimeter were charged with $1 \mathrm{~mL}$ of solution $\mathbf{A}$ and kept at a constant temperature $\mathbf{T}$. A disposable $1 \mathrm{~mL}$ syringe (used due to compatibility issues with other syringe materials) was filled with solution $\mathbf{B}$. After the temperature stabilized a portion of $41.5 \mu \mathrm{L}$ of solution $\mathbf{B}$ was injected and the change in heating/cooling power was recorded as a function of time. A series of 5 separate injections was used for the reaction heat

determination. For the use of the disposable syringe, a calibration factor had to be determined, to ensure accuracy. 


\section{Calibration}

$41.5 \mu \mathrm{L}$ portions of a $0.15 \mathrm{M} \mathrm{HNO}_{3}$ solution $(6.3 \mu \mathrm{mol}$ per injection) were injected into a $0.5 \mathrm{M}$ $\mathrm{NaOH}$ solution at $25^{\circ} \mathrm{C}$. Integration of the peaks gives an average compensation energy of 391 $\mathrm{mJ}$, corresponding to an exotherm of $-61.9 \mathrm{~kJ} \mathrm{~mol}^{-1}$. Using a literature value for the heat of neutralization $\left(-57.7 \mathrm{~kJ} \mathrm{~mol}^{-1}\right)$, a calibration factor of 0.93 was determined.

Table S2. Calibration data for the disposable syringe setup in the calorimeter.

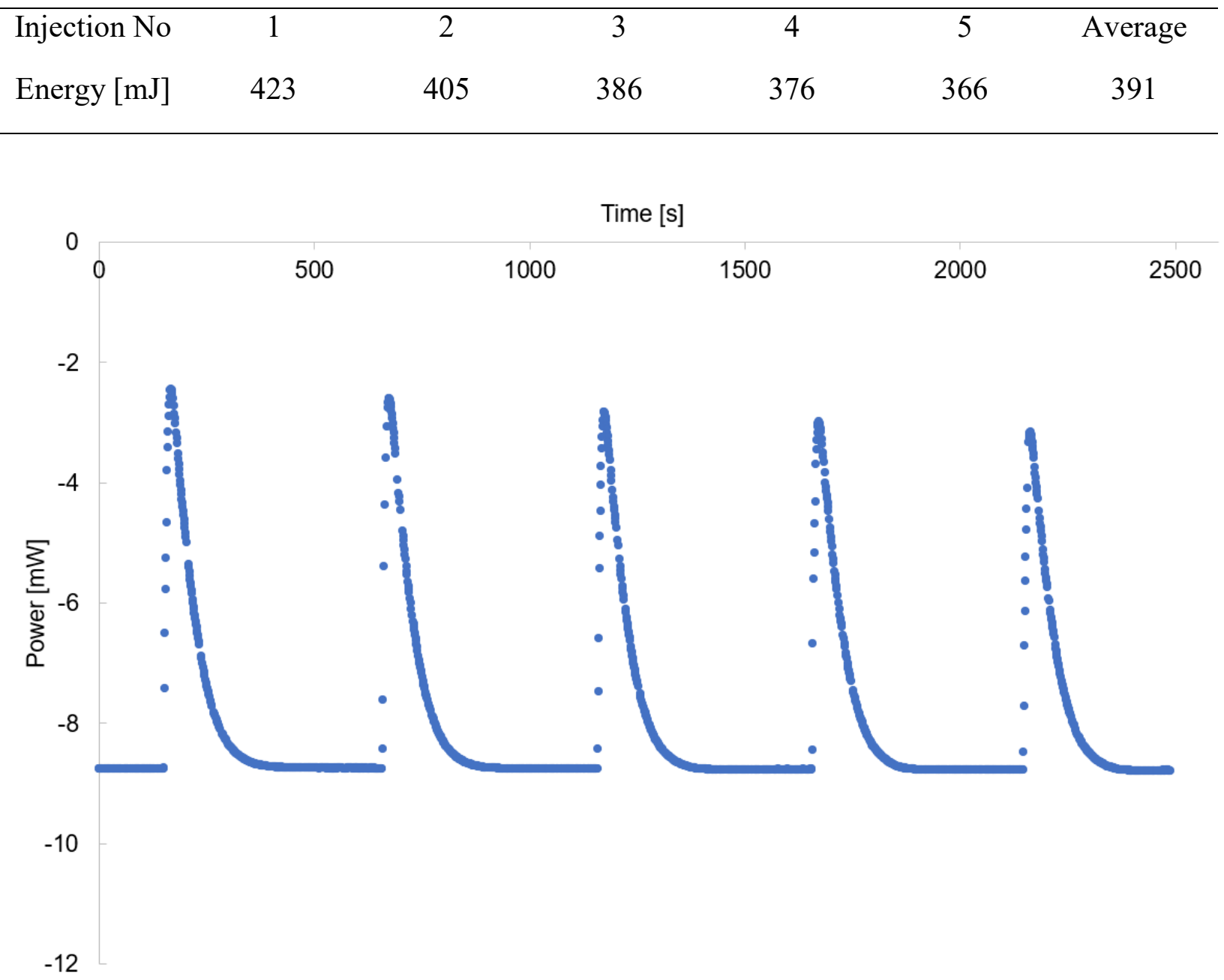

Figure S5. Calibration of the calorimeter using the disposable syringe. 


\section{Br2 formation (Manuscript Table 1 entry 1)}

$41.5 \mu \mathrm{L}$ portions of a $0.1 \mathrm{M} \mathrm{NaBrO}_{3}$ solution $(4.15 \mu \mathrm{mol}$ per injection) were injected into a $0.5 \mathrm{M} \mathrm{HBr}$ solution at $25{ }^{\circ} \mathrm{C}$. Integration of the peaks gave an average energy of $870 \mathrm{~mJ}$, corresponding to an exotherm of $-69.9 \mathrm{~kJ} \mathrm{~mol}^{-1}$ of $\mathrm{Br}_{2}$. Correction with the calibration factor of 0.93 results in an exotherm of $-65.1 \mathrm{~kJ} \mathrm{~mol}^{-1}$ of $\mathrm{Br}_{2}$.

Table S3. Calorimetry: Bromine formation.

$\begin{array}{lcccccc}\text { Injection No } & 1 & 2 & 3 & 4 & 5 & \text { Average } \\ \text { Energy }[\mathrm{mJ}] & 820 & 882 & 883 & 881 & 879 & 869\end{array}$

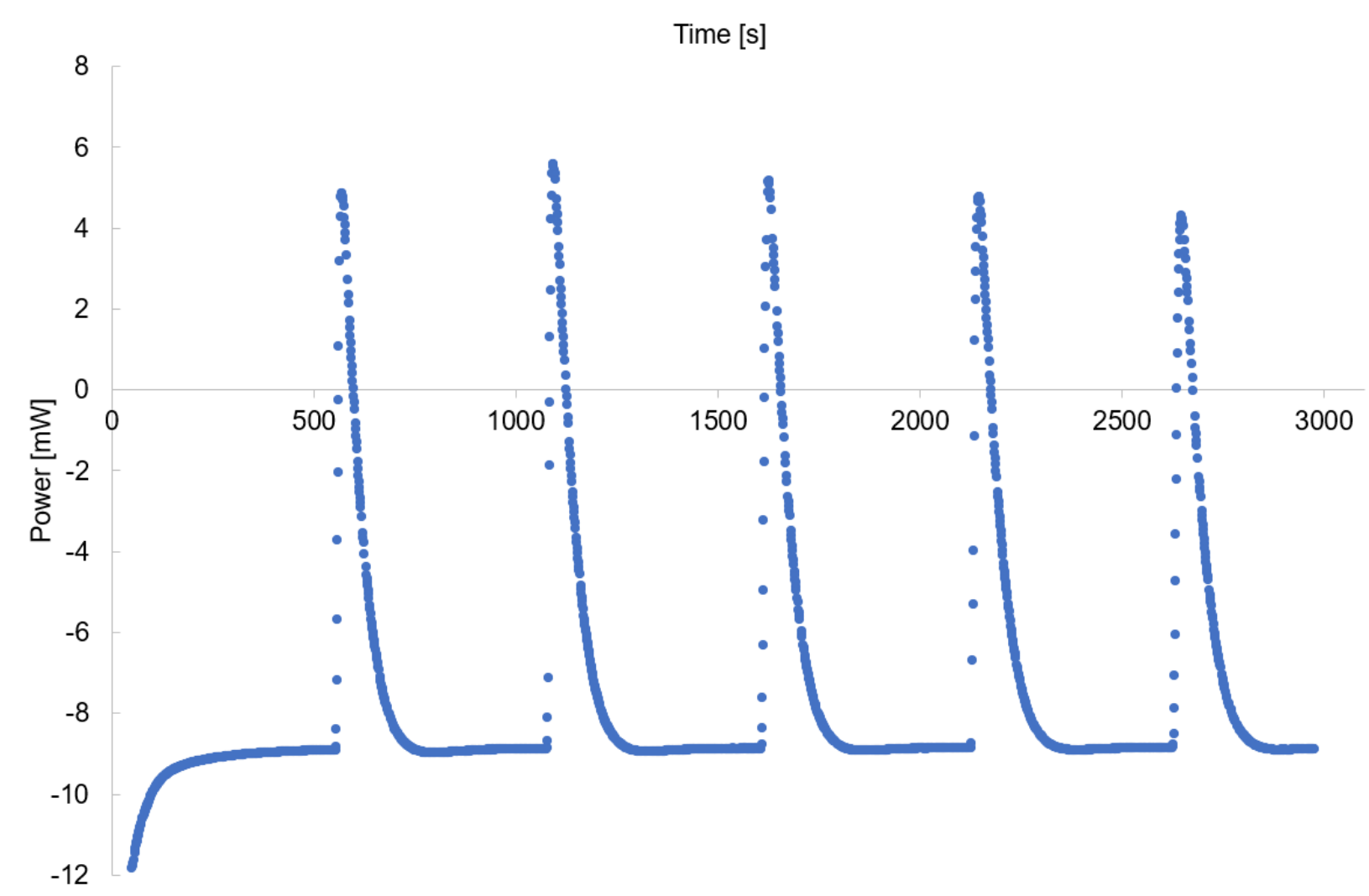

Figure S6. Calorimetry: Bromine formation. 


\section{Bromine quench with sodium thiosulfate (Manuscript Table 1 entry 3)}

$41.5 \mu \mathrm{L}$ portions of a $0.09 \mathrm{M} \mathrm{Br}_{2}$ solution (3.62 $\mu \mathrm{mol}$ per injection) were injected into a $0.5 \mathrm{M}$ $\mathrm{Na}_{2} \mathrm{~S}_{2} \mathrm{O}_{3}$ solution at $25{ }^{\circ} \mathrm{C}$. Integration of the peaks gives an average energy of $447 \mathrm{~mJ}$,

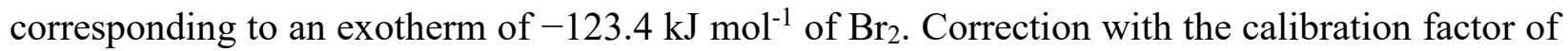
0.93 results in an exotherm of $-115.0 \mathrm{~kJ} \mathrm{~mol}^{-1}$ of $\mathrm{Br}_{2}$.

Table S4. Calorimetry: Bromine quench.

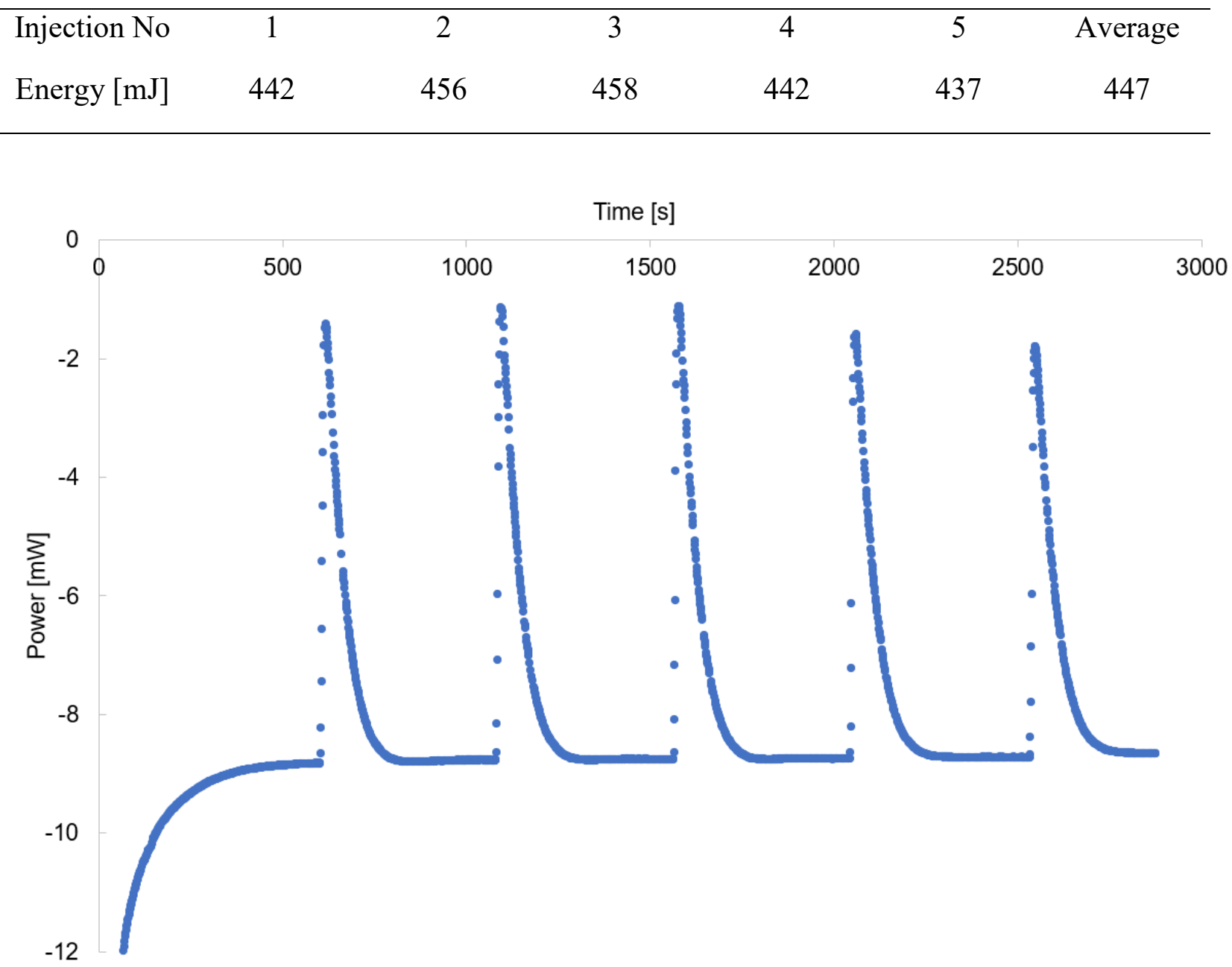

Figure S7. Calorimetry: Bromine quench. 


\section{Sodium thiosulfate and $\mathrm{HBr}$ (Manuscript Table 1 entry 4)}

$41.5 \mu \mathrm{L}$ portions of a $2.64 \mathrm{M} \mathrm{Na}_{2} \mathrm{~S}_{2} \mathrm{O}_{3}$ solution (109 $\mu \mathrm{mol}$ per injection) were injected into a $47 \% \mathrm{HBr}$ solution at $25^{\circ} \mathrm{C}$. The observed peaks decrease with each injection, so the measurement was stopped after the fourth. This is proposed to be caused by the formation of large amounts of sulfur in the test vial, due to the concentrated solutions used. A pressure sensor attached to the vial showed no increase in pressure during the measurements (implying no gas formation). To estimate the maximum possible exotherm from this reaction, only the first (most major) peak was integrated. The compensation energy of $2344 \mathrm{~mJ}$ corresponds to an exotherm of $-21.4 \mathrm{~kJ} \mathrm{~mol}^{-1}$ of $\mathrm{Na}_{2} \mathrm{~S}_{2} \mathrm{O}_{3}$. Correction with the calibration factor of 0.93 results in an exotherm of $-20.0 \mathrm{~kJ} \mathrm{~mol}^{-1}$ of $\mathrm{Na}_{2} \mathrm{~S}_{2} \mathrm{O}_{3}$.

Table S5. Calorimetry: Thiosulfate and HBr.

\begin{tabular}{lcccccc}
\hline Injection No & 1 & 2 & 3 & 4 & 5 & Average \\
Energy $[\mathrm{mJ}]$ & 2344 & n.d. & n.d. & n.d. & n.d. & n.d. \\
\hline
\end{tabular}

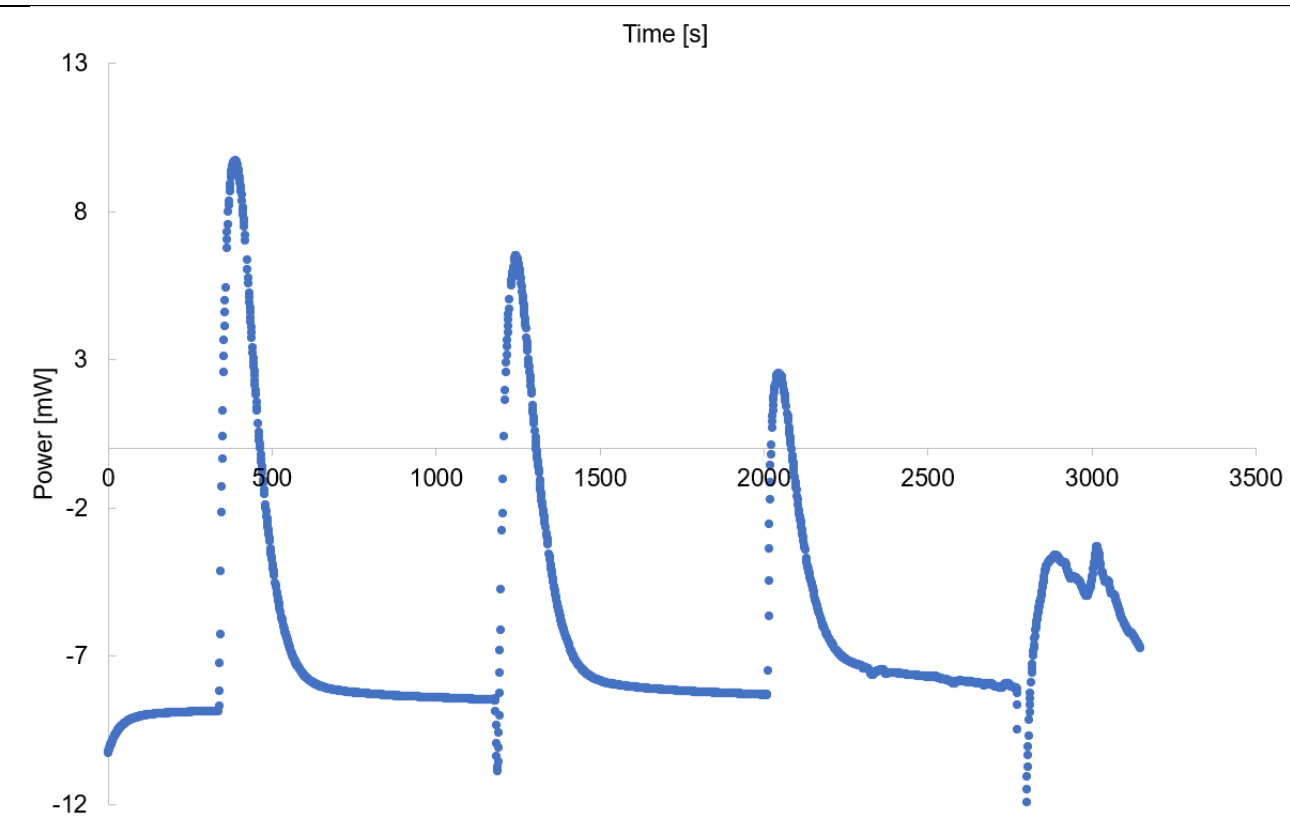

Figure S8. Calorimetry: Thiosulfate and $\mathrm{HBr}$. 


\section{Sodium bromate and sodium thiosulfate (Manuscript Table 1 entry 5)}

$41.5 \mu \mathrm{L}$ portions of a $2.2 \mathrm{M} \mathrm{NaBrO}_{3}$ solution (91 $\mu$ mol per injection) were injected into a $2.64 \mathrm{M}$ $\mathrm{Na}_{2} \mathrm{~S}_{2} \mathrm{O}_{3}$ solution at $25{ }^{\circ} \mathrm{C}$. Since the peaks decreased significantly over the course of five injections, only the first peak was integrated for the estimation of the maximum exotherm. The obtained energy of $32.1 \mathrm{~mJ}$, corresponds to an exotherm of $-0.4 \mathrm{~kJ} \mathrm{~mol}^{-1}$ of $\mathrm{NaBrO}_{3}$.

Table S6. Calorimetry: Sodium thiosulfate and sodium bromate.

\begin{tabular}{lcccccc}
\hline Injection No & 1 & 2 & 3 & 4 & 5 & Average \\
Energy $[\mathrm{mJ}]$ & 32.1 & n.d. & n.d. & n.d. & n.d. & n.d. \\
\hline
\end{tabular}

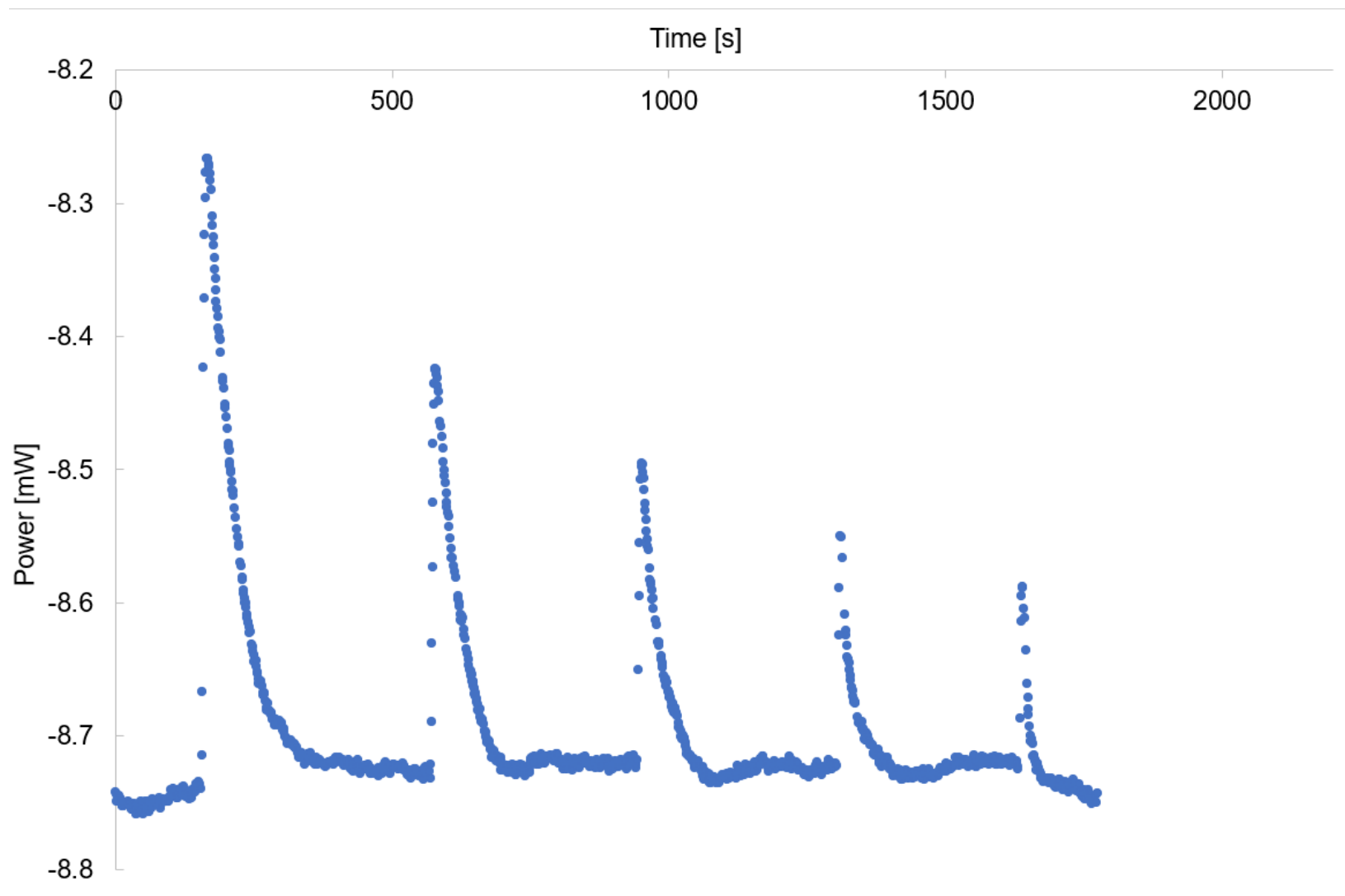

Figure S9. Calorimetry: Thiosulfate and bromate. 


\section{2,6-Dichlorotoluene and sodium bromate (Manuscript Table 1 entry 6)}

$41.5 \mu \mathrm{L}$ portions of neat 2,6-dichlorotoluene $1(323 \mu \mathrm{mol}$ per injection) were injected into a 2.2 $\mathrm{M} \mathrm{NaBrO}_{3}$ solution at $25^{\circ} \mathrm{C}$. No significant exotherm was observed.

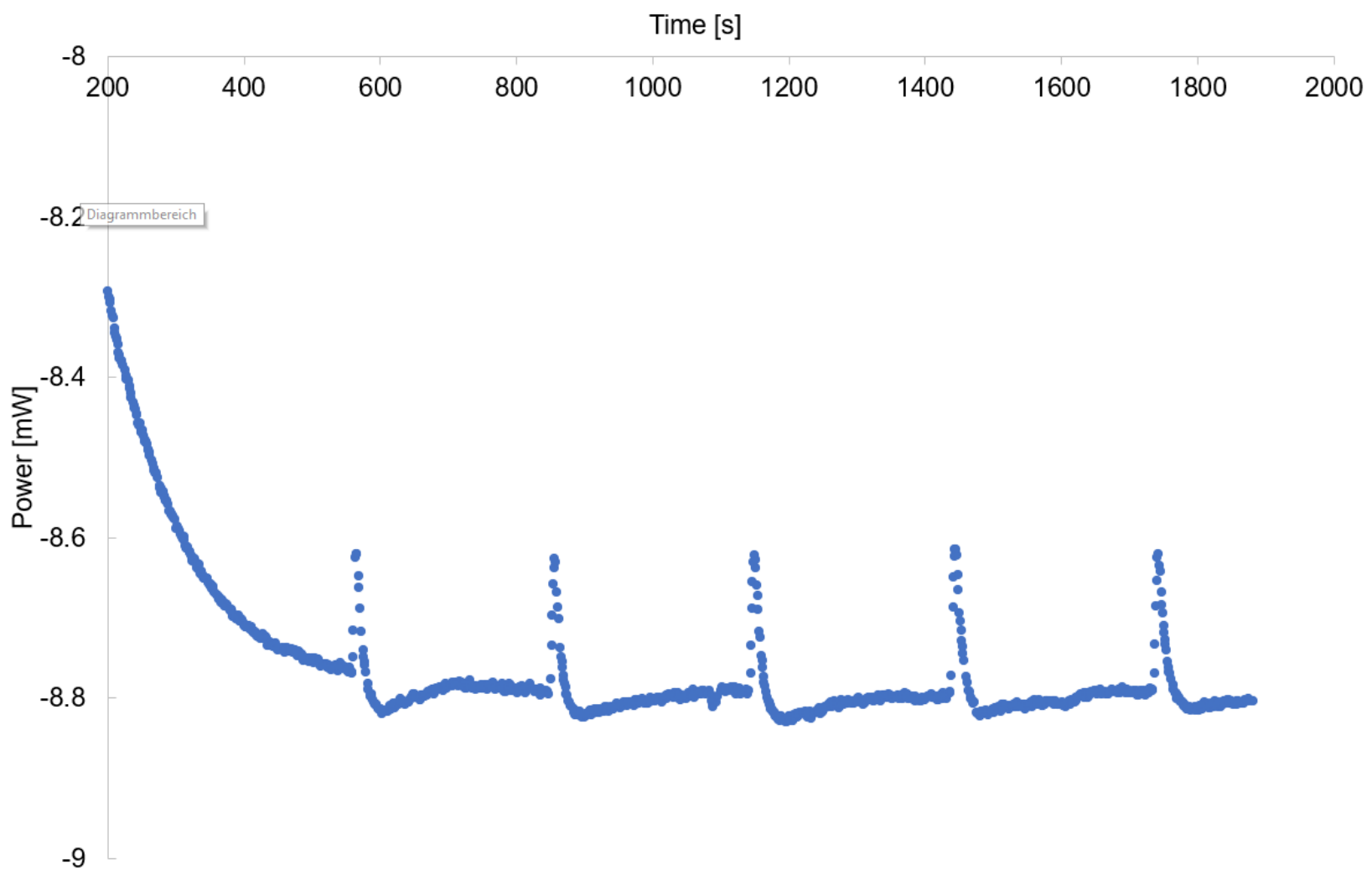

Figure S10. Calorimetry: 2,6-Dichlorotoluene 1 and $\mathrm{NaBrO}_{3}$. 


\subsection{Reaction Heat Calculations}

The reaction enthalpies $\Delta H_{r}^{0}$ were calculated as the difference of the standard formation enthalpies $\Delta H_{f}^{0}$ of the products and the reactants. Standard formation enthalpies were taken from the Handbook of Chemistry and Physics. ${ }^{\mathrm{S} 2}$

Bromine formation (Manuscript Table 1 entry 1)

\begin{tabular}{|c|c|c|c|}
\hline Reaction & $\mathrm{BrO}_{3}^{-}{ }_{(\mathrm{aq})}+6 \mathrm{HBr}_{(\mathrm{aq})}$ & $\rightarrow$ & $3 \mathrm{Br}_{2(\mathrm{aq})}+3 \mathrm{H}_{2} \mathrm{O}_{(\mathrm{l})}+\mathrm{Br}^{-}{ }_{(\mathrm{aq})}$ \\
\hline$\Delta H_{f}^{0}\left[\mathrm{kCal} \mathrm{mol}{ }^{-1}\right]$ & $-16.03+6 \times(-29.05)$ & & $3 \times(-0.62)+3 \times(-68.315)-29.05$ \\
\hline
\end{tabular}

$\Delta H_{r}^{0}=-235.86-(-190.33)=-45.5 \mathrm{kCal}$ per reaction

Therefore, the reaction enthalpy per mole of $\mathrm{Br}_{2}$ is $-15.2 \mathrm{kCal} \mathrm{mol}^{-1}\left(-63.5 \mathrm{~kJ} \mathrm{~mol}^{-1}\right)$. 


\section{Bromine quench (Table 1 entry 3)}

\begin{tabular}{cccc}
\hline Reaction & $5 \mathrm{H}_{2} \mathrm{O}_{(\mathrm{l})}+4 \mathrm{Br}_{2(\mathrm{aq})}+\mathrm{S}_{2} \mathrm{O}_{3^{2-}}{ }_{(\mathrm{aq})}$ & $\rightarrow$ & $8 \mathrm{Br}^{-}{ }_{(\mathrm{aq})}+2 \mathrm{SO}_{4}{ }^{2-}{ }_{(\mathrm{aq})}+10 \mathrm{H}^{+}{ }_{(\mathrm{aq})}$ \\
$\Delta H_{f}^{0}\left[\mathrm{kCal} \mathrm{mol}^{-1}\right]$ & $5 \times(-68.315)+4 \times(-0.62)-155.9$ & & $8 \times(-29.05)+2 \times(-217.32)+0$ \\
\hline \multicolumn{2}{l}{} &
\end{tabular}

Therefore, the reaction enthalpy per mole of $\mathrm{Br}_{2}$ is $-41.8 \mathrm{kCal} \mathrm{mol}^{-1}\left(-174.9 \mathrm{~kJ} \mathrm{~mol}^{-1}\right)$.

\section{Thiosulfate and $\mathrm{HBr}$ (Table 1 entry 4)}

\begin{tabular}{cccc}
\hline Reaction & $2 \mathrm{HBr}_{(\mathrm{aq})}+\mathrm{S}_{2} \mathrm{O}_{3}{ }^{2-}{ }_{(\mathrm{aq})}$ & $\rightarrow$ & $2 \mathrm{Br}^{-}{ }_{(\mathrm{aq})}+\mathrm{SO}_{2(\mathrm{aq})}+\mathrm{S}_{(\mathrm{s})}+\mathrm{H}_{2} \mathrm{O}_{(\mathrm{l})}$ \\
$\Delta H_{f}^{0}\left[\mathrm{kCal} \mathrm{mol}^{-1}\right]$ & $2 \times(-29.05)-155.9$ & & $2 \times(-29.05)-80+0-68.315$
\end{tabular}

$\Delta H_{r}^{0}=-206.4-(-214.0)=7.6 \mathrm{kCal}$ per reaction

Therefore, the reaction enthalpy is $31.8 \mathrm{~kJ}$ per mole of thiosulfate.

\section{Radical substitution (Manuscript Table 1 entry 2)}

The heat of the radical substitution was estimated using the energies of the bonds that are broken and formed during this reaction.

\begin{tabular}{|c|c|c|c|c|c|}
\hline Reaction & $\mathrm{Ar} \widehat{\sim}$ & $+\mathrm{Br}-\mathrm{Br}$ & $\rightarrow$ & $\mathrm{Ar}^{\prime}$ & $\mathrm{Br}-\mathrm{H}$ \\
\hline $\begin{array}{l}\text { Bond Energy }{ }^{(\mathrm{S} 3, \mathrm{~S} 4)} \\
{\left[\mathrm{kCal} \mathrm{mol}^{-1}\right]}\end{array}$ & 90 & 46 & & 63 & 88 \\
\hline
\end{tabular}

Therefore, the reaction enthalpy estimated to be $63 \mathrm{~kJ} \mathrm{~mol}^{-1}$. 


\subsection{Detailed Process Risk Assessment}

Estimated maximum volume of $\mathrm{Br}_{2}$ in the Photoreactor (first FM) at any point:

Under normal operation: reactor volume $=50 \mathrm{~mL}$, ratio input volumes to $\mathrm{Br}_{2}$ volume: $321 \mathrm{~mL}$ per $2389 \mathrm{~mL}$

$$
\frac{321 \times 50}{2389}=6.7 \mathrm{~mL}
$$

In the event of failure: should the substrate 1 pump (HNP, DCT) cease pumping, the $\mathrm{Br}_{2}$ volume in the first FM would increase to $10 \mathrm{~mL}$

\begin{tabular}{|c|c|c|c|c|}
\hline Possible risk/failure & Possible Observation & Consequence & Action & Preventative measure(s) \\
\hline $\begin{array}{l}\text { Pump } 1 \text { (Fuji, HBr) } \\
\text { failure }\end{array}$ & $\begin{array}{ll}\text { - } & \mathrm{No} \mathrm{Br}_{2} \text { formation } \\
\text { - } & \text { Mass flow meter } \\
& \text { shows low measured } \\
& \text { value } \\
\text { - } & \text { Pressure decrease }\end{array}$ & $\begin{array}{l}\text { - } \\
\text { - } \\
\text { Buildup of } \mathrm{NaBrO}_{3} \text { in } \\
\text { output } \\
\text { - } \mathrm{NaBrO}_{3} \text { and } \mathrm{Na}_{2} \mathrm{~S}_{2} \mathrm{O}_{3} \\
\text { mixed in collection flask } \\
\text { (minor exotherm expected) }\end{array}$ & $\begin{array}{l}\text { - } \mathrm{Switch} \mathrm{NaBrO}_{3} \text { and } \mathrm{Na}_{2} \mathrm{~S}_{2} \mathrm{O}_{3} \text { feeds } \\
\text { to water immediately. Dilute } \\
\text { collection/waste if necessary } \\
\text { - Then apply shutdown procedure }\end{array}$ & $\begin{array}{l}\text { - Thorough testing and monitoring of } \\
\text { pumps } \\
\text { - Add ice to the plastic bund around } \\
\text { the collection/waste flask to cool } \\
\text { mixture }\end{array}$ \\
\hline $\begin{array}{l}\text { Pump } 2(\mathrm{HNP}, \mathrm{DCT}) \\
\text { failure }\end{array}$ & $\begin{array}{ll}\text { - } & \text { Mass flow meter } \\
& \text { shows low measured } \\
& \text { value } \\
\text { - } & \text { Pressure decrease } \\
\text { - } & \mathrm{No} \mathrm{Br}_{2} \text { consumption } \\
\text { - } & \text { Output is not biphasic }\end{array}$ & 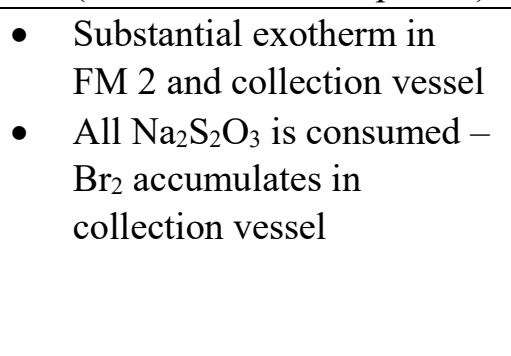 & $\begin{array}{l}\text { - Switch HBr pump to water. } \\
\text { - } \quad \text { Then apply shutdown procedure }\end{array}$ & $\begin{array}{l}\text { - Thorough testing and monitoring of } \\
\text { pumps } \\
\text { - Waste vessel temperature will be } \\
\text { monitored } \\
\text { - Add ice to the plastic bund around } \\
\text { the collection/waste flask to cool } \\
\text { mixture. }\end{array}$ \\
\hline $\begin{array}{l}\text { Pump } 3 \text { (HNP, } \\
\mathrm{NaBrO}_{3} \text { ) failure }\end{array}$ & $\begin{array}{ll}\text { - } & \mathrm{No} \mathrm{Br}_{2} \text { formation } \\
\text { - } & \text { Mass flow meter } \\
& \text { shows low measured } \\
& \text { value } \\
\text { - } & \text { Pressure decrease }\end{array}$ & $\begin{array}{ll} & \text { No reaction occurs. } \\
\text { - } & \mathrm{Na}_{2} \mathrm{~S}_{2} \mathrm{O}_{3} \text { will be acidified } \\
\text { (minor exotherm expected) }\end{array}$ & 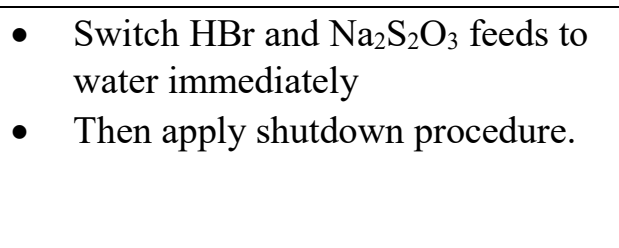 & $\begin{array}{l}\text { - Thorough testing and monitoring of } \\
\text { pumps } \\
\text { - Add ice to the plastic bund around } \\
\text { the collection/waste flask to cool } \\
\text { mixture }\end{array}$ \\
\hline
\end{tabular}




\begin{tabular}{|c|c|c|c|c|}
\hline $\begin{array}{l}\text { Pump } 4 \text { (HNP, } \\
\mathrm{Na}_{2} \mathrm{~S}_{2} \mathrm{O}_{3} \text { ) failure }\end{array}$ & $\begin{array}{ll}\text { - } & \text { Mass flow meter } \\
\text { shows low measured } \\
\text { value } \\
\text { - } \\
\text { - } \\
\mathrm{Br}_{2} \text { is nos nure decrease } \\
\end{array}$ & $\begin{array}{ll}-\mathrm{Br}_{2} \text { remains in output } \\
\text { solution (accumulates in } \\
\text { organic phase) - can be a } \\
\text { significant hazard. }\end{array}$ & $\begin{array}{ll}\text { - } & \text { Switch } \mathrm{NaBrO}_{3} \text { and } \mathrm{HBr} \text { feed to } \\
\text { water immediately } \\
\text { - } & \text { Apply shutdown procedure }\end{array}$ & $\begin{array}{l}\text { - Thorough testing and monitoring of } \\
\text { pumps } \\
\text { - Add ice to the plastic bund around } \\
\text { the collection/waste flask to cool } \\
\text { mixture } \\
\text { - Add } \mathrm{Na}_{2} \mathrm{~S}_{2} \mathrm{O}_{3} \text { solution to waste vessel } \\
\text { and mix phases well between } \\
\text { experimental runs, using an overhead } \\
\text { stirrer }\end{array}$ \\
\hline LED failure & $\begin{array}{l}\text { - } \\
\text { - } \\
\text { Reduced temperature } \\
\text { difference between } \\
\text { thermostat bath and } \\
\text { thermal fluid channel } \\
\text { - } \mathrm{Br}_{2} \text { is not quenched }\end{array}$ & $\begin{array}{ll}\mathrm{Br}_{2} \text { remains in output } \\
\text { solution (accumulates in } \\
\text { organic phase) - can be a } \\
\text { significant hazard. }\end{array}$ & $\begin{array}{l}\text { - } \quad \text { Switch } \mathrm{NaBrO}_{3} \text { and } \mathrm{HBr} \text { feed to } \\
\text { water immediately } \\
\text { - } \quad \text { Then apply shutdown procedure }\end{array}$ & $\begin{array}{l}\text { - Add ice to the plastic bund around } \\
\text { the collection/waste flask to cool } \\
\text { mixture } \\
\text { - } \mathrm{Add}_{2} \mathrm{Na}_{2} \mathrm{O}_{3} \text { solution to waste vessel } \\
\text { and mix phases well between } \\
\text { experimental runs, using an overhead } \\
\text { stirrer }\end{array}$ \\
\hline $\begin{array}{l}\text { Use of intense visible } \\
\text { light }(405 \mathrm{~nm})\end{array}$ & Normal operation & - $\quad$ Potential eye damage & $\begin{array}{l}\text { In the event of exposure, apply } \\
\text { shutdown procedure }\end{array}$ & $\begin{array}{l}\text { - Keep tinted reactor case shut at all } \\
\text { times when operating LEDs } \\
\text { Everyone in the room during } \\
\text { operation must wear tinted goggles } \\
\text { - Access to room is restricted to } \\
\text { authorized users and "do not enter" } \\
\text { sign is displayed on door }\end{array}$ \\
\hline $\begin{array}{l}\text { LED thermostat or } \\
\text { booster pump failure }\end{array}$ & $\begin{array}{ll} & \text { Increase in LED } \\
\text { temperature (heat } \\
\text { exchange channel) }\end{array}$ & $\begin{array}{l}\text { LEDs will overheat and } \\
\text { break, leading to no } \mathrm{Br}_{2} \\
\text { consumption in the reactor. }\end{array}$ & 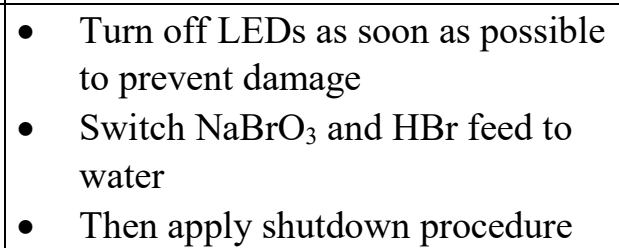 & $\begin{array}{l}\text { - Thorough testing and monitoring of } \\
\text { LED thermostat }\end{array}$ \\
\hline
\end{tabular}




\begin{tabular}{|c|c|c|c|c|}
\hline $\begin{array}{l}\text { Reaction thermostat } \\
\text { failure/incapable of } \\
\text { dealing with exotherm }\end{array}$ & $\begin{array}{l}\text { - Increase in reaction } \\
\text { channel temperature }\end{array}$ & $\begin{array}{l}\text { Exotherm, potential } \\
\text { vaporization of } \mathrm{Br}_{2}\end{array}$ & - Apply shutdown procedure & $\begin{array}{l}\text { - Thorough testing and monitoring of } \\
\text { thermostat and booster pump }\end{array}$ \\
\hline $\begin{array}{l}\text { Corrosion/failure of } \\
\text { reaction channel } \\
\text { tube/connector }\end{array}$ & $\begin{array}{l}\text { - Leakage of } \\
\text { acidic/corrosive } \\
\text { fluid }\end{array}$ & $\begin{array}{l}\text { - } \begin{array}{l}\text { Potential injury and } \\
\text { damage of equipment }\end{array}\end{array}$ & - Apply shutdown procedure & $\begin{array}{l}\text { - Leak/pressure test reaction setup at } \\
10 \text { bar prior to use } \\
\text { - } \quad \text { Keep reactor case closed during } \\
\text { operation and fumehood sashes } \\
\text { closed wherever possible }\end{array}$ \\
\hline $\begin{array}{l}\text { Buildup of gas in } \\
\text { collection/waste } \\
\text { containers - reaction } \\
\text { of } \mathrm{Na}_{2} \mathrm{~S}_{2} \mathrm{O}_{3} \text { with acid } \\
\text { over time may form } \\
\mathrm{SO}_{2} \text { gas }\end{array}$ & $\begin{array}{l}\text { - Waste vessels may } \\
\text { begin to bulge after } \\
\text { some time }\end{array}$ & 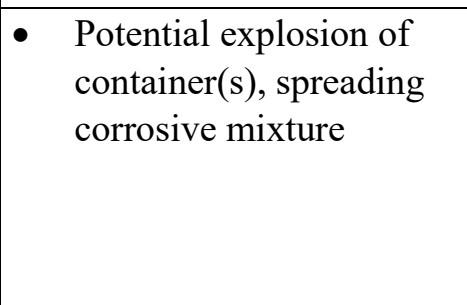 & $\begin{array}{l}\text { - } \quad \text { Keep collection vessels cooled } \\
\text { with ice during operation } \\
\text { - Clean spill as soon as possible } \\
\text { (spill kit in the lab) }\end{array}$ & $\begin{array}{l}\text { Ensure that containers are not sealed } \\
\text { fully and are left to stand for at least } \\
\text { a week prior to closing for further } \\
\text { disposal. } \\
\text { - Mix phases well between experiment } \\
\text { runs, using an overhead stirrer. }\end{array}$ \\
\hline $\begin{array}{l}\text { Blockage of process } \\
\text { stream tubing/FM }\end{array}$ & $\begin{array}{l}\text { - } \begin{array}{l}\text { Dramatic increase in } \\
\text { pressure }\end{array}\end{array}$ & $\begin{array}{l}\text { - } \begin{array}{l}\text { Potential for fittings to } \\
\text { burst, reactor to shatter }\end{array}\end{array}$ & $\begin{array}{l}\text { - } \quad \text { Turn off pumps, then LEDs. } \\
\text { Allow pressure to return to } \\
\text { ambient, then attempt to unblock } \\
\text { tubing }\end{array}$ & 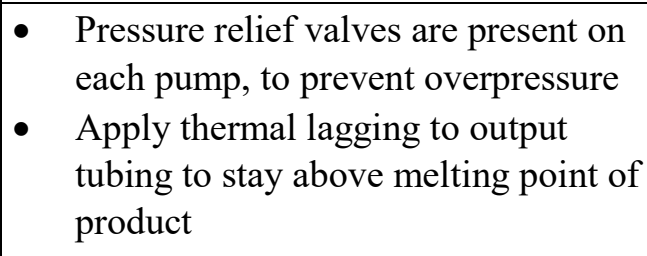 \\
\hline FM breaks/shatters & $\begin{array}{ll}\text { - } & \text { Noise/visible signs } \\
\text { - } & \text { Sudden drop of } \\
& \text { pressure } \\
\text { - } & \text { Leakage of reaction } \\
& \text { mixture. } \\
\end{array}$ & $\begin{array}{l}\text { - } \quad \begin{array}{l}\text { Potential injury and } \\
\text { damage of equipment. }\end{array}\end{array}$ & - Apply shutdown procedure & $\begin{array}{l}\text { - Leak/pressure test all parts at } 10 \text { bar } \\
\text { prior to use }\end{array}$ \\
\hline $\begin{array}{l}\text { Backflow into feed } \\
\text { vessels due to pump } \\
\text { failure }\end{array}$ & $\begin{array}{ll}-\quad & \text { Mass flow meter } \\
& \text { shows low or } \\
\text { negative } \\
\text { measurement } \\
\text { - } & \text { Pressure decrease } \\
\end{array}$ & 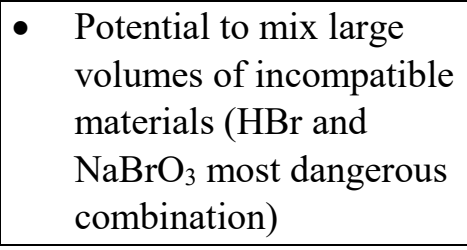 & $\begin{array}{l}\text { - Switch all feeds to wash solvent } \\
\text { (backflow will then be redirected to } \\
\text { water/isopropanol feeds). } \\
\text { - Then apply shutdown procedure }\end{array}$ & $\begin{array}{l}\text { - } \quad \text { Thoroughly test pumps prior to use } \\
\text { - } \\
\text { closely }\end{array}$ \\
\hline
\end{tabular}




\begin{tabular}{|c|c|c|c|c|}
\hline Power cut & \begin{tabular}{ll|}
- & Loss of power \\
(including fumehood \\
extraction)
\end{tabular} & $\begin{array}{l}\text { - Pumps, thermostats and } \\
\text { LEDs turn off, resulting in } \\
\mathrm{Br}_{2} \text { buildup in reactor } \\
\text { - Potential exotherm and } \mathrm{Br}_{2} \\
\text { vaporization }\end{array}$ & 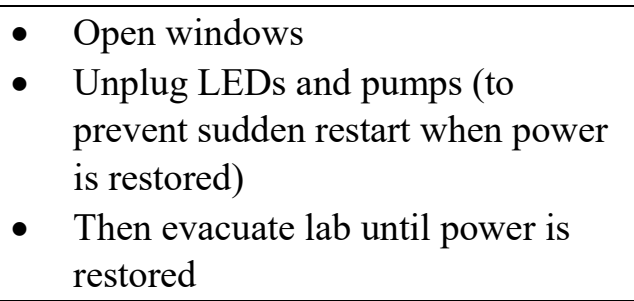 & - No additional measures possible \\
\hline $\begin{array}{l}\text { Internal breakage of } \\
\text { glass (reaction channel } \\
\text { into heat exchange } \\
\text { channel) }\end{array}$ & $\begin{array}{ll}\text { - } & \text { Noise/visible signs } \\
\text { - } & \text { Sudden drop of } \\
\text { pressure } \\
\text { - } & \text { Anticipated smell of } \\
\text { heated } \\
\text { substrate/product } \\
\text { mixture }\end{array}$ & $\begin{array}{l}\text { All relevant streams (e.g. } \\
\mathrm{Br}_{2} \text { and product) will leak } \\
\text { into the heat exchange } \\
\text { channel (heat exchange } \\
\text { medium is water) } \\
\text { Large exotherm, corrosion } \\
\text { of thermostat and loss of } \\
\text { containment }\end{array}$ & $\begin{array}{l}\text { Switch pumps to water and switch } \\
\text { off thermostat } \\
\text { - } \\
\text { Open lab windows } \\
\text { Apply shutdown procedure (if } \\
\text { sufficient time) } \\
\text { Evacuate lab until the exotherm has } \\
\text { settled }\end{array}$ & $\begin{array}{l}\text { - Pressure testing of both process and } \\
\text { heat exchange channel } \\
\text { - Careful monitoring of pressure }\end{array}$ \\
\hline
\end{tabular}




\section{Setup}

\subsection{PID with part list}

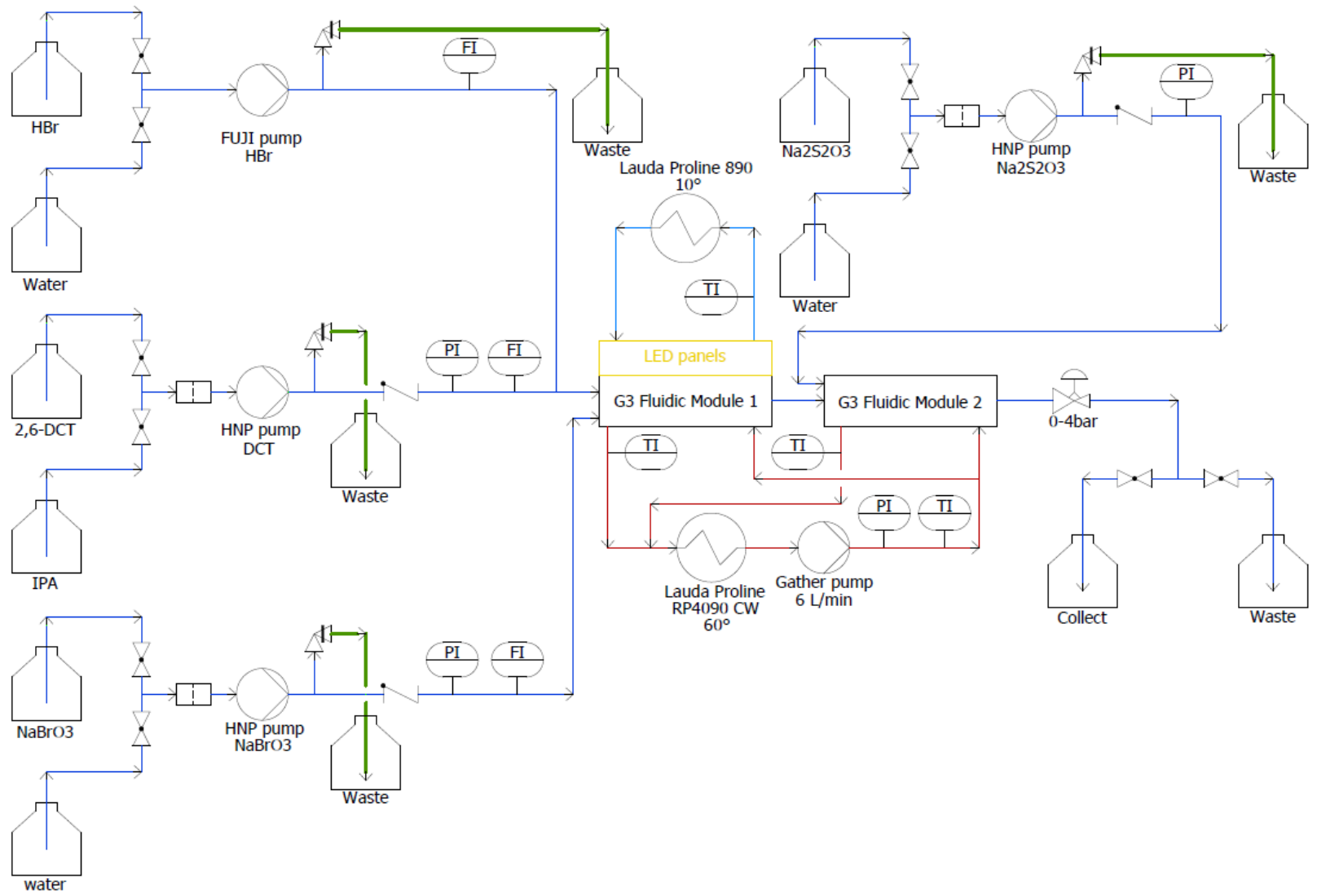

Figure S11. Piping and instrumentation diagram (PID) showing the process streams in black, heat exchange channels for the reaction and quench FMs in red, and the LED cooling cycle in blue. PI = pressure sensor; $\mathrm{FI}=$ flow meter; $\mathrm{TI}=$ temperature sensor.

The reactions were conducted in a commercial continuous-flow reactor: Corning ${ }^{\circledR}$ AdvancedFlow ${ }^{\mathrm{TM}} \mathrm{G} 3$ Photo Reactor. The reactor used in this work consisted of two fluidic modules $(310 \times$ $250 \mathrm{~mm}, 1.5 \mathrm{~mm}$ channel depth, $50 \mathrm{~mL}$ internal volume per FM), encased within a high capacity heat exchange channel. An LED panel, equipped with an array of $405 \mathrm{~nm}$ LEDs $(192 \times 2.17 \mathrm{~W}$ LEDs per panel, 384 LEDs in total), was mounted on both sides of the first fluidic module. A Lauda Proline RP 890 thermostat (1.1 kW cooling power, ethanol as heat exchange fluid) set to 10 ${ }^{\circ} \mathrm{C}$ was used to cool the LEDs. A temperature sensor was place in the heat exchange channel at the outlet of the LED panels. For controlling the temperature in the fluidic modules, a Lauda Proline 
RP $4090 \mathrm{CW}$ thermostat (4.0 kW cooling power, water as heat exchange fluid) was used in combination with a Gather gear pump (2M-J/24/) as booster pump to increase the flowrate to $6 \mathrm{~L}$ $\min ^{-1}$. A pressure sensor and three temperature sensors were added to the heat exchange channels as indicated in Figure S11 and Figure S15.

Pumps: sodium thiosulfate: HNP mzr-7208-hs-f S +SW, 2,6-dichlorotoluene: HNP mzr-7255hs-f S +W sodium bromate: HNP mzr-7255-cs-f S, HBr: Fuji Super Metering Pump HYM P0B2-NS-PL-08

Inline filters: sodium bromate and 2,6-dichlorotoluene: HNP F-MI3-T, sodium thiosulfate: Swagelok filter 40 micron.

Pressure relief valves HBr: Fuji Safety Valve AZ02505, others: Swagelok proportional relief valves. All relief valves were set to 10 bar. 


\subsection{Photos of the Setup}

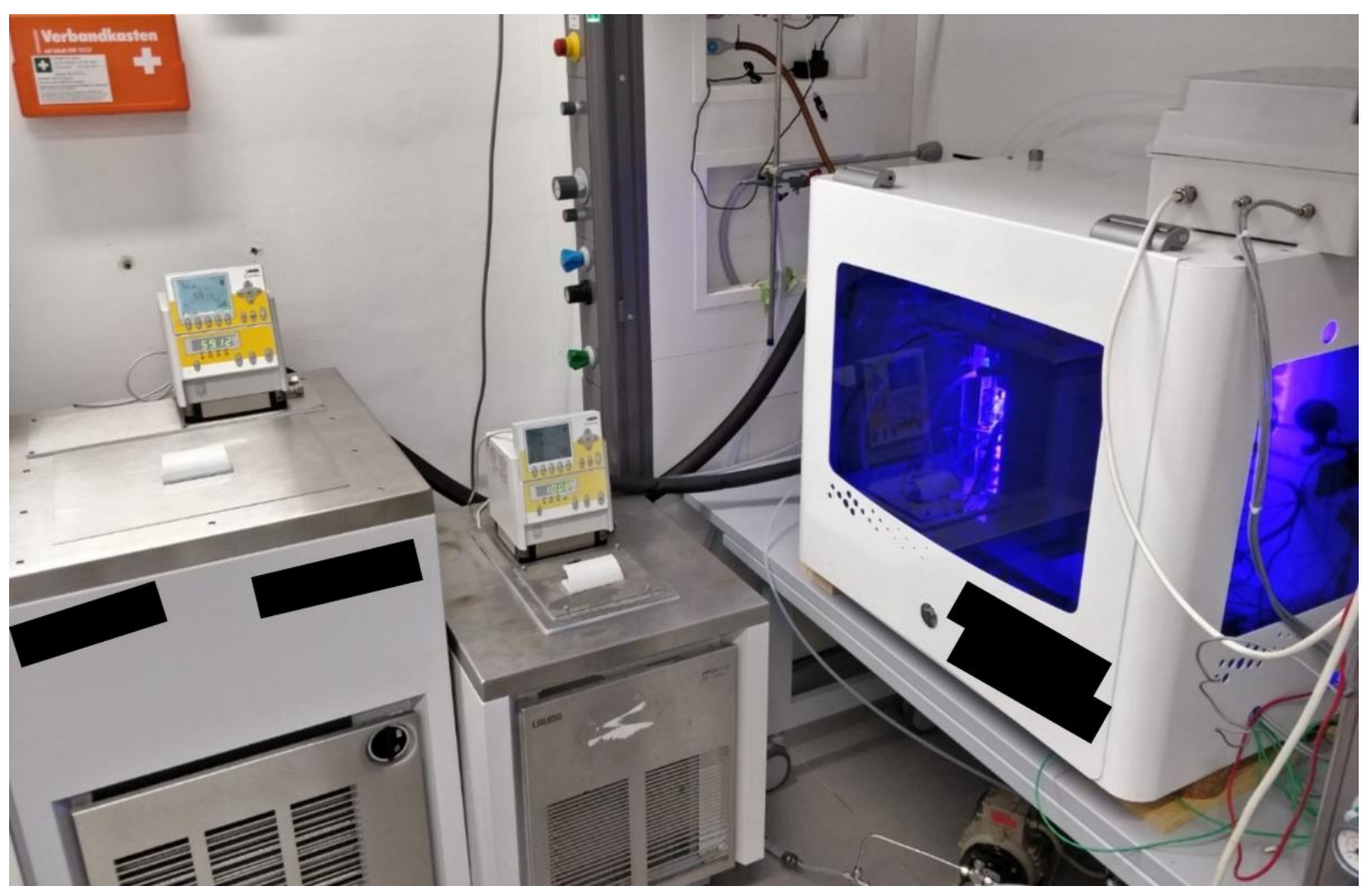

Figure S12. Left fumehood containing the closed reactor housing with the LEDs turned on. Outside the fumehood are the two thermostats: the Lauda Proline RP 4090 (connected via the booster pump, located under the reactor) and the Lauda Proline RP 890. 


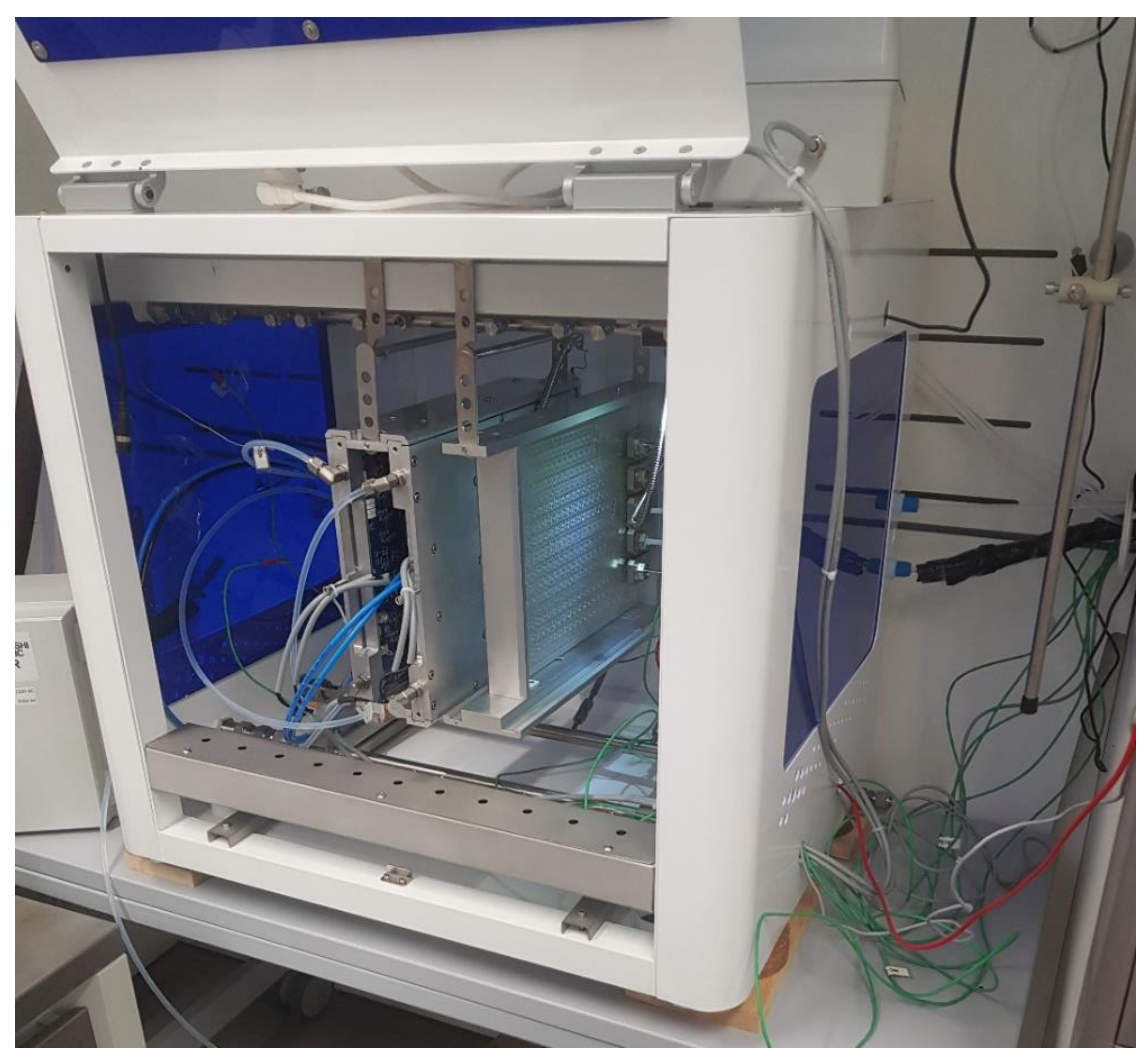

Figure S13. Left fumehood, showing the opened reactor housing.

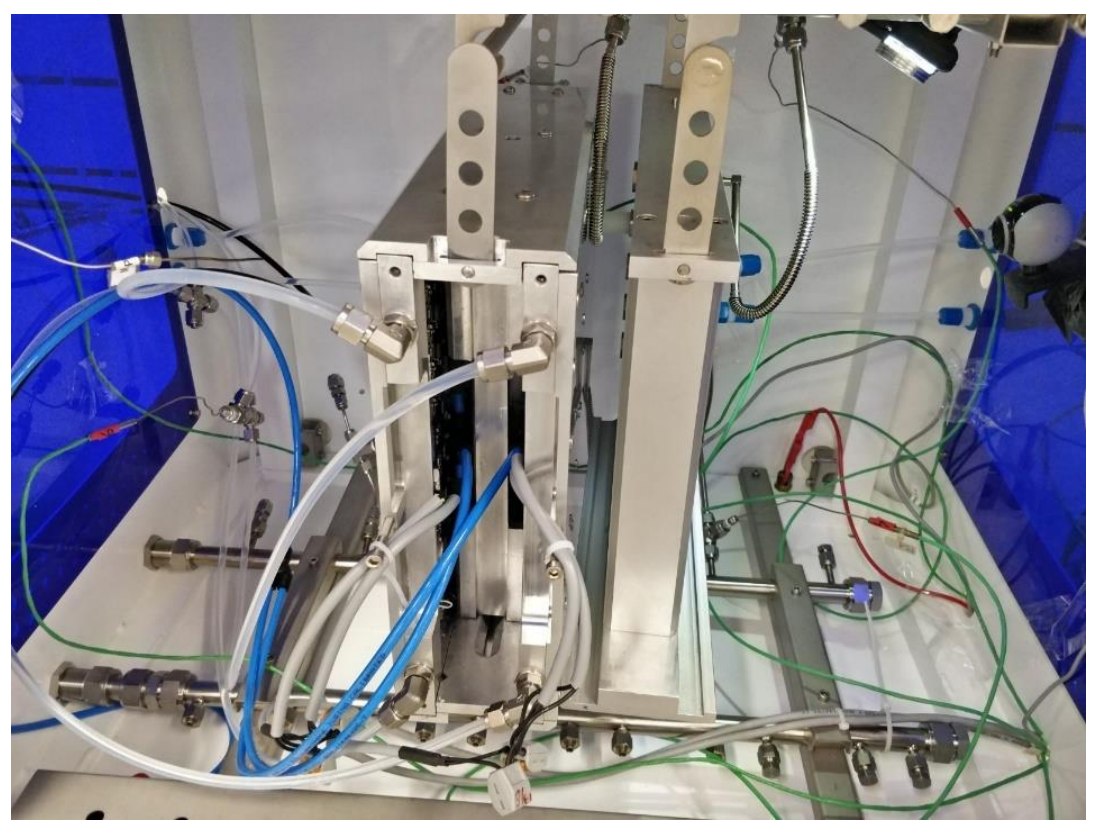

Figure S14. Inside of the reactor housing. 

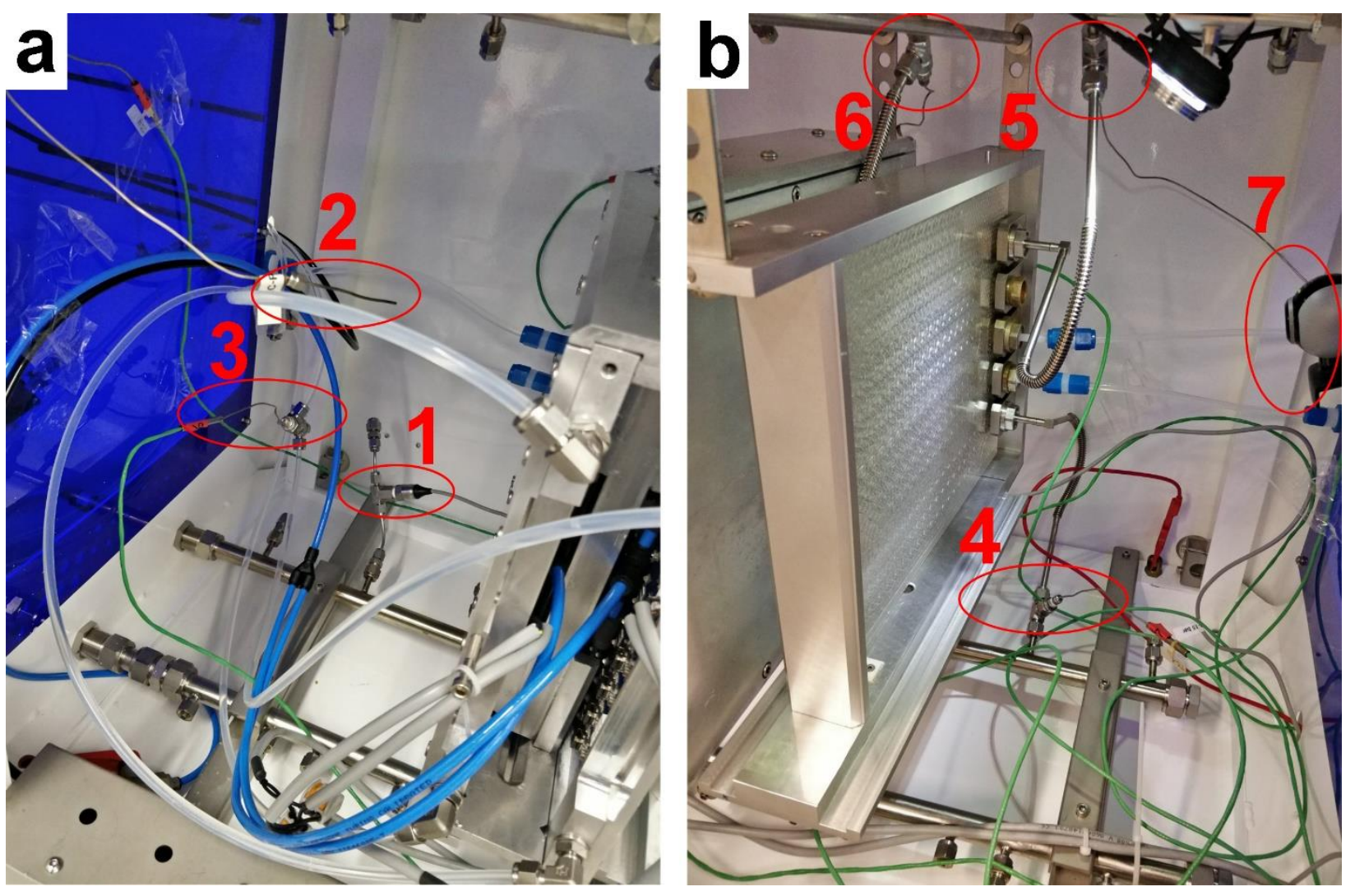

Figure S15. Inside of the reactor a) left side of reactor FMs, b) right side of FMs. 1: pressure sensor in the heat exchange channel before the fluidic modules. 2: Temperature sensor measuring the ambient $\mathrm{T}$ inside the reactor box. 3: Temperature sensor measuring the cooling liquid for the LEDs, after passing through the two LED arrays. 4: Temperature sensor measuring the heat exchange channel before passing through the fluidic modules. 5: Temperature sensor measuring the heat exchange channel after passing through the second (quench) FM. 6: Temperature sensor measuring the heat exchange channel after passing through the first FM. 7: Webcam allowing visual monitoring of the reaction mixture inside the quench FM. 


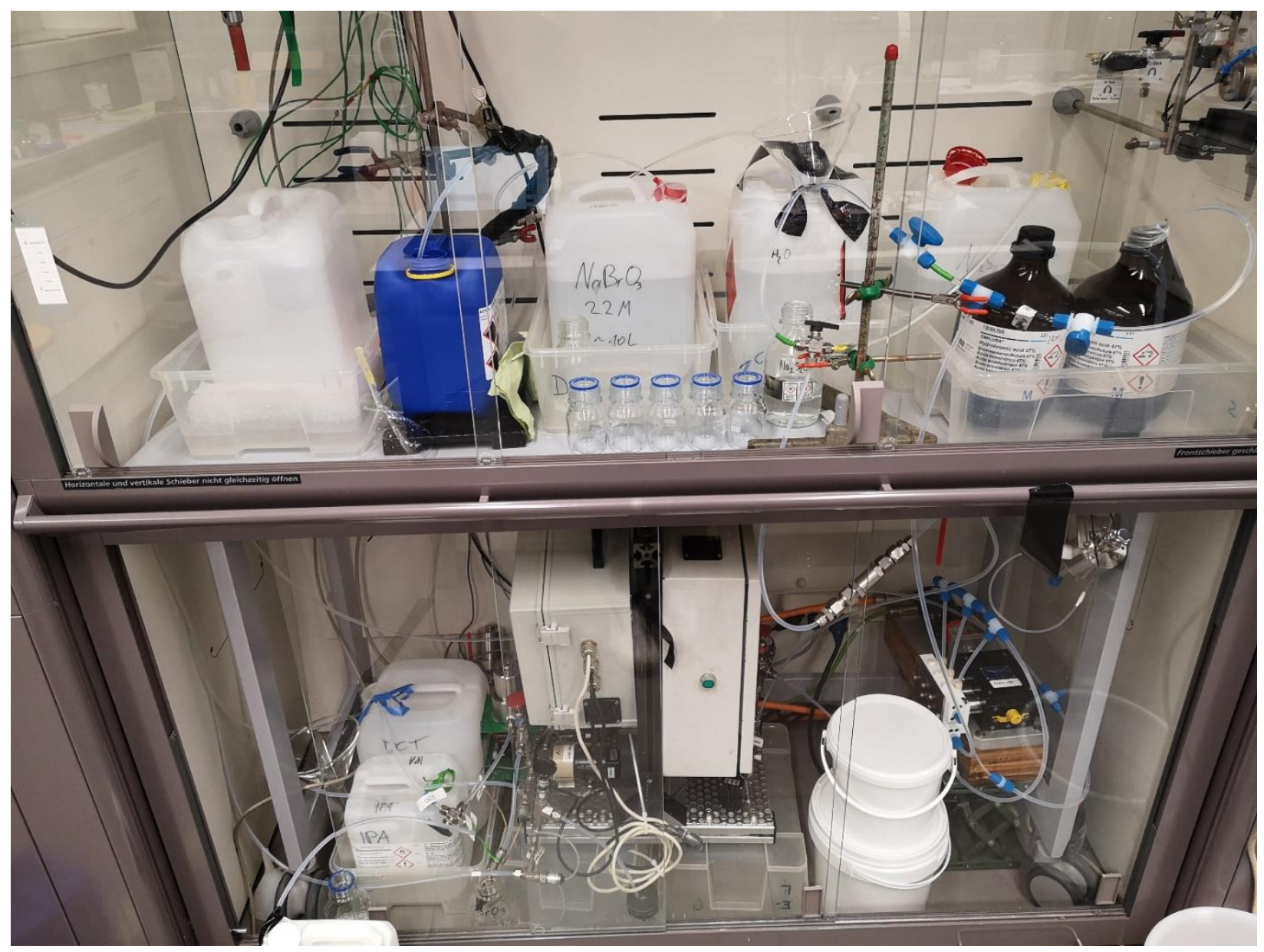

Figure S16. Right fumehood containing pumps and their periphery, containers for the reaction and washing liquids and for collection as well as the hardware necessary for controlling the pumps, as well as pressure and temperature sensors. Photo was taken prior to installation of mass flow meters. 


\subsection{Webcam Photos}

Table S7. Details on the conditions of the snapshots shown in Figure S17.

\begin{tabular}{|c|c|c|c|}
\hline $\begin{array}{c}\text { Photograph in } \\
\text { Figure S17 }\end{array}$ & $\begin{array}{c}\text { Entry in } \\
\text { Manuscript Table } 2\end{array}$ & Conversion [\%] & $\begin{array}{l}\text { Flow rate } \mathrm{NaS}_{2} \mathrm{O}_{3} \\
{\left[\mathrm{~mL} \mathrm{~min}^{-1}\right]}\end{array}$ \\
\hline $\mathrm{a}$ & 1 & 10 & 85 \\
\hline $\mathrm{b}$ & 2 & 31 & 85 \\
\hline $\mathrm{c}$ & 5 & 81 & 85 \\
\hline $\mathrm{d}$ & 3 & 76 & 70 \\
\hline e & 11 & 77 & 70 \\
\hline $\mathrm{f}$ & 4 & 77 & 62 \\
\hline g & 13 & 84 & 50 \\
\hline $\mathrm{h}$ & 9 & 88 & 58 \\
\hline
\end{tabular}




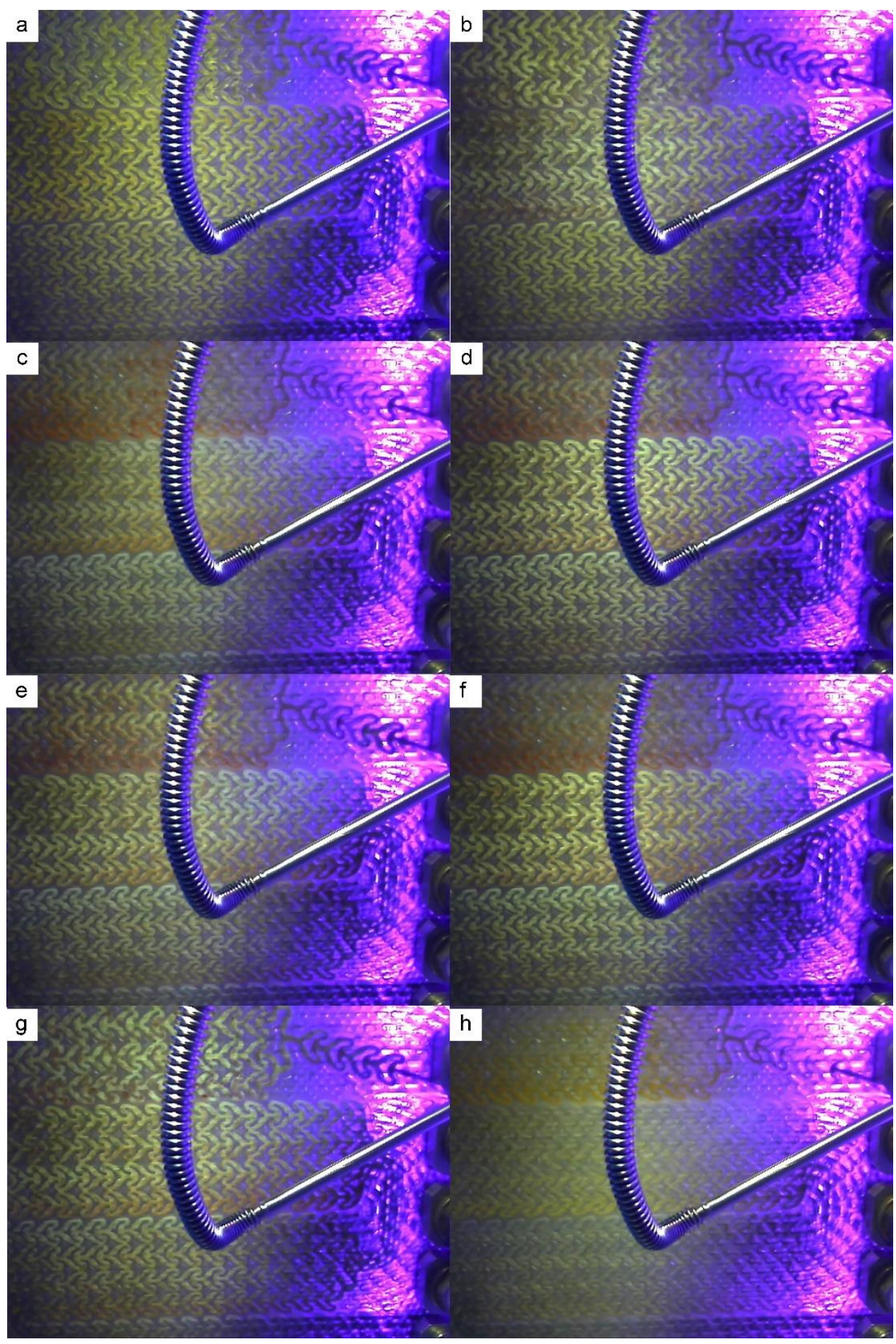

Figure S17: Images are snapshots from the video captured by the webcam, showing the quench FM. The purple light on the right originates from the reactor LEDs. Details are given in Table S7. 


\section{Experimental Results}

\subsection{Additional Process Data}

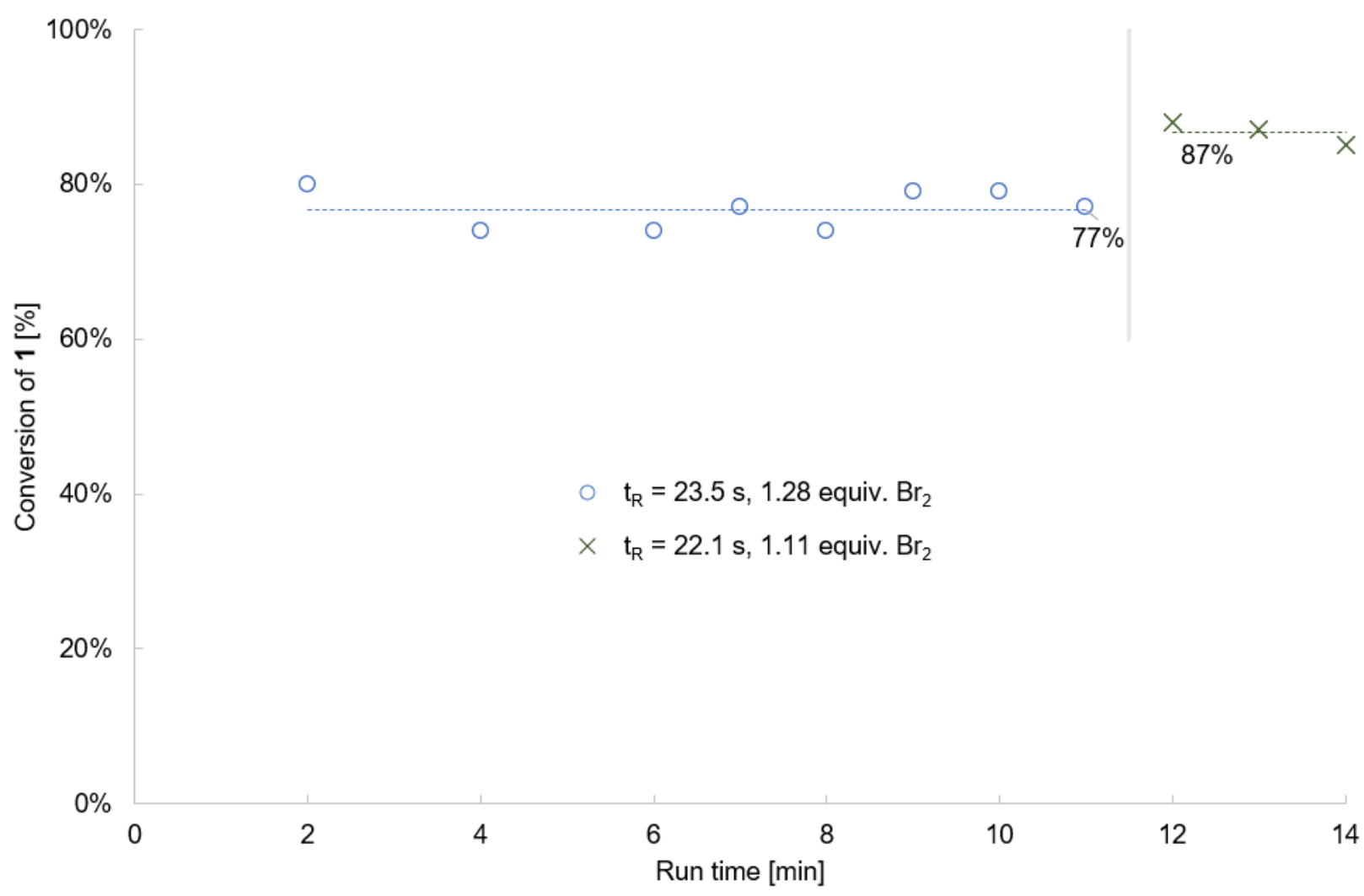

Figure S18. Stability test run over 14 minutes. After about 8 minutes the flowrates were adjusted to match the best conditions found previously ( 22 seconds and 1.1 equivalents $\mathrm{Br}_{2}$ ). The dotted lines mark the average conversion over the two sets of conditions. 


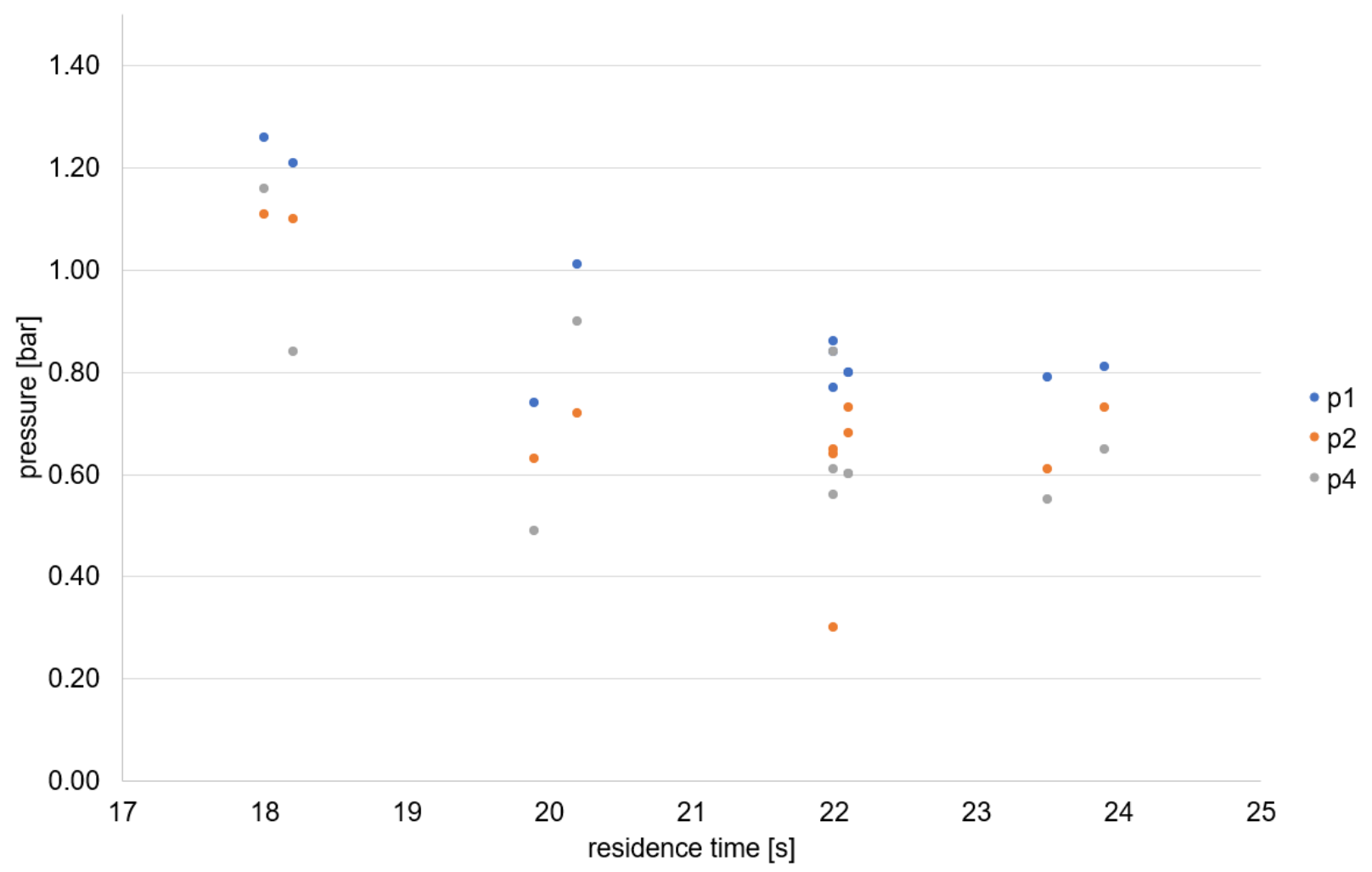

Figure S19. Observed pressure drop values in the reactor. Observed pressures after the DCT pump (p1), the bromate pump (p2) and the thiosulfate pump (p4), plotted against the residence time in the reaction FM. 


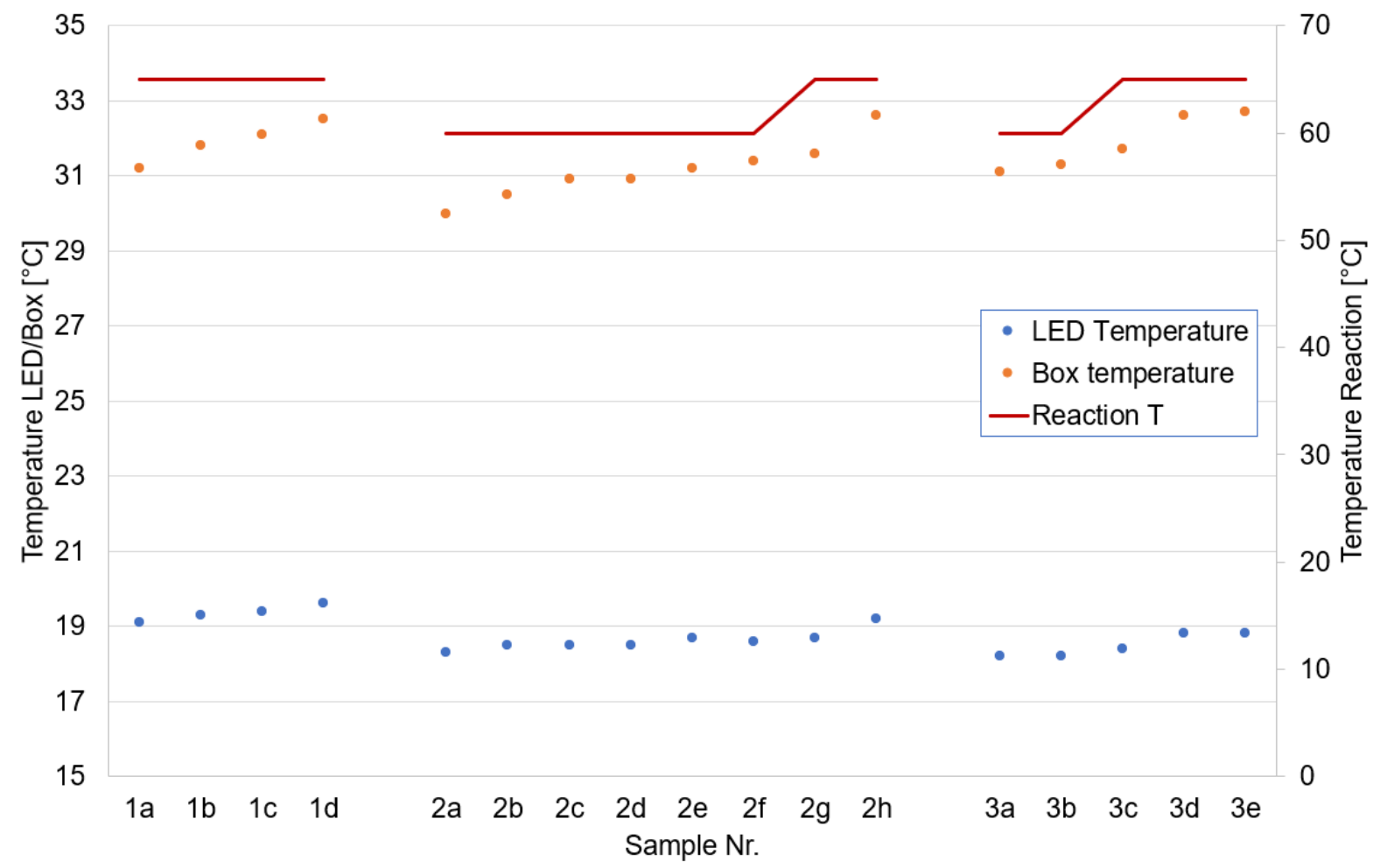

Figure S20. Trend of the thermal fluid temperatures after passing through the LED panels (blue dots, equilibrating around $19^{\circ} \mathrm{C}$ ) and the air temperature inside the reactor housing (orange dots, equilibrating around $30-33{ }^{\circ} \mathrm{C}$ ), over the course of three optimization runs. Since these temperatures are also influenced by the reaction temperature, the red line indicates the corresponding temperature set point in the reactor thermostat. The timeframes of these runs are $\sim 12 \min (1 \mathrm{a}-1 \mathrm{~d}), \sim 32 \mathrm{~min}(2 \mathrm{a}-2 \mathrm{~h})$ and $\sim 19 \mathrm{~min}(3 \mathrm{a}-3 \mathrm{e})$. 


\subsection{Reactor Fouling}

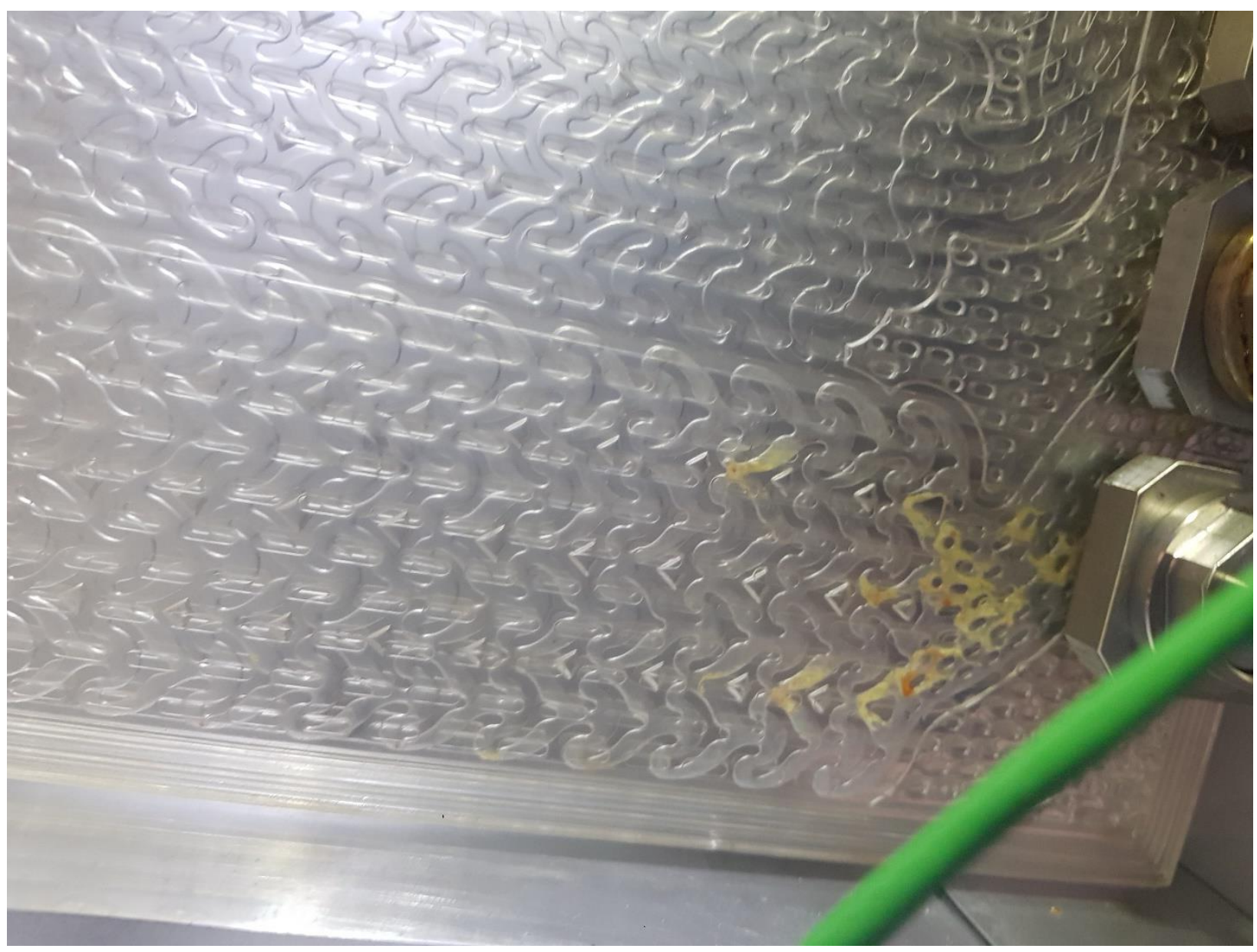

Figure S21. Quench FM, fouling by sulfur. The fouling was only observed during runs with low conversion, since the sulfur is formed from thiosulfate under acidic conditions (excess $\mathrm{HBr}$ ). 


\subsection{NMRs}

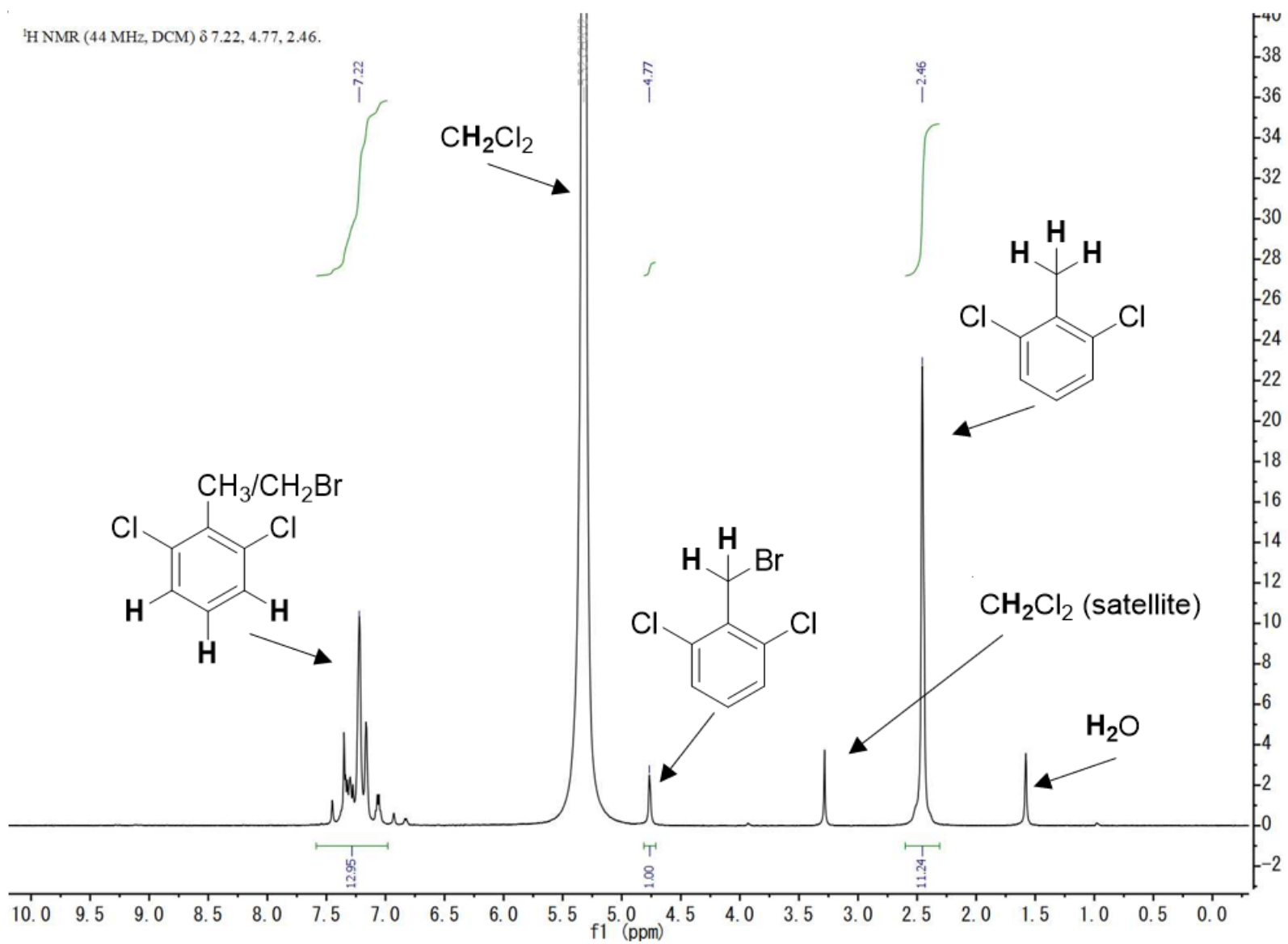

Figure S22. ${ }^{1} \mathrm{H}$ NMR corresponding to Manuscript Table 2 entry 1. 


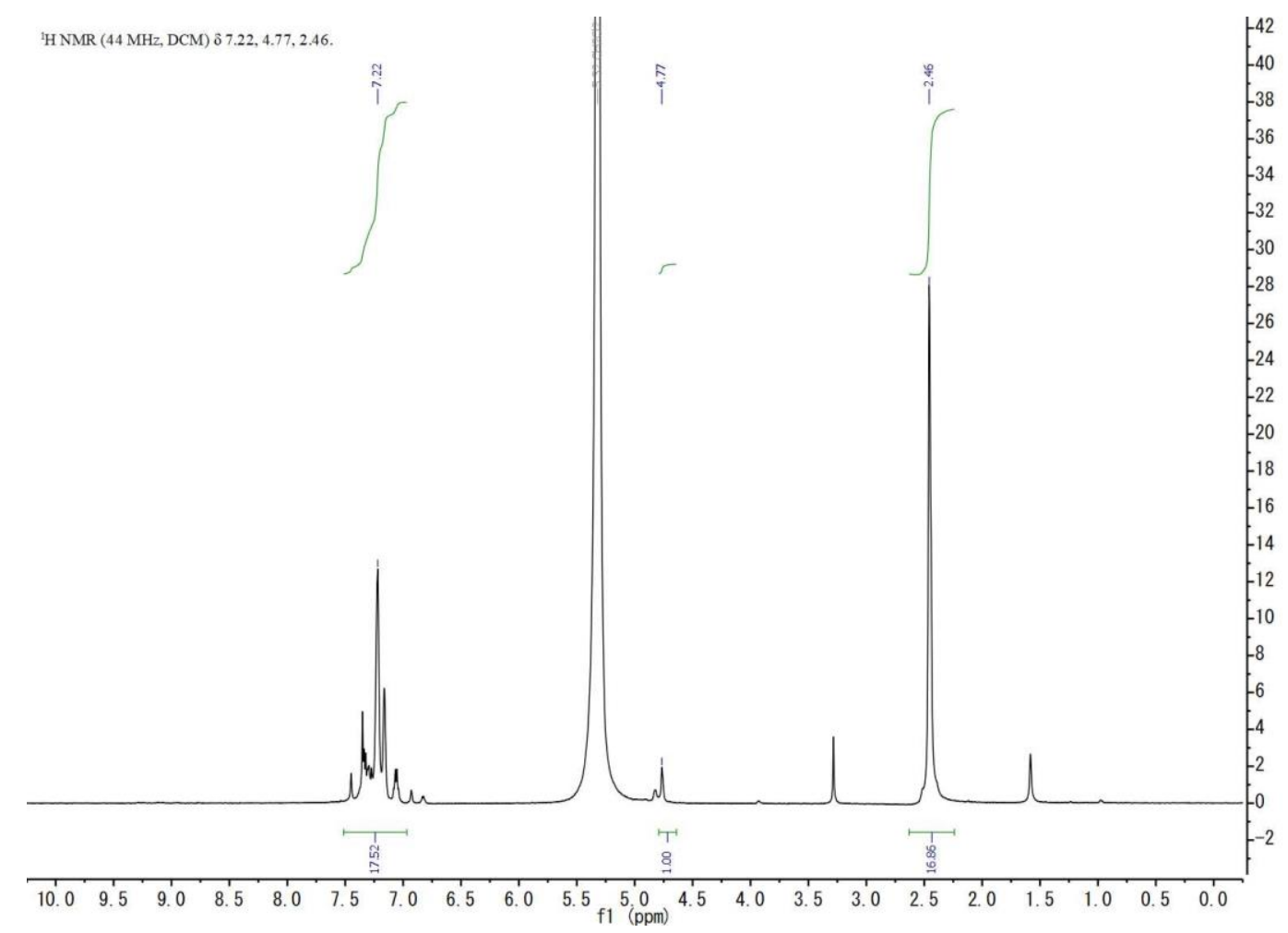

Figure S23. ${ }^{1} \mathrm{H}$ NMR corresponding to Manuscript Table 2 entry 1 (duplicate).

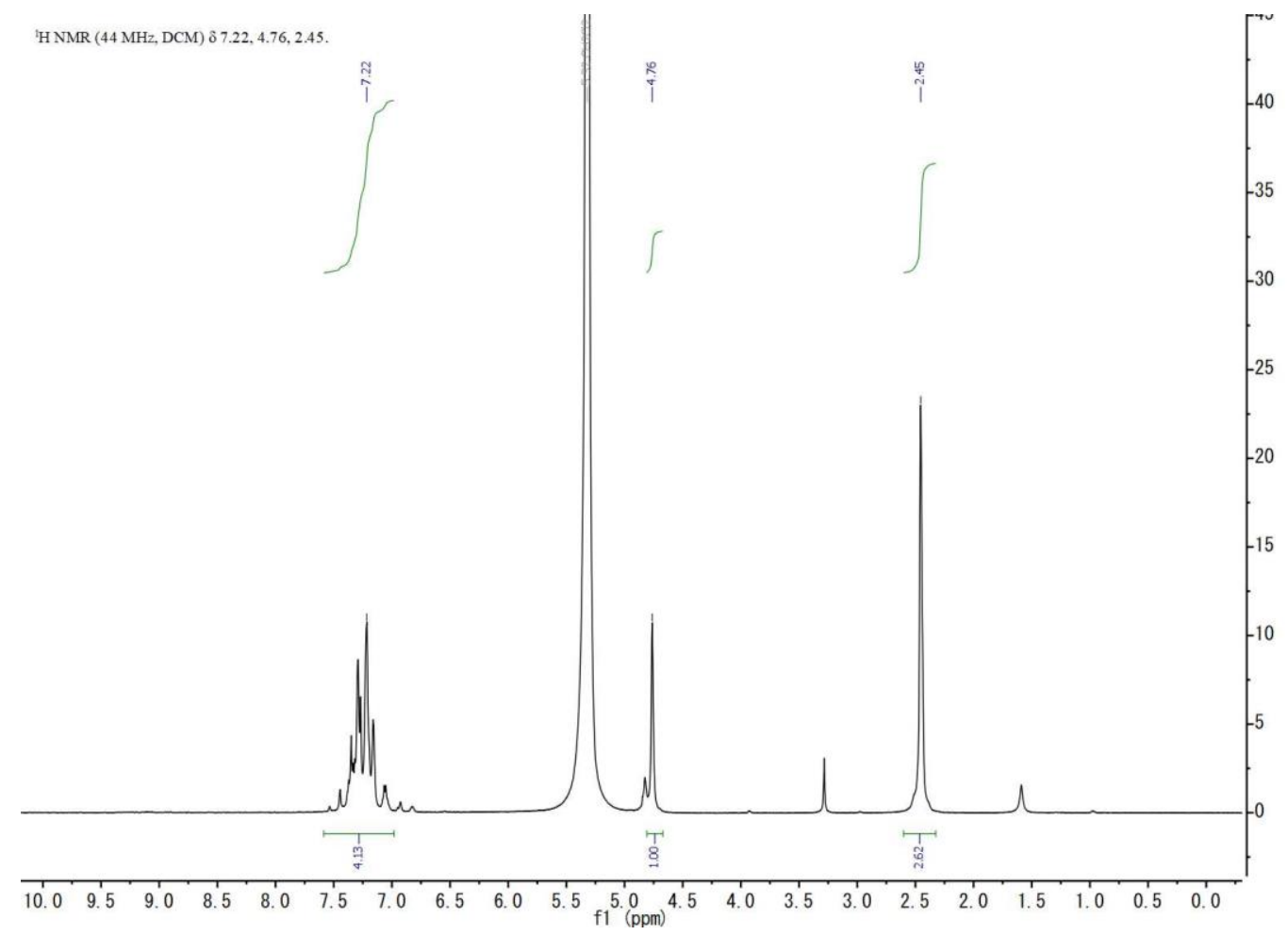

Figure S24. ${ }^{1} \mathrm{H}$ NMR corresponding to Manuscript Table 2 entry 2. 


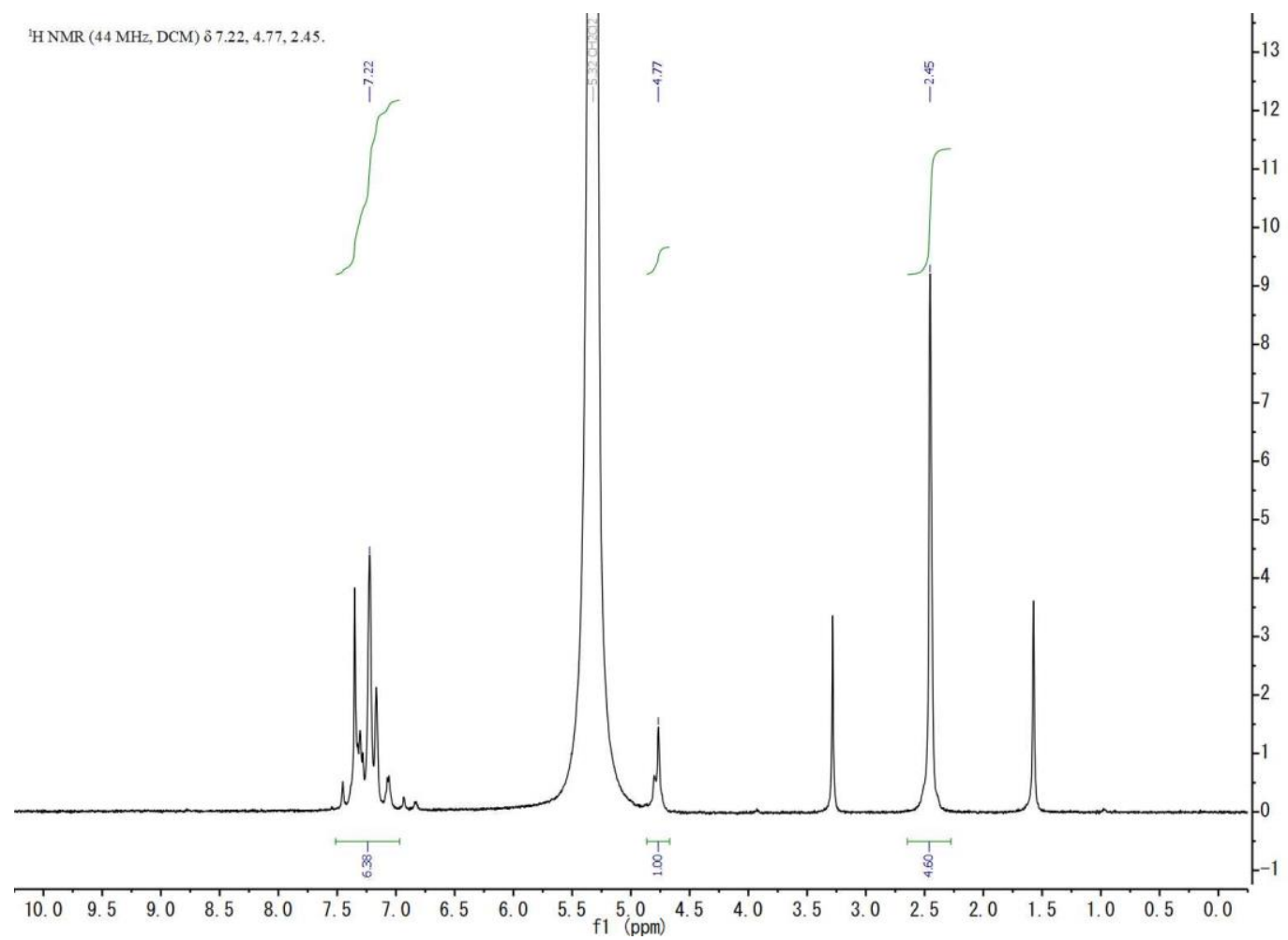

Figure S25. ${ }^{1} \mathrm{H}$ NMR corresponding to Manuscript Table 2 entry 2 (duplicate).

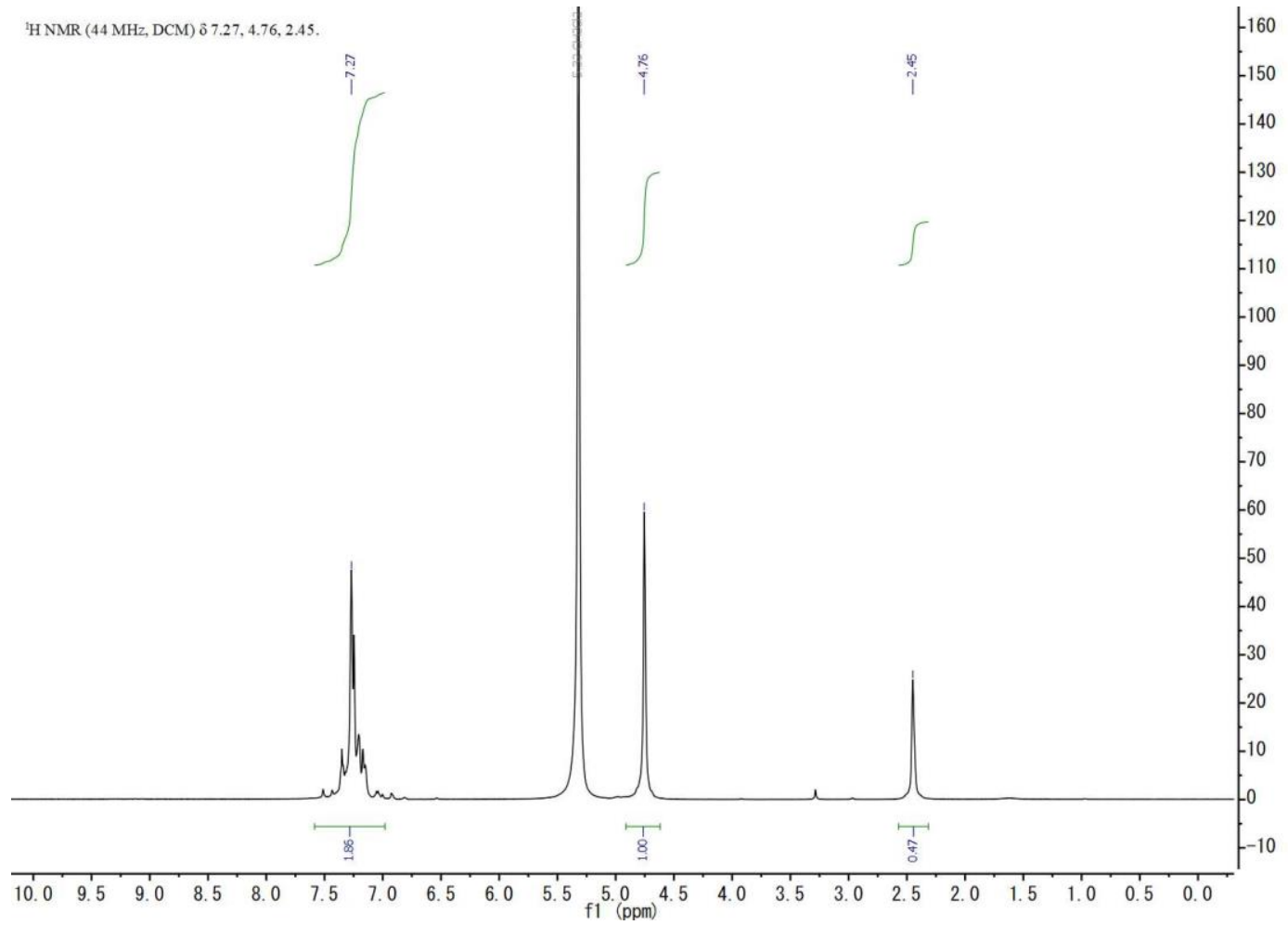

Figure S26. ${ }^{1} \mathrm{H}$ NMR corresponding to Manuscript Table 2 entry 3. 


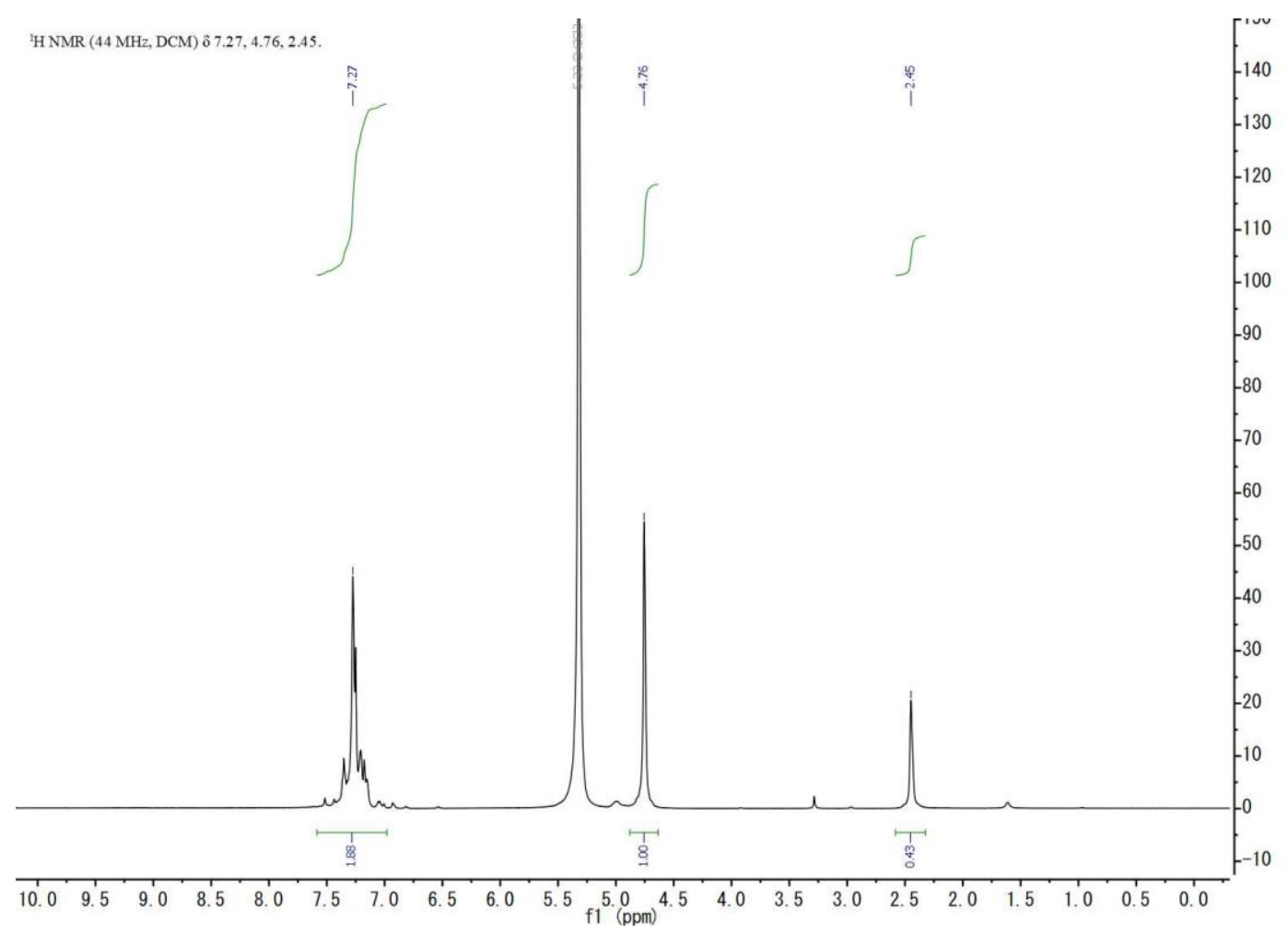

Figure S27. ${ }^{1} \mathrm{H}$ NMR corresponding to Manuscript Table 2 entry 4.

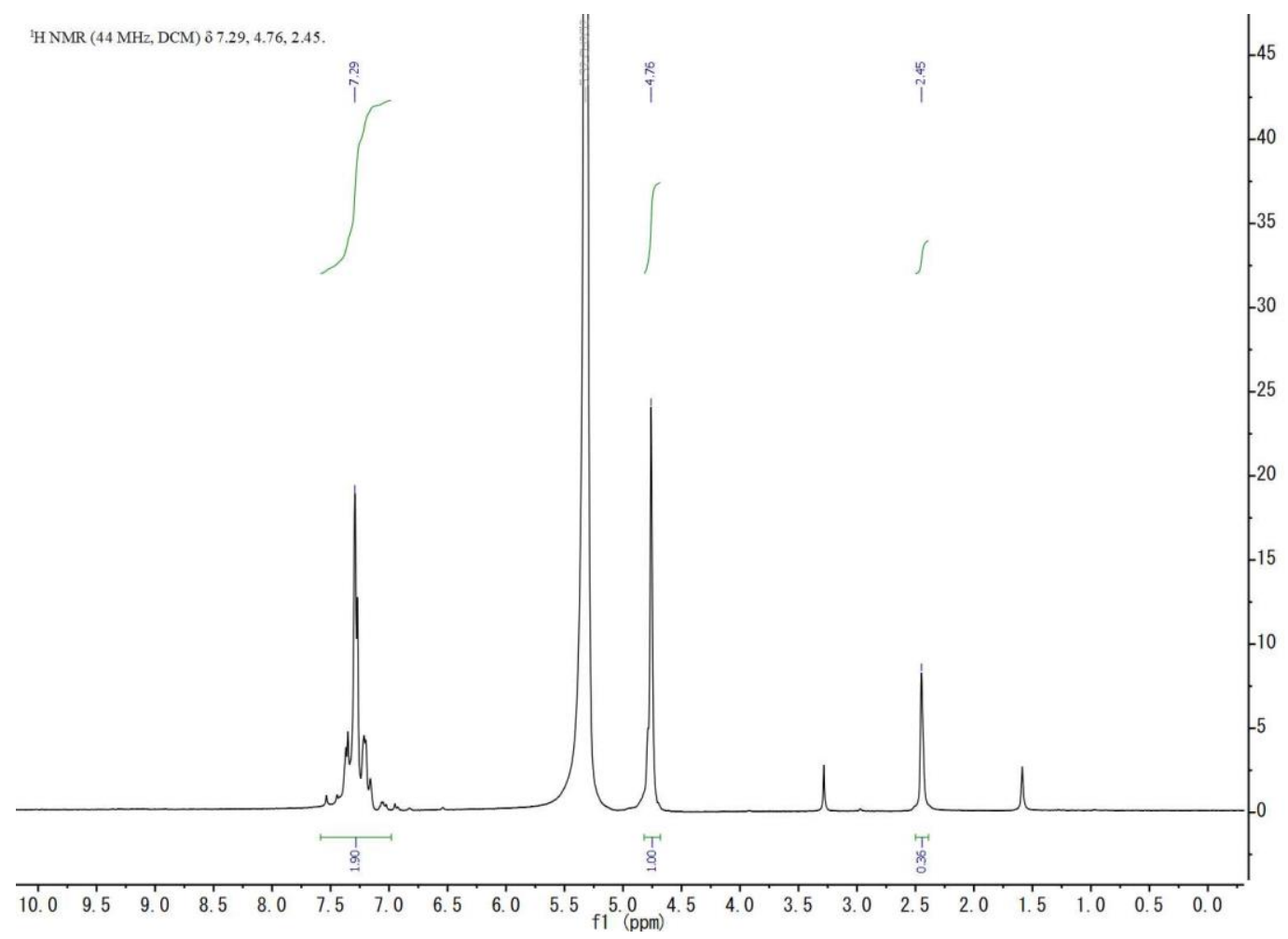

Figure S28. ${ }^{1} \mathrm{H}$ NMR corresponding to Manuscript Table 2 entry 5. 


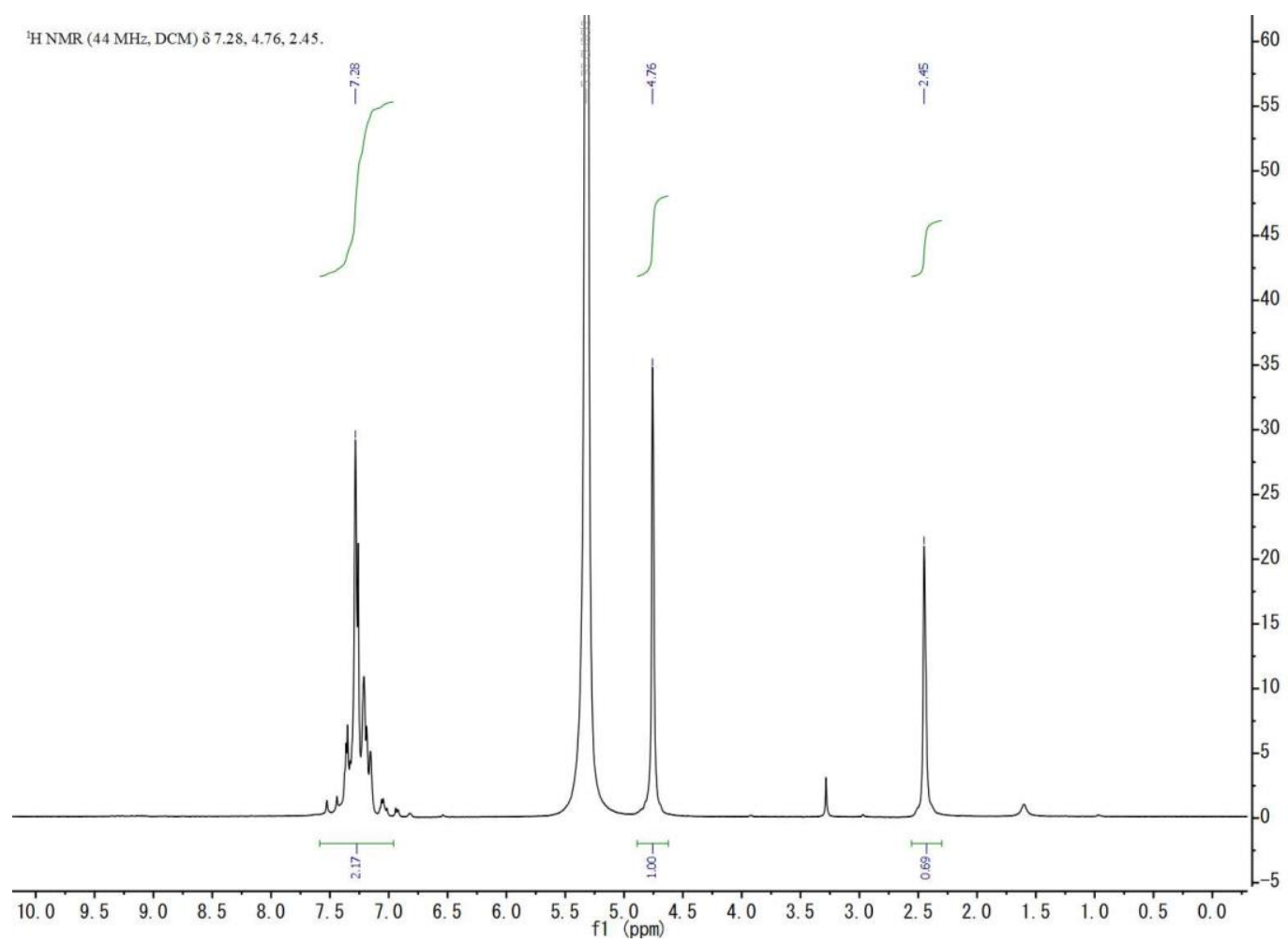

Figure S29. ${ }^{1} \mathrm{H}$ NMR corresponding to Manuscript Table 2 entry 6.

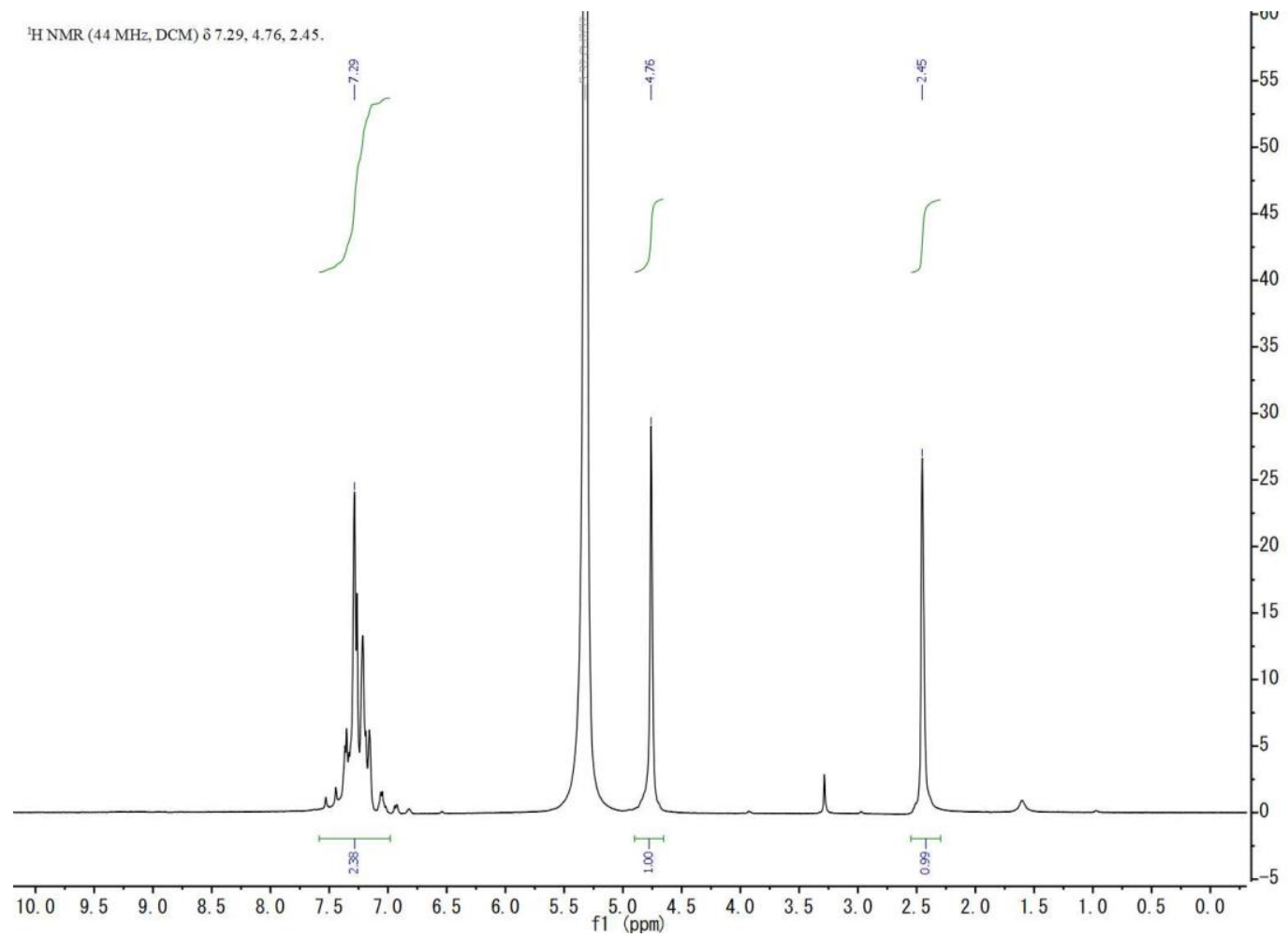

Figure S30. ${ }^{1} \mathrm{H}$ NMR corresponding to Manuscript Table 2 entry 7. 


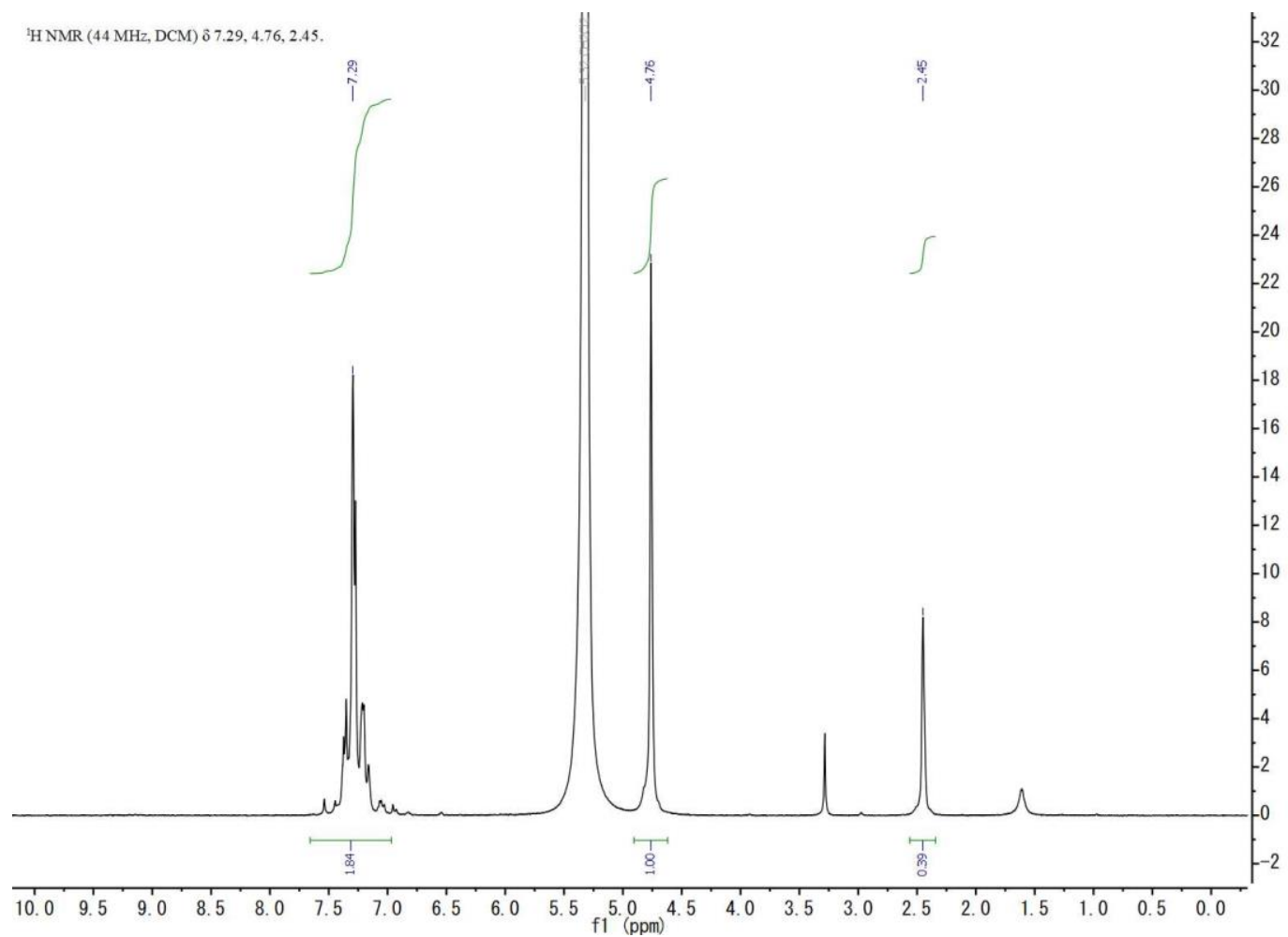

Figure S31. ${ }^{1} \mathrm{H}$ NMR corresponding to Manuscript Table 2 entry 8.

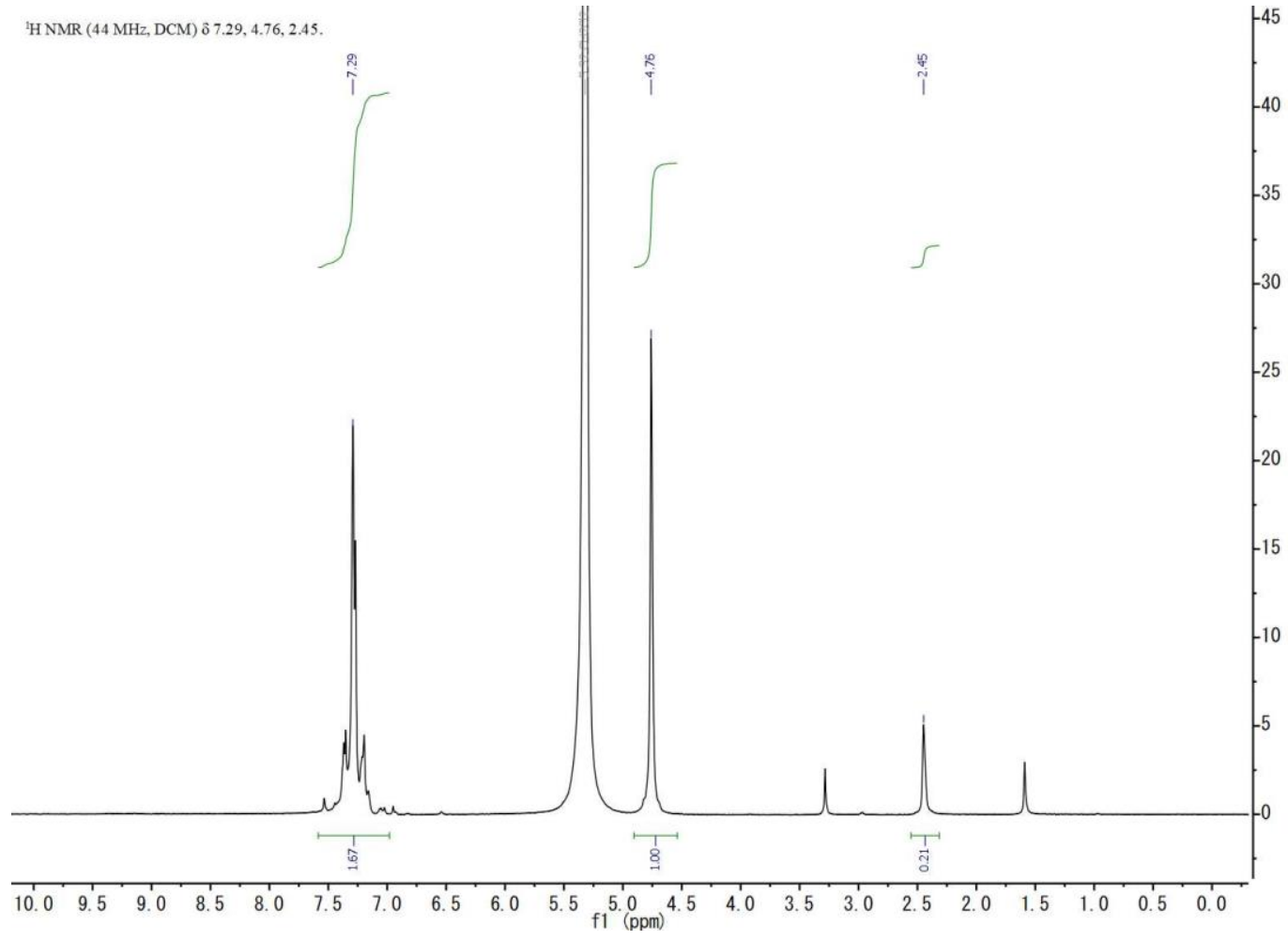

Figure S32. ${ }^{1} \mathrm{H}$ NMR corresponding to Manuscript Table 2 entry 9. 


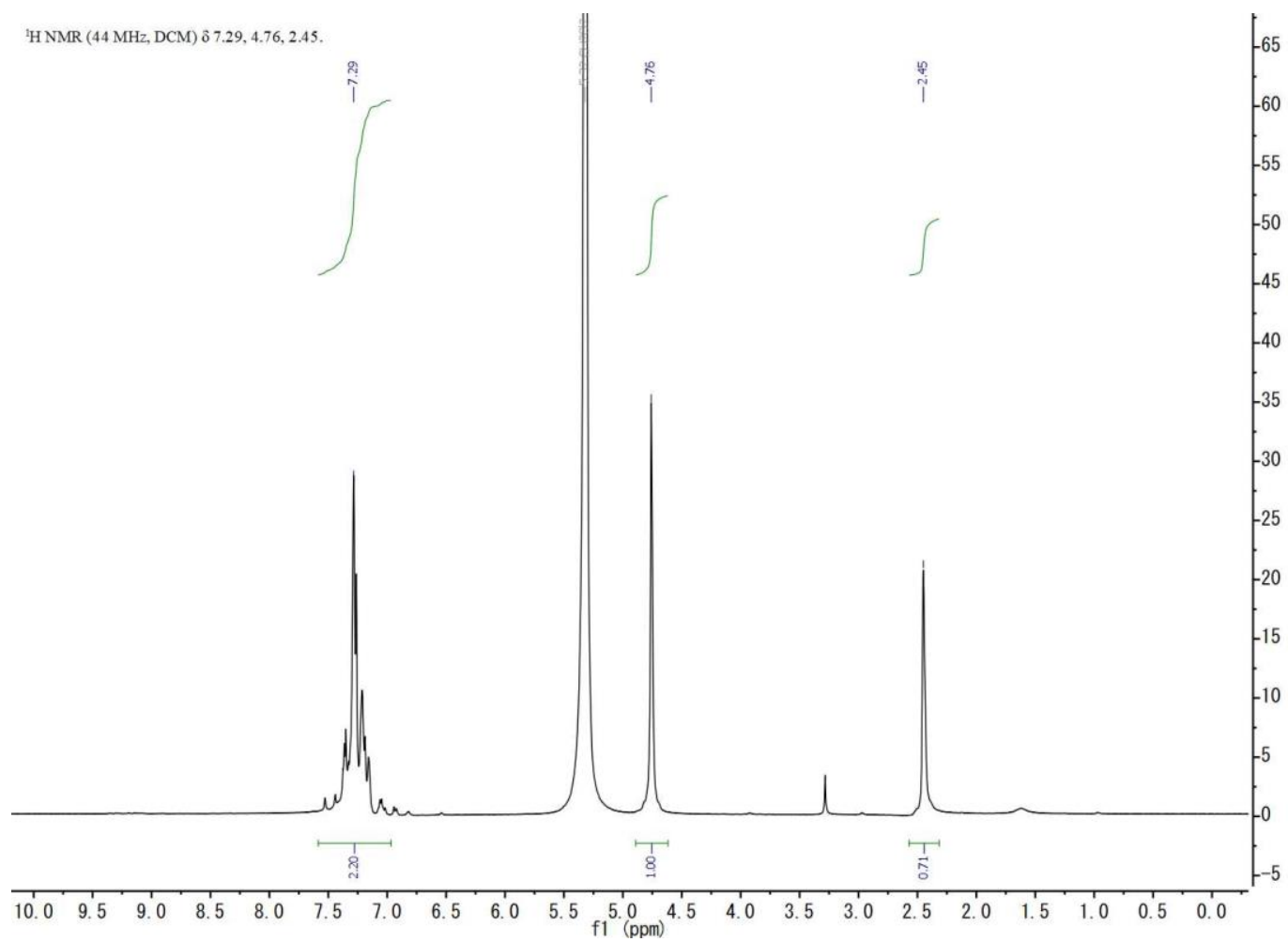

Figure S33. ${ }^{1} \mathrm{H}$ NMR corresponding to Manuscript Table 2 entry 10.

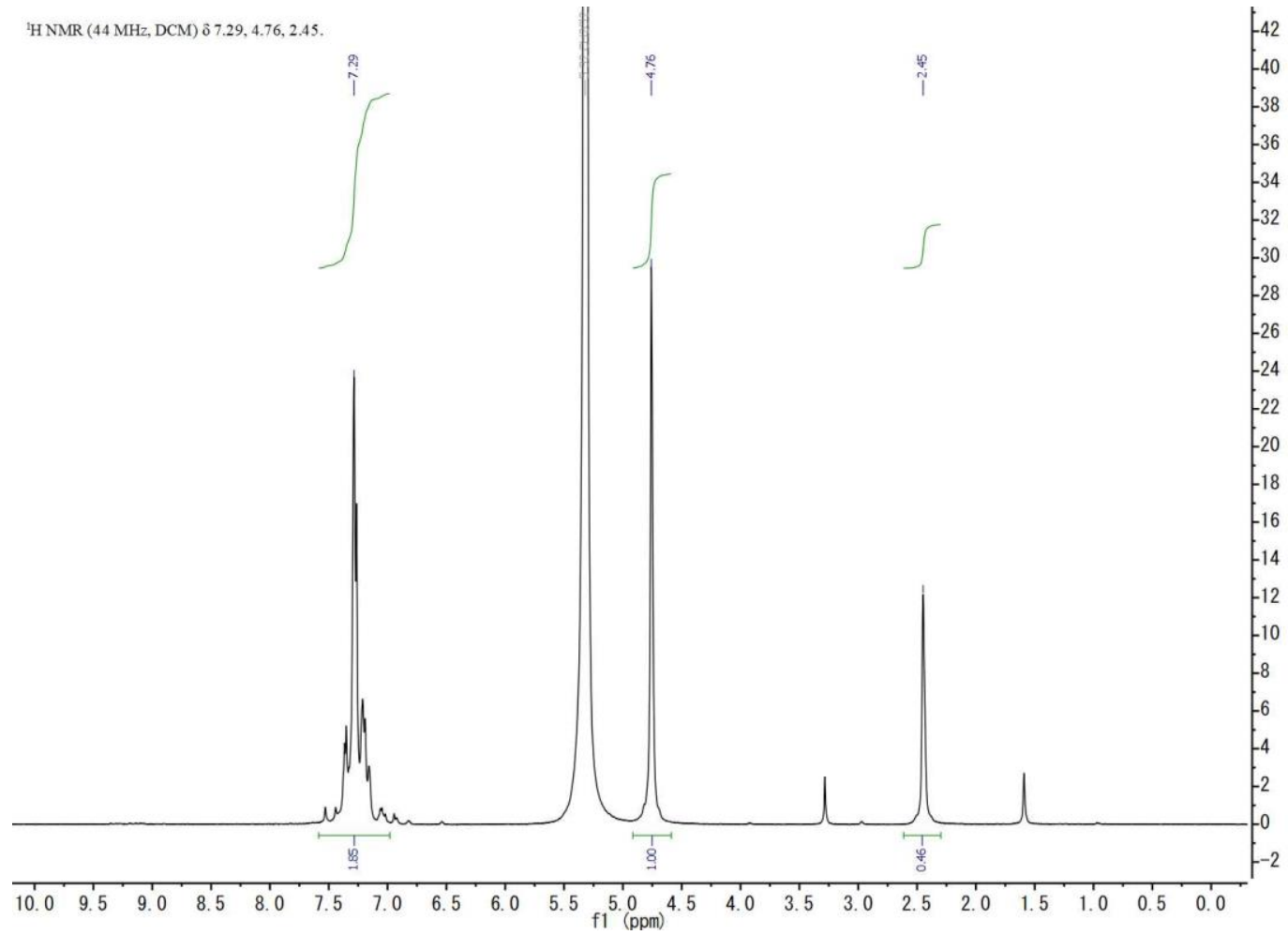

Figure S34. ${ }^{1} \mathrm{H}$ NMR corresponding to Manuscript Table 2 entry 11. 


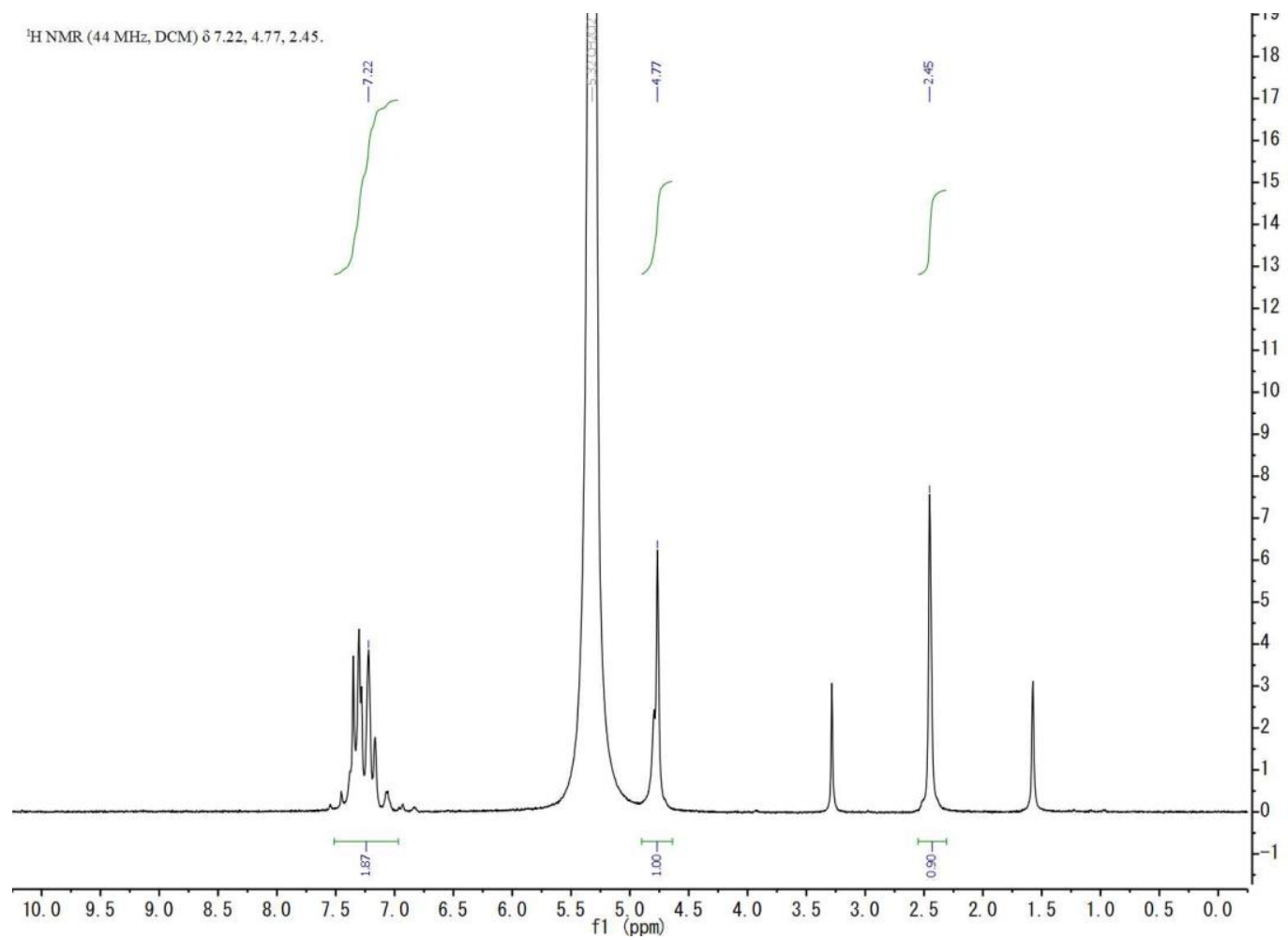

Figure S35. ${ }^{1} \mathrm{H}$ NMR corresponding to Manuscript Table 2 entry 12.

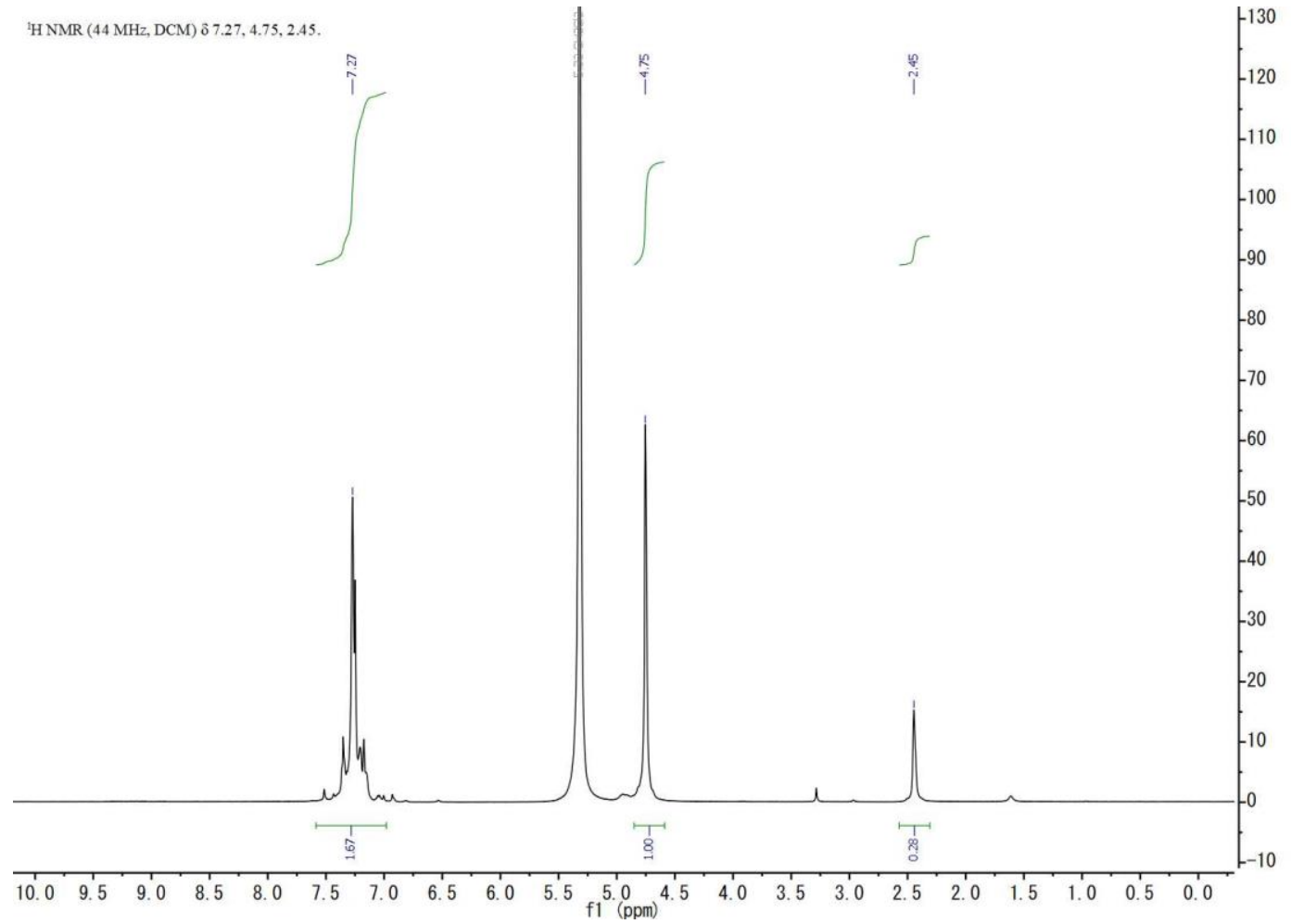

Figure S36. ${ }^{1} \mathrm{H}$ NMR corresponding to Manuscript Table 2 entry 13. 


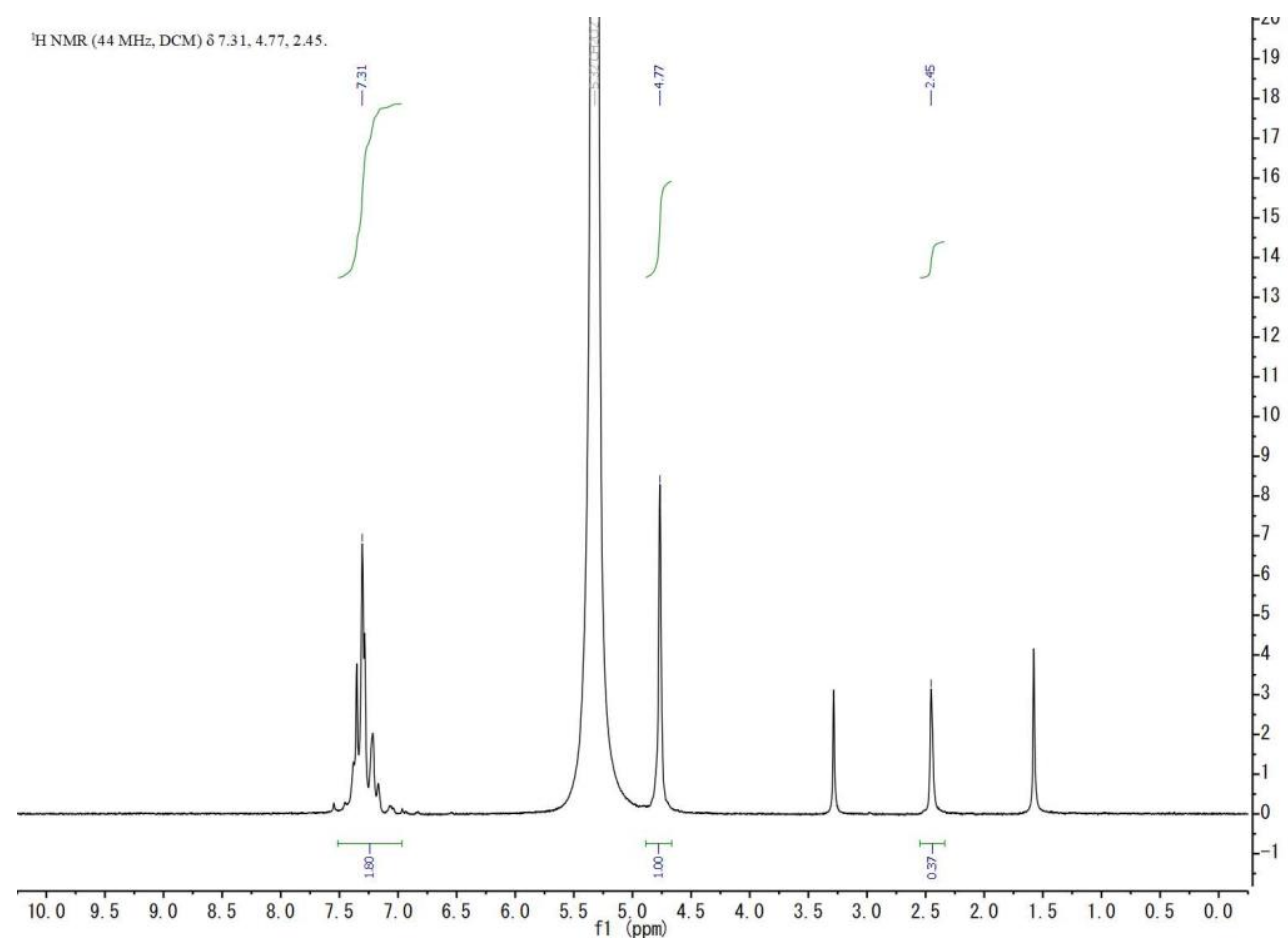

Figure S37. 'H NMR corresponding to Figure S18 entry "2 minutes".

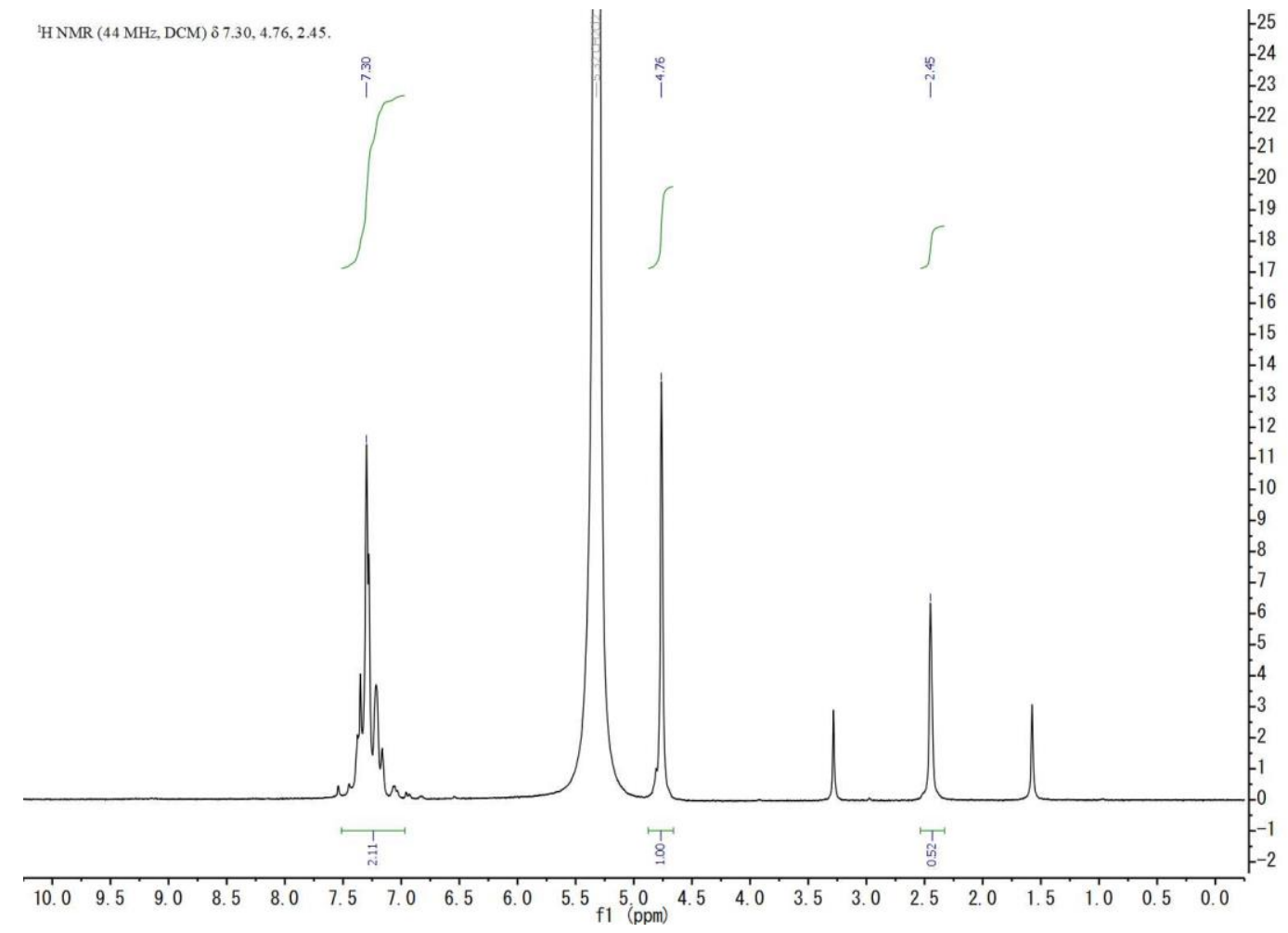

Figure S38. ${ }^{1} \mathrm{H}$ NMR corresponding to Figure S18 entry "4 minutes". 


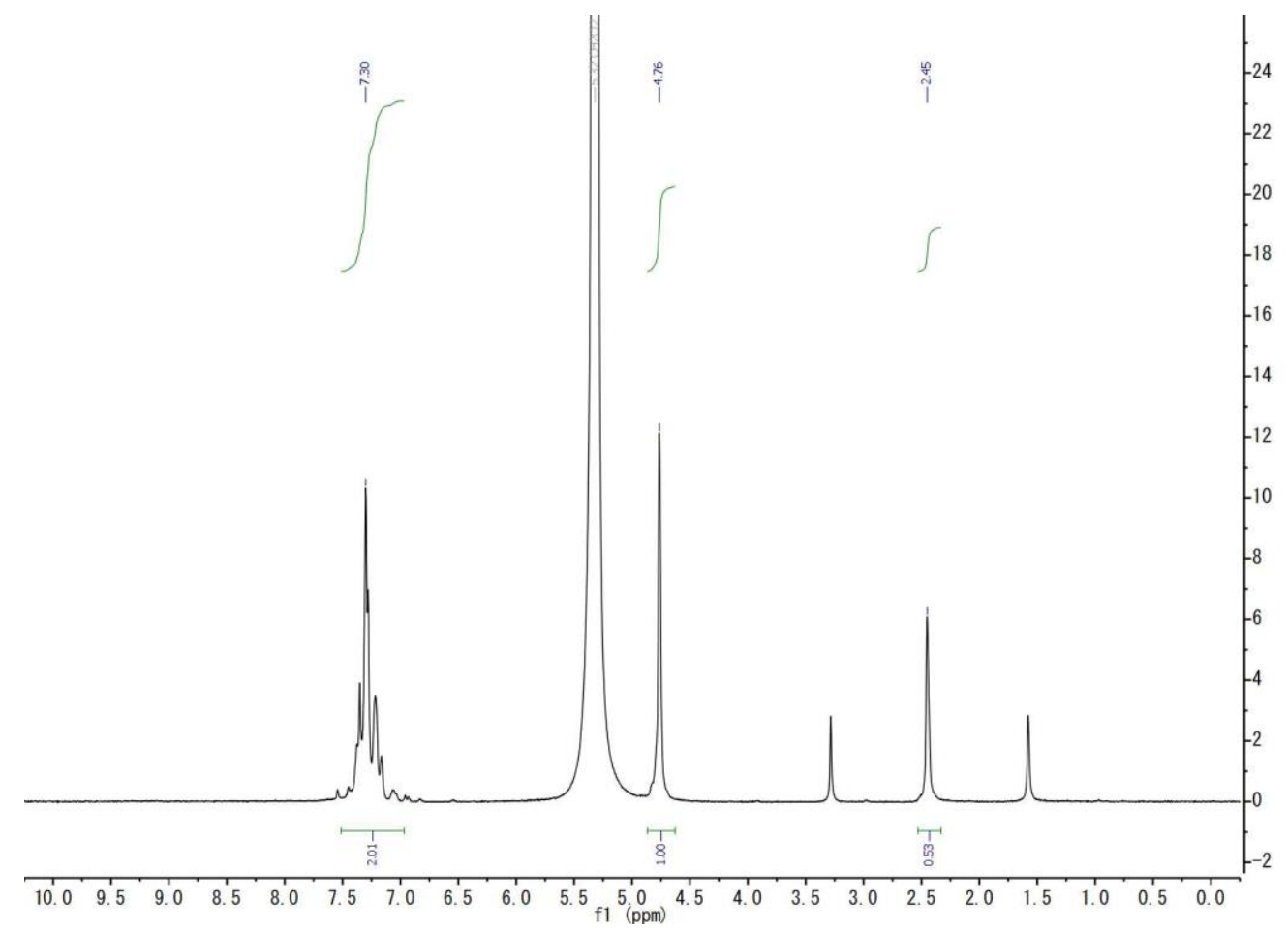

Figure S39. 'H NMR corresponding to Figure S18 entry “6 minutes”.

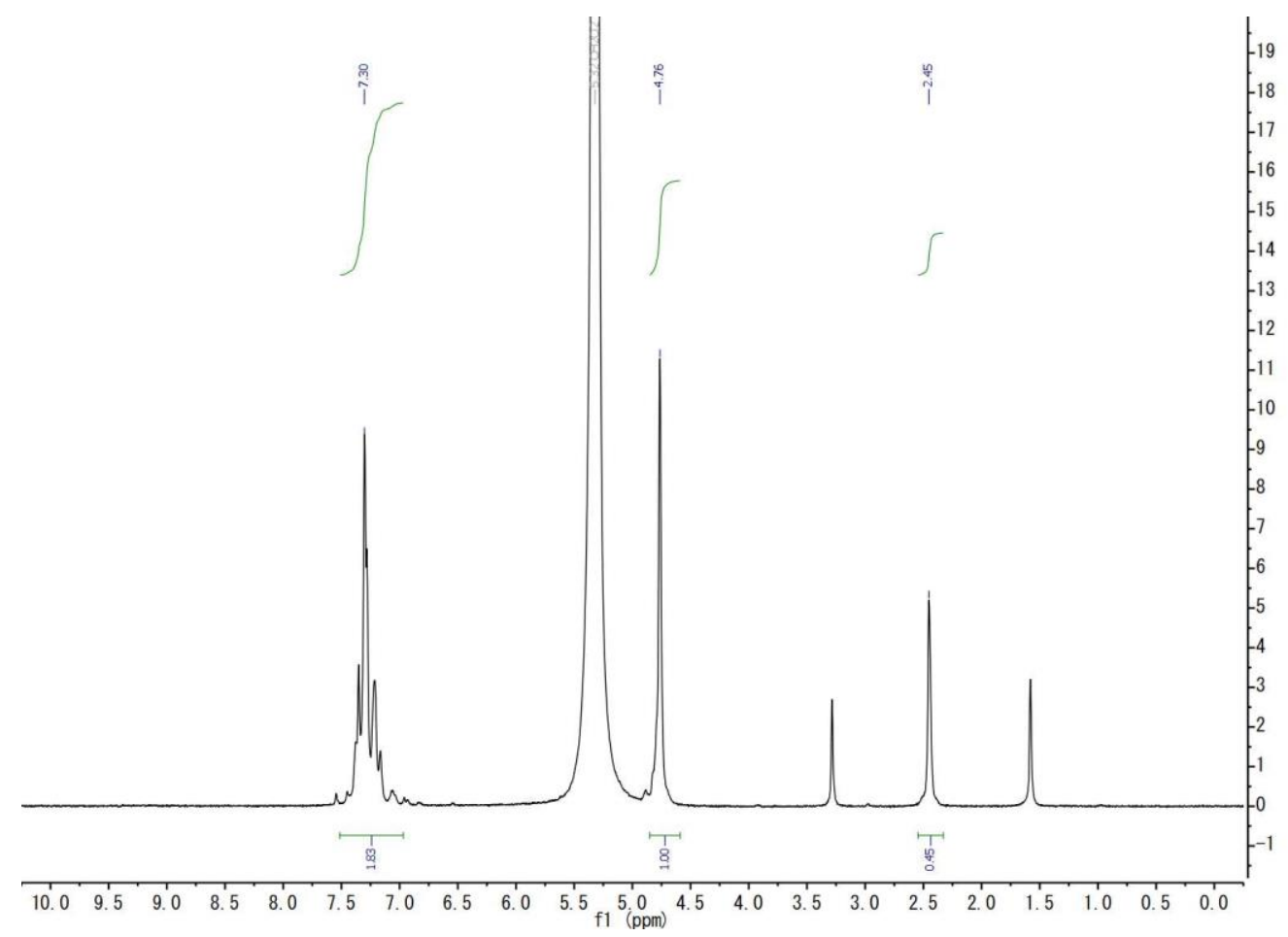

Figure S40. ${ }^{1} \mathrm{H}$ NMR corresponding to Figure S18 entry "7 minutes". 


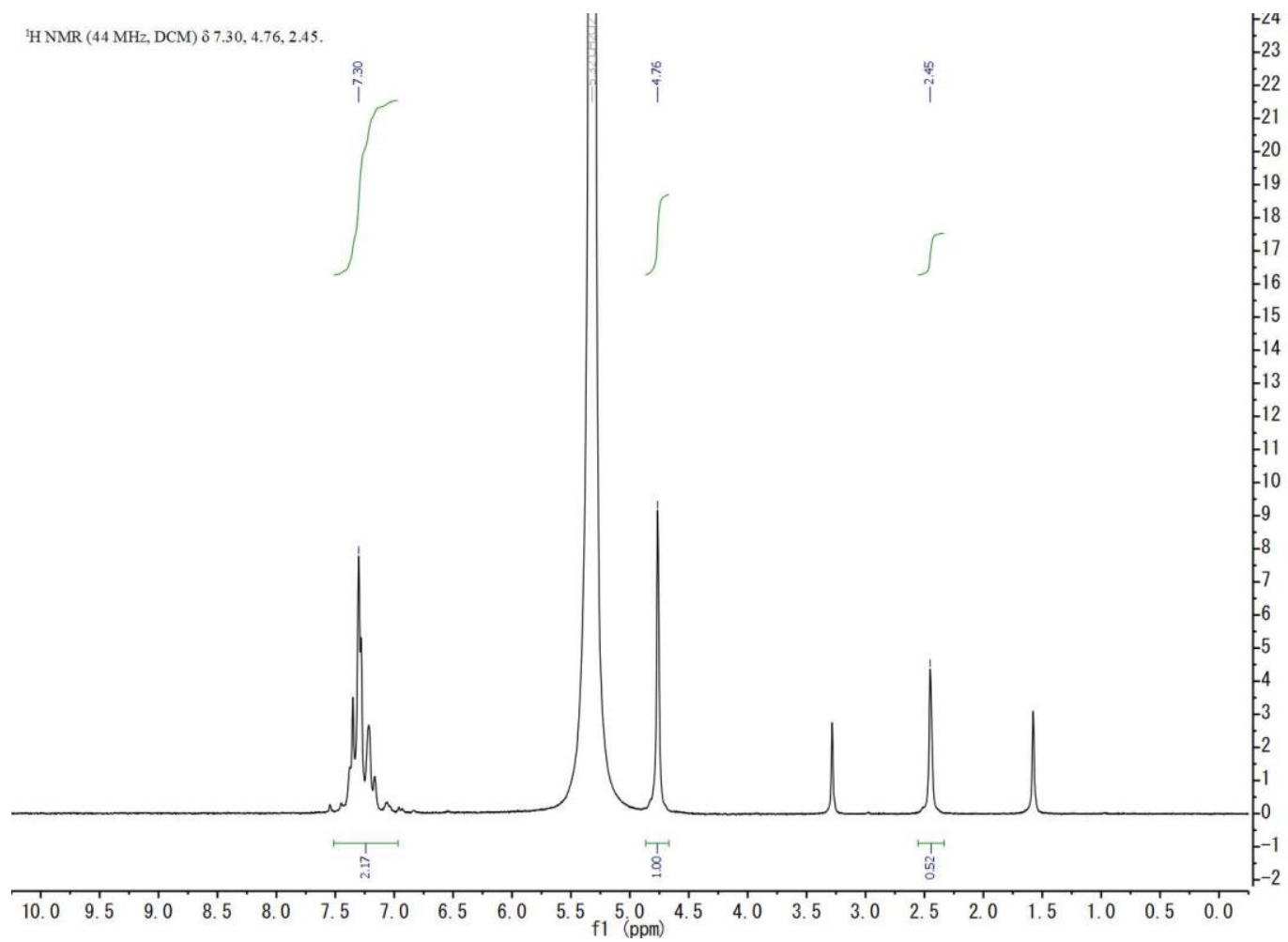

Figure S41. 'H NMR corresponding to Figure S18 entry "8 minutes".

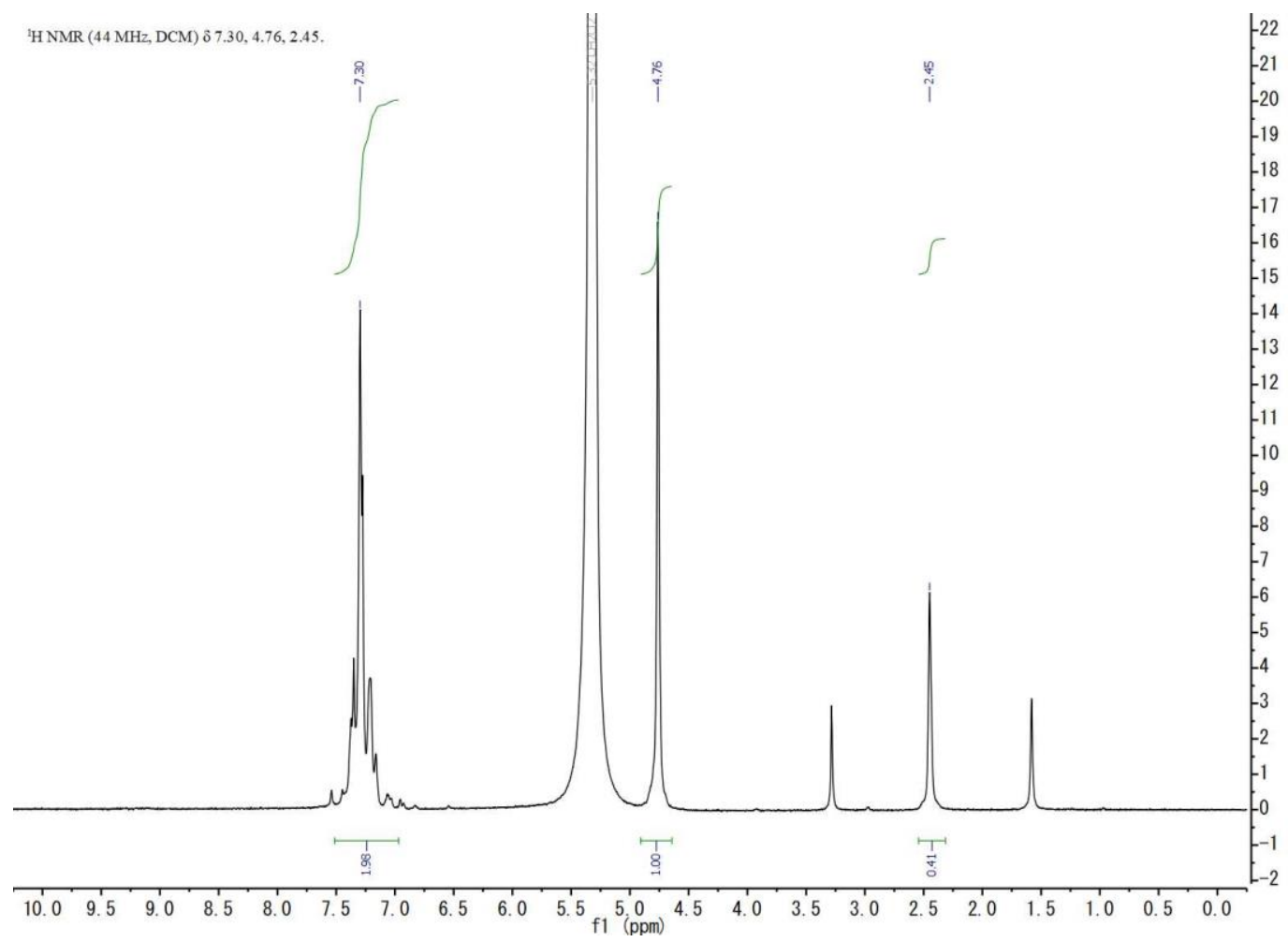

Figure S42. 'H NMR corresponding to Figure S18 entry "9 minutes". 


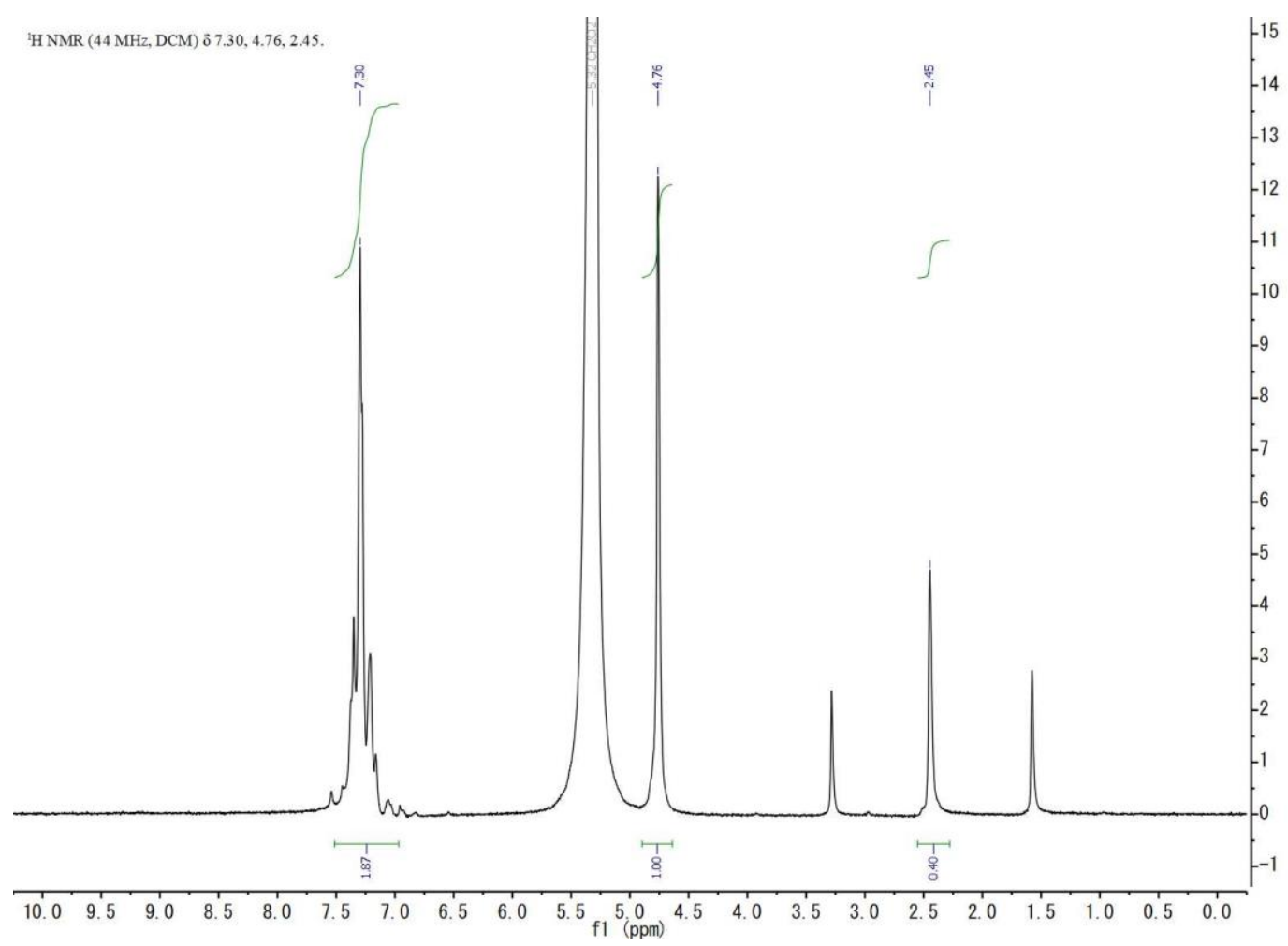

Figure S43. ${ }^{1} \mathrm{H}$ NMR corresponding to Figure S18 entry "10 minutes".

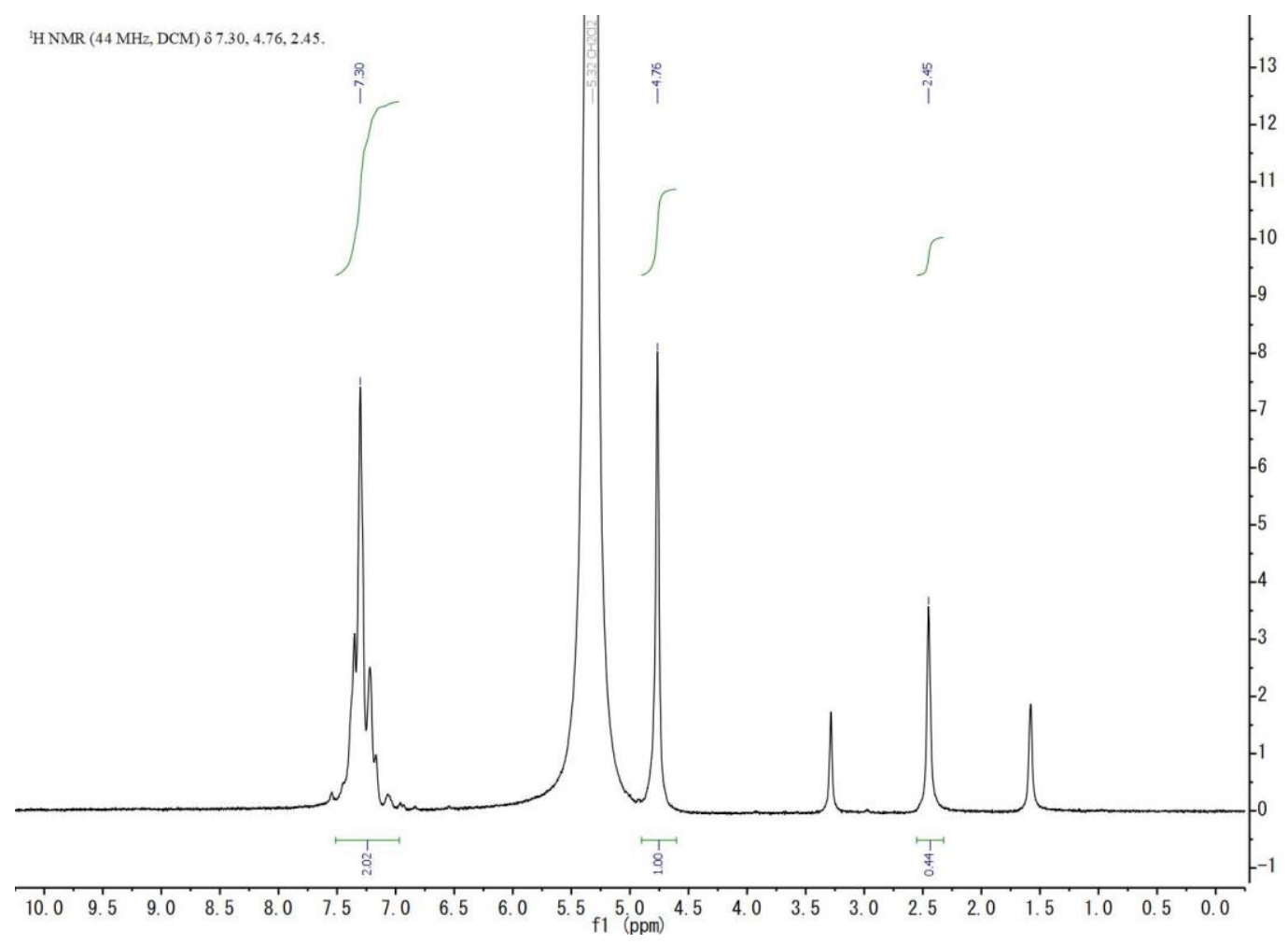

Figure S44. 'H NMR corresponding to Figure S18 entry "11 minutes". 


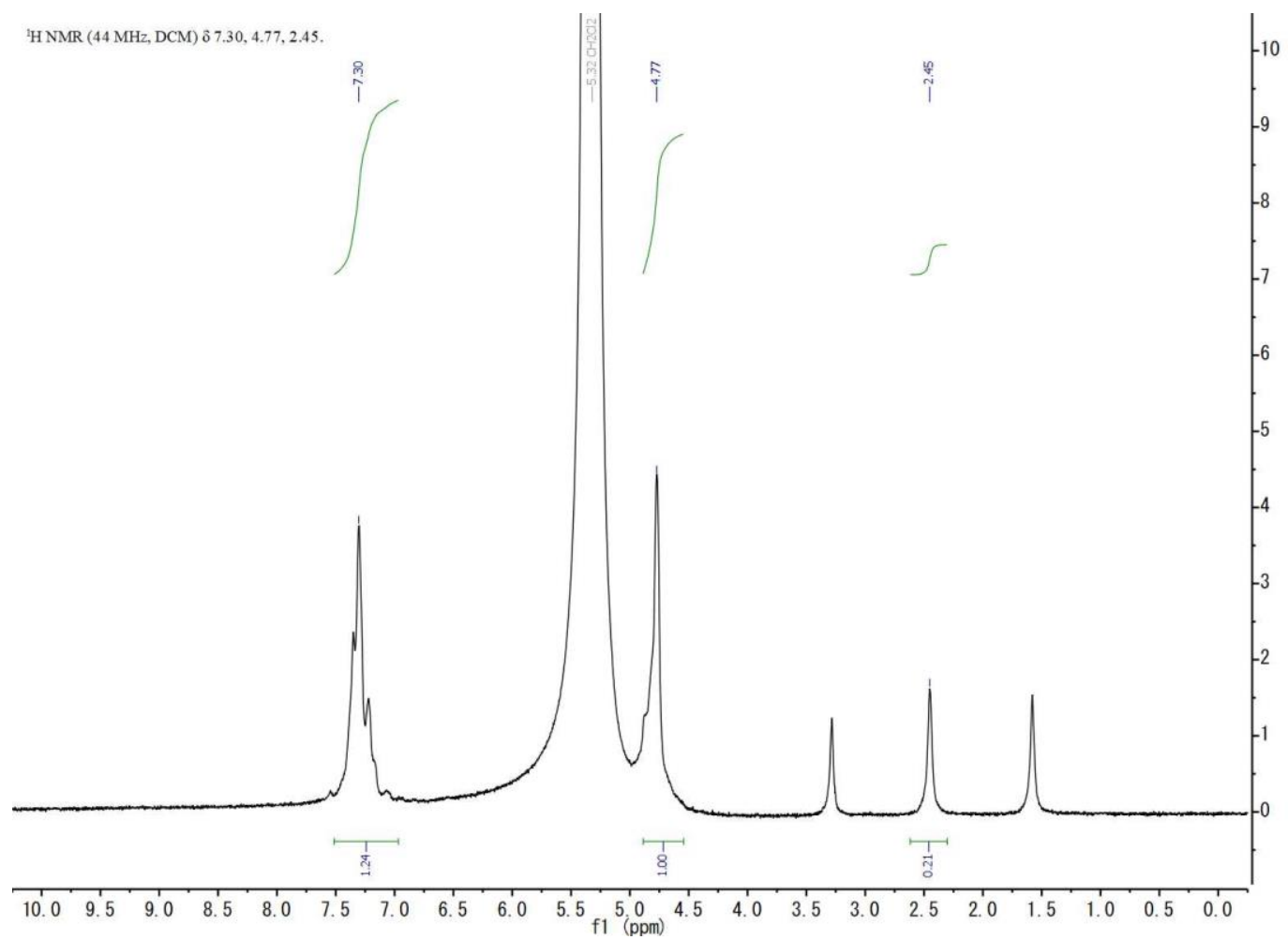

Figure S45. ${ }^{1} \mathrm{H}$ NMR corresponding to Figure S18 entry “12 minutes".

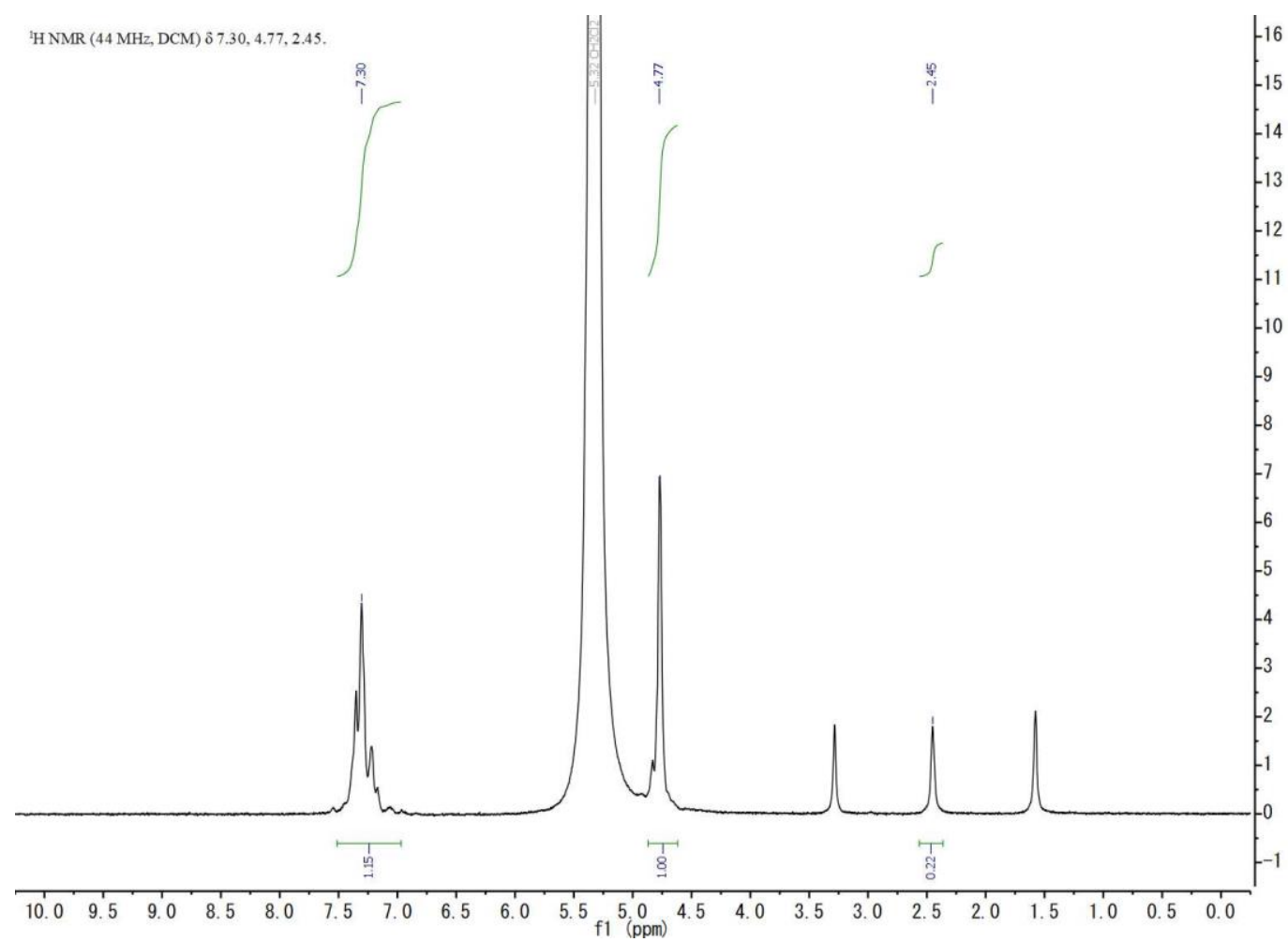

Figure S46. 'H NMR corresponding to Figure S18 entry "13 minutes". 


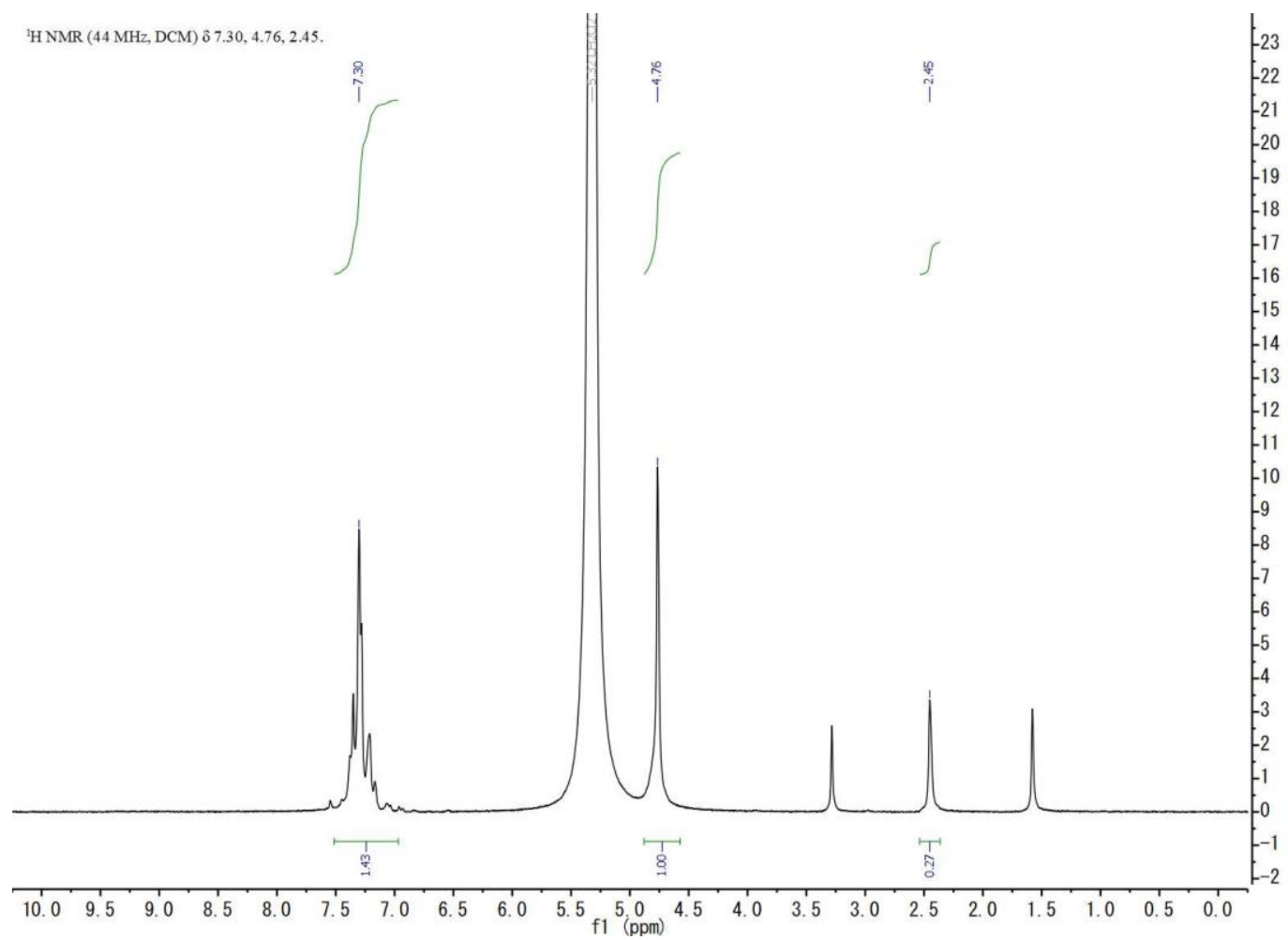

Figure S47. 'H NMR corresponding to Figure S18 entry "14 minutes". 


\section{References}

S1 Steiner, A.; Williams, J. D.; De Frutos, O.; Rincón, J. A.; Mateos, C.; Kappe, C. O. Continuous photochemical benzylic bromination using in situ generated $\mathrm{Br}_{2}$ : process intensification towards optimal PMI and throughput. Green Chem. 2020, 22, 448-454.

S2 Weast, R. C.; Astle, M. J.; Beyer W. H. Handbook of Chemistry and Physics; CRC Press: Boca Raton 1984.

S3 Blanksby, S. J.; Ellison, G. B. Bond Dissociation Energies of Organic Molecules. Acc. Chem. Res. 2003, 36, 255-263.

S4 Luo, Y.-R. Comprehensive Handbook of Chemical Bond Energies, CRC Press: Boca Raton 2007. 